\title{
Abrupt Alnus population decline at the end of the first millennium CE in Europe - The event ecology, possible causes and implications
}

\section{Latalowa, Malgorzata}

2019-08

Latalowa, M , Swieta-Musznicka, J , Slowinski , M , Pedziszewska , A, Noryskiewicz , A M , Zimny , M , Obremska , M , Ott , F , Stivrins , N , Pasanen , L , Ilvonen , L , Holmström , L \& Seppä , H 2019 , ' Abrupt Alnus population decline at the end of the first millennium CE in Europe - The event ecology, possible causes and implications ' , Holocene , vol. 29 , no. 8 , pp. 1335-1349 . https://doi.org/10.1177/0959683619846978

http://hdl.handle.net/10138/305085

https://doi.org/10.1177/0959683619846978

unspecified

acceptedVersion

Downloaded from Helda, University of Helsinki institutional repository.

This is an electronic reprint of the original article.

This reprint may differ from the original in pagination and typographic detail.

Please cite the original version. 


\section{The Holocene}

\section{Abrupt Alnus population decline at the end of the first millennium CE in Europe - the event ecology, possible causes, and implications}

\begin{tabular}{|c|c|}
\hline Journal: & The Holocene \\
\hline Manuscript ID & HOL-18-0223.R1 \\
\hline Manuscript Type: & Paper \\
\hline $\begin{array}{r}\text { Date Submitted by the } \\
\text { Author: }\end{array}$ & $n / a$ \\
\hline Complete List of Authors: & $\begin{array}{l}\text { Latałowa, Małgorzata; University of Gdansk, Plant Ecology } \\
\text { Święta-Musznicka, Joanna; University of Gdańsk, Plant Ecology } \\
\text { Słowiński, Michał ; Institute of Geography and Spatial Organization of } \\
\text { the Polish Academy of Sciences, Department of Environmental Resources } \\
\text { and Geohazards; } \\
\text { Pędziszewska, Anna; University of Gdansk, Plant Ecology } \\
\text { Noryśkiewicz, Agnieszka; Uniwersytet Mikolaja Kopernika w Toruniu, } \\
\text { Institute of Archaeology, Faculty of History } \\
\text { Zimny, Marcelina; Uniwersytet Gdanski, Faculty of Biology, Dept. of Plant } \\
\text { Ecology } \\
\text { Obremska, Milena; Polska Akademia Nauk, Institute of Geological } \\
\text { Sciences } \\
\text { Ott, Florian; Max-Planck-Institut fur Menschheitsgeschichte, ; Deutsches } \\
\text { Geoforschungszentrum Potsdam, } \\
\text { Stivrins, Normunds; University of Latvia, 7Department of Geography, } \\
\text { Faculty of Geography and Earth Sciences } \\
\text { Pasanen, Leena; Oulun Yliopisto, Research Unit of Mathematical Sciences } \\
\text { Ilvonen, Liisa; University of Oulu, Department of Mathematical Sciences } \\
\text { Holmström, Lasse; University of Oulu, Department of Mathematical } \\
\text { Sciences } \\
\text { Seppä, Heikki; University of Helsinki, Department of Geology }\end{array}$ \\
\hline Keywords: & $\begin{array}{l}\text { Alnus long-term population dynamics, climate change, ecological } \\
\text { disturbance, palaeoecology, pathogen outbreak, Phytophthora }\end{array}$ \\
\hline Abstract: & $\begin{array}{l}\text { The study, based on the examination of } 70 \text { published and unpublished } \\
\text { pollen profiles from Poland and supplementary data from the } \\
\text { surrounding regions, shows that an abrupt, episodic Alnus population } \\
\text { decline at the end of the first millennium CE was a much more } \\
\text { widespread event than has been previously reported, spanning large } \\
\text { areas of the temperate and boreal zones in Europe. The data from } \\
\text { Poland suggest that the decline was roughly synchronous and most likely } \\
\text { occurred between the 9th and } 10 \text { th centuries, with strong indications for } \\
\text { the } 10 \text { th century. The pollen data indicate that human impacts were not } \\
\text { a major factor in the event. Instead, we hypothesize that one or a series } \\
\text { of abrupt climatic shifts that caused floods and droughts at the end of } \\
\text { the first millennium CE could have initiated this ecological disturbance, } \\
\text { leading to a higher vulnerability of the alder trees to a pathogen }\end{array}$ \\
\hline
\end{tabular}


outbreak. Following current observations of the decline of alder stands in Europe due to a Phytophthora outbreak, we suggest that a similar process may have occurred in the past. This study provides insight into long-term alder (mainly A. glutinosa) dynamics in a condition of climate change and illustrates its great resilience, enabling the natural, successful regeneration of alder stands after critical diebacks if environmental conditions improve. Our finding that the Alnus pollen decline reflects a roughly synchronous event indicates that the decline could be used as an over-regional chronostratigraphic marker for 800$1000 \mathrm{CE}$ in pollen diagrams from a large part of the European Lowland.

\section{SCHOLARONE ${ }^{\text {M }}$ \\ Manuscripts}


1 Abrupt Alnus population decline at the end of the first millennium CE in Europe - the event 2 ecology, possible causes, and implications

3

4 5

Małgorzata Latałowa ${ }^{1 a^{*}}$, Joanna Święta-Musznicka ${ }^{1 b}$, Michał Słowiński², Anna Pędziszewska ${ }^{1 c}$, Agnieszka M. Noryśkiewicz ${ }^{3}$, Marcelina Zimny ${ }^{1 d}$, Milena Obremska ${ }^{4}$, Florian Ott ${ }^{5,6}$, Normunds Stivrins ${ }^{7,8}$, Leena Pasanen $^{9 a}$, Liisa Ilvonen ${ }^{10}$, Lasse Holmström ${ }^{9 b}$, Heikki Seppä ${ }^{11}$

${ }^{1}$ Laboratory of Palaeoecology and Archaeobotany, Department of Plant Ecology, Faculty of Biology, University of Gdańsk, ul. Wita Stwosza 59, 80-308 Gdańsk, Poland, Email: a) m.latalowa@ug.edu.pl, b) joanna.swieta-musznicka@biol.ug.edu.pl, c) anna.pedziszewska@biol.ug.edu.pl, d) marcelina.zimny@biol.ug.edu.pl, phone: a) phone: +48 58 5236113, b) +48 585236112, c) +48 585236111, d) +48 585236114, fax: +48 585236002

${ }^{2}$ Department of Environmental Resources and Geohazards, Institute of Geography and Spatial Organization, Polish Academy of Sciences, Twarda 51/55, 00-818 Warszawa, Poland; Email: michal.slowinski@geopan.torun.pl, phone: + 4822 6978848, fax: +48 226206221

${ }^{3}$ Institute of Archaeology, Faculty of History, Nicolaus Copernicus University in Torun, Szosa Bydgoska 44/48, 87-100, Toruń, Poland; Email: agnieszka.noryskiewicz@umk.pl, phone: +48 56 6112321, fax: +4856 6113974

${ }^{4}$ Institute of Geological Sciences, Polish Academy of Sciences, Twarda 51/55, 00-818 Warszawa, Poland; Email: mobremska@twarda.pan.pl, phone: +48 22 6978-805, fax: +48 226206223

${ }^{5}$ Section 5.2 - Climate Dynamics and Landscape Evolution, GFZ German Research Centre for Geosciences, Telegrafenberg, 14473 Potsdam, Germany; Email: florian.ott@gfz-potsdam.de ${ }^{6}$ Max Planck Institute for the Science of Human History, Department of Archaeology, Kahlaische Strasse 10, 07745 Jena, Germany, Email: ott@shh.mpg.de, phone: +49 (0) 3641 686-720, fax: +49 (0)3641 686-990

${ }^{7}$ Department of Geography, Faculty of Geography and Earth Sciences, University of Latvia, Jelgavas Street 1, Riga LV-1004, Latvia, Email: normunds.stivrins@1u.lv, phone: +371 67033935

${ }^{8}$ Department of Geology, School of Science, Tallinn University of Technology, Ehitajate tee 5, Tallinn 19086, Estonia, Email: normunds.stivrins@taltech.ee, phone: +372 620 3010, fax: +372 6202020

${ }^{9}$ Research Unit of Mathematical Sciences, University of Oulu, Pentti Kaiteran katu 1 Linnanmaa, PO. Box 8000, FI-90014 Oulu, Finland; Email: a) Leena.Ruha@oulu.fi, b) Lasse.Holmstrom@oulu.fi, phone: a) +358 29448 1833, b) +358 29 4481739, fax: +358 8344084

${ }^{10}$ Department of Mathematics and Statistics, University of Helsinki, PL 68 (Pietari Kalmin katu 5), FI00014 Helsinki, Finland, Email: liisa.ilvonen@,helsinki.fi, phone: +358 0294151506

${ }^{11}$ Department of Geosciences and Geography, University of Helsinki, PL 64 (Gustaf Hällströmin katu 2), 00014 HELSINGIN YLIOPISTO, Helsinki, Finland; Email: heikki.seppa@helsinki.fi, phone: 0294150820 
38 Corresponding author: Małgorzata Latałowa, ${ }^{1}$ Laboratory of Palaeoecology and Archaeobotany, 39 Department of Plant Ecology, Faculty of Biology, University of Gdańsk, ul. Wita Stwosza 59, 80-308

40 Gdańsk, Poland, phone: +48 58 5236113. E-mail: m.latalowa@ug.edu.pl

41

42

43 Abstract

44 The study, based on the examination of 70 published and unpublished pollen profiles from Poland and 45 supplementary data from the surrounding regions, shows that an abrupt, episodic Alnus population 46 decline at the end of the first millennium CE was a much more widespread event than has been 47 previously reported, spanning large areas of the temperate and boreal zones in Europe. The data from 48 Poland suggest that the decline was roughly synchronous and most likely occurred between the $9^{\text {th }}$ and $4910^{\text {th }}$ centuries, with strong indications for the $10^{\text {th }}$ century. The pollen data indicate that human impacts 50 were not a major factor in the event. Instead, we hypothesize that one or a series of abrupt climatic 51 shifts that caused floods and droughts at the end of the first millennium CE could have initiated this 52 ecological disturbance, leading to a higher vulnerability of the alder trees to a pathogen outbreak. 53 Following current observations of the decline of alder stands in Europe due to a Phytophthora 54 outbreak, we suggest that a similar process may have occurred in the past. This study provides insight 55 into long-term alder (mainly A. glutinosa) dynamics in a condition of climate change and illustrates its 56 great resilience, enabling the natural, successful regeneration of alder stands after critical diebacks if 57 environmental conditions improve. Our finding that the Alnus pollen decline reflects a roughly 58 synchronous event indicates that the decline could be used as an over-regional chronostratigraphic 59 marker for 800-1000 CE in pollen diagrams from a large part of the European Lowland.

Key words: Alnus long-term population dynamics, climate change, ecological disturbance, palaeoecology, pathogen outbreak, Phytophthora 
66

67

68

69

70

71

72

73

74

75

76

77

78

79

80

81

82

83

84

85

86

87

88

89

90

\section{Introduction}

Disturbances are widely recognized as one of the main factors influencing the direction and rate of forest succession in temperate and boreal biomes, where the forest composition is not only shaped by regional climate, soil, or topography but also frequently punctuated by more abrupt and less predictable factors, such as wildfires, storms, or pathogen outbreaks (Bradshaw and Sykes, 2014). Recently, the unprecedented rate of climate change predicted in for the 21 st century is considered a likely cause of a higher frequency of different catastrophic natural events (Mann et al., 2017), leading to the potential damage of forest stands (Kramer et al., 2008; Seidl and Rammer, 2017; Veraverbeke et al., 2017) and a higher risk of insect and pathogen outbreaks among several tree species (La Porta et al., 2008; Sturrock et al., 2011; Santini et al., 2013; Flynn and Mitchell, 2018).

To understand the role of disturbances in forest ecosystems, knowledge about their past occurrence and effects is important (Jeger and Pautasso, 2008; Cole et al., 2014). Among the most convincing evidence of past disturbances are abrupt declines in pollen values of specific tree taxa in pollen diagrams. However, a problem arises when trying to determine the disturbance agent that caused the decline based on sedimentary records. Only in the case of human impacts (Kitagawa et al., 2016; Wacnik et al., 2016), forest fires (Tinner et al., 2000; Yin et al., 2016), and sharp climatic shifts (Ammann et al., 2013; Ghilardi and O'Connell, 2013) is the causal attribution less complicated. Detecting past disturbances caused by beetle outbreaks, plant diseases, and storms is more difficult. Ascertaining the occurrence of past storms is practically impossible (but see, for example, de Jong et al., 2009; Kaniewski et al., 2016), while past beetle outbreaks have been traced in some cases using fossil beetle remains preserved in sediments (Girling and Greig, 1985; Clark and Edwards, 2004; Morris et al., 2015). Recently, progress has been achieved in analysing non-pollen palynomorphs from pollen samples, which in some cases have disclosed outbreaks of fungal pathogens (van Geel and Andersen, 1988; van Geel et al., 2013; Latałowa et al., 2013).

The complexity of this issue is well illustrated by the debates on a European-wide elm decline c. 6300 -5800 cal BP (Iversen, 1941; Troels-Smith, 1960; Peglar, 1993; Parker et al., 2002; Batchelor et al., 2014) and a hemlock decline c. 5500-5100 cal BP in eastern North America (Davis, 1981; Allison et al., 1986; Bennett and Fuller, 2002; Foster et al., 2006). In both cases, the conspicuous and abrupt decline of a single species was the subject of different hypotheses concerning a potential disturbance agent. Sudden climate change, a beetle or pathogen outbreak, and human impacts (in the 
case of Ulmus decline) were discussed as potential factors interacting separately or in combination

97

98

99

0100 (summarized by Waller, 2013).

Here, we develop our earlier finding that the episodic decline of Alnus at the close of the first millennium CE was a widespread phenomenon and not an effect of human impacts or the sole effect of climate change (Stivrins et al., 2017). We present pollen data from a larger region of Europe that show that the Alnus decline not only occurred in the Baltic countries, Finland, and western Russia but was also equally prominent and obvious in many locations in north-central Europe and that the geographic range of the event probably extended further to western Europe. Important pollen data from the event are provided by a new pollen diagram from an annually laminated lake sediment core from Lake Czechowskie in Poland. The sediments, which were analysed with high resolution for pollen and accurately dated based on the varve chronology, are used to identify the beginning, end, and duration of the event. In turn, the high-resolution analysis of pollen and non-pollen palynomorphs from peat-bog profiles serves to identify environmental changes around the decline. Finally, we discuss the potential causes of this event. Our study links a well-defined, large-scale ecological disturbance from the past with a very similar recent large-scale alder forest dieback in Europe, which is a great problem for nature protection and the management of riverine ecosystems (Jung et al., 2016).

\section{Study area and present-day Alnus occurrence}

The present study covers northern and central Poland between $52-55^{\circ} \mathrm{N}$ and $14-24^{\circ} \mathrm{E}$ (the northern part of the Central European Plain) (Fig. 1). The area belongs to the temperate climate zone of Europe and lies at the transition where the Atlantic and continental air masses clash. The continentality gradient increases from west to east. The climate is relatively warm and wet, with annual precipitation of 550$700 \mathrm{~mm}$ on average, annual mean air temperatures between 6.5 and $8.5^{\circ} \mathrm{C}$, average January temperatures between 0 and $-4^{\circ} \mathrm{C}$, and average July temperatures between 18 and $17^{\circ} \mathrm{C}$ (Lorenc, 2005).

Most of this area was covered by an ice sheet during the last glacial period. In the northern regions, the ice sheet and its meltwaters left, among other forms, ranges of terminal moraines dissected by a dense network of interconnected lake channels and river valleys. The hills of the moraines are higher than $300 \mathrm{~m}$ a.s.l. at their highest points. Flat or gently undulating ground moraine, which usually does not exceed $200 \mathrm{~m}$ a.s.l., is the main landscape element in central Poland. Patches of outwash plains and kame terraces are distributed throughout the region (Gilewska, 1991). Common features of such deglaciated environments are large lakelands and numerous mires of various origins that fill lake 
channels, river valleys, and kettle holes, providing perfect conditions for palaeoecological studies; therefore, a number of sites have been investigated here by means of pollen analysis.

Large proportions of wetlands in the study area are habitats for riparian alder-elm forests (Alno- 
Black alder is one of the most common species, and grey alder is distinctly less frequent in the

The pollen data selected for this study derive from original publications, data stored in the European Pollen Database (EPD, www.europeanpollendatabase.net), and in a few cases, from unpublished materials provided by the study authors (ESM Table S1, available online). The suitability of a pollen profile for examination of the presence/absence of the Alnus decline was determined according to the stratigraphic resolution of pollen sampling in the section under concern. In addition to the pollen percentage values, we used the pollen influx data (pollen accumulation rate) from three sites to explore the decline of the Alnus population in more quantitative terms.

Seventy one pollen profiles ( $6 \underline{9} 8$ sites) were included in this paper. The basic information concerning their geographical position, category, dating methods and results, Alnus decline characteristics, and references are included in ESM Table S1 (available online). The metadata for each site, such as the basin type (lake or peat-bog), its surface, the presence of an inlet or outlet, the distance to a river valley, and potential habitats for Alnus, are consolidated in ESM Table S2 (available on-line). Selected palaeoenvironmental data on local hydrological changes at the event, human impacts, and pollen data from the main tree taxa are provided in ESM Table S3 (available online).

The sites were grouped into two categories. The "primary sites" (A) category includes $\underline{31}$ profiles with high pollen sampling resolution and age/depth models based on a series of radiocarbon dates in the section of interest or with ${ }^{14} \mathrm{C}$ dates related directly to the Alnus decline event. New age/depth models were developed based on the radiocarbon dates listed in original publications and using the current calibration curve (Reimer et al., 2013) and OxCal software (version 4.2; Bronk Ramsey and Lee, 2013). The most precise dating has been provided for the record from annually laminated sediments in Lake Czechowskie, Lake Żabińskie and Lake Szurpiły_-_where the chronological information is based on atmultiple dating approaches (Wulfet al., 2016). The Lake Czechowskie chronology is based on varve counting, tephrochronology, AMS ${ }^{14} \mathrm{C}$ dating on terrestrial plant remains, in-situ ${ }^{10} \mathrm{Be}$ and ${ }^{137} \mathrm{Cs}$ activity meauserments; the chronological uncertainty for the 
period around $1000 \mathrm{CE}$ does not exceed \pm 10 varve years (Czymzik et al., 2018; Ott et al., 2016; Wulf et al., 2016). In Lake Żabińskie

different methods of varve counting, AMS ${ }^{14} \mathrm{C}$ dates, ${ }^{137} \mathrm{Cs}$ activity and cryptotephra were used to establish the sediment chronology; in this case the averaged chronological uncertainty in the section under concern was calculated to ${ }^{+12}$-24 varve years (Żarczyński et al., 2018, 2019). The Lake Szurpiły chronology was established by using different methods of varve countig and independent radiometric dating (AMS ${ }^{14} \mathrm{C},{ }^{210} \mathrm{~Pb}$ and ${ }^{137} \mathrm{Cs}$ ); the dating uncertainty in the section around the Alnus decline is \pm 42 varve years (Kinder et al., 2013; Kinder, oral inf.).

The "secondary sites" (B) are those of weaker quality concerning their independent chronologies. In $40 \%$ of the sites, the Alnus decline was dated to approximately the $9^{\text {th }}-10^{\text {th }}$ centuries according to the indirect premises (ESM Table S1, available online); the main comparison was with the nearest well-dated pollen profiles and a cross-check of the palynological indications of the human occupation phases with knowledge of the chronology of a nearby early medieval settlement development. These kinds of data did not add to the establishment of the exact timing and duration of the decline but did enable the identification of Alnus events recorded in particular profiles as roughly concurrent with those at other sites.

The statistical significance of the decline was analysed using 11 Alnus pollen curves selected on the basis of their relatively high temporal resolution. We used SiZer analysis (Significant Zero crossings of derivatives) (Chaudhuri and Marron 2000) to detect significant declines and rises in the Alnus population. SiZer analysis has been shown to be a powerful tool in ecology to detect the significant change points in time series data inferred as ecological thresholds (Sonderegger et al., 2009; Clements and Rohr, 2009; Clements et al., 2010). When applied to time series, SiZer analysis applies a nonparametric smoothing to a signal and detects the time intervals where the smooth is significantly increasing or decreasing. A wide range of smoothing levels are considered to reveal the salient features in the signal at all time scales. When compared to many other change point detection methods, the strength of the SiZer analysis is in its flexibility. It allows for a trend in the data, the detection of multiple change points and changes in the temporal sampling distribution, and adapts to temporal changes in the error variance of the signal. The results of SiZer analysis are visualized using a colour map where the time is on the horizontal axis and the smoothing level is on the vertical axis, and for each pixel, its colour represents the significance of the derivative of the smooth for the corresponding time point and scale. A SiZer map is an efficient tool that helps discover all the significant declines and 
rises in the data at a glance (ESM Figure 1, available online). The SiZer analyses were performed with the SiZer package (Sonderegger, 2012) in R 3.1.2 (R Development Core Team, 2014).

To illustrate the Alnus decline in a broader context of environmental changes reflected by palynological data and to show that the decline is distinct irrespective of the site type, local conditions and pollen representation of human activity, we present two sample sets of pollen diagrams from lakes (Fig. 2) and peat bogs (Fig. 3); the sites strongly differ with respect to their surface size, which indicates different source areas of pollen (cf. Prentice, 1985; Sugita, 1993), and are located along the $600 \mathrm{~km}$-long W-E transect running through different geographic and historical regions of northern and central Poland.

\section{Results}

\section{Characteristics, statistical significance and chronology of the Alnus pollen decline}

The Alnus pollen curve decline is one of the striking features in the early medieval sections of many profiles in Poland (Fig. 1; ESM Table S1, available online). In $85 \%$ of the 710 pollen diagrams considered in the present study, the decline was abrupt, with the magnitude ranging from 40 to $90 \%$ reductions from pre-decline levels. Sharp declines were also displayed in the Alnus pollen influx values (pollen accumulation rates - PAR) calculated in three profiles: Lake Czechowskie (from c. 12000 to 2000 grains cm-2 $\mathrm{a}^{-1}$ ), Lake Suminko (from c. 6000 to 1800 grains $\mathrm{cm}^{-2} \mathrm{a}^{-1}$ ) (Fig. 2), and Bagno Kusowo (from c. 1800 to 400 grains $\mathrm{cm}^{-2} \mathrm{a}^{-1}$ ) (Fig. 3). The decline was distinct in both the lake sediment and peat-bog profiles (Figs. 2, 3 and 4). The review of the pollen diagrams in terms of the presence/absence of the event versus environmental factors such as basin morphometry and some features of the catchment showed no correlation (ESM Table S2, available online). The detailed characteristics of the Alnus pollen decline differed among the sites mostly because of the different sediment thicknesses and the different sampling resolutions in the relevant parts of the profiles. It seems that the weak expression or absence of the decline was (in most cases) caused by lower sampling resolution with respect to the sedimentation rate or sediment loss in the section of the pollen profiles of concern. In fact, in many profiles, a clear lithological limit occurred around the decline (ESM Table S3, available online).

The results of the SiZer analyses (Fig. 5, ESM Figure S1, available online) from 11 sites highlight all the significant decline-rise events in the Alnus curves during the last 2000 years. They show that a statistically significant decline was followed by a statistically significant rise at the end of the first millennium in eight of the 11 analysed time series. The sampling density in Białowieża 314D 
and 131C, and in Bukrzyno was too low, which hampered the detection of the Alnus decline so that

250 even the lowest values were observed at the end of the first millennium; the result was not statistically significant. Furthermore, two other statistically significant decline-rise events were detected in the Czechowskie and Racze records around the $4^{\text {th }}-5^{\text {th }}$ century and then around the $15^{\text {th }}$ century. The earlier, minor shift, although not statistically significant, was also detectable in some other sites.

Due to the annually laminated sediments and the high sampling resolution, the record from Lake Czechowskie (Fig. 2) offered-The most precisebest chronology for the early medieval event is available for the lakes with annually laminated sediments (Table 1). In Lake Czechowskie (Fig. 2)At this site, the Alnus values were 14\% until the decline began at $970 \mathrm{CE}$. The decline was extremely abrupt, so that by $1020 \mathrm{CE}$, the Alnus percentages were down to a minimum of $1.7 \%$, where they stayed until a rise began at $1090 \mathrm{CE}$, reaching over $10 \%$ by $1120 \mathrm{CE}$., which is practically the same level as before the decline. Thus, in the Lake Czechowskie record, the event lasted approximately 150 years. In Lake Żabińskie the Alnus curve declined by $870 \mathrm{CE}$ to $1.7 \%$ between 920 and $1000 \mathrm{CE}$, a rise began by $1060 \mathrm{CE}$ and by $1090 \mathrm{CE}$ the Alnus curve reached 11\% (Żarczyński et al., 2019). Considering relatively large dating uncertainty ( \pm 42 varve years), similar results were obtained in Lake Szurpiły (Kupryjanowicz and Fiłoc, 2016; Kupryjanowicz, unpubl. data). In this site the decline started at 830 CE, the minimum of $2.4 \%$ was reached at $930 \mathrm{CE}$, and already by $980 \mathrm{CE}$ the Alnus pollen curve started to rise reaching $10.5 \%$ at by $1010 \mathrm{CE}$.

Similar data have been obtained from other lake and bog profiles in which this event was dated using age/depth models based on radiocarbon dates ("primary sites") or according to the AMS ${ }^{14} \mathrm{C}$ dates for plant remains selected directly from the Alnus decline level (Table 1, ESM Table S1, available online). Keeping in mind the differences in the pollen sampling resolution in particular profiles and the large range of dating uncertainty, the ages (median) calculated in the individual profiles based on the age/depth models were surprisingly consistent, ranging from 800 to $970 \mathrm{CE}$ for the start of the decline, from 900 to $1020 \mathrm{CE}$ for the minimum values, and from 1040 to $1210 \mathrm{CE}$ for the full recovery of the Alnus pollen curve. According to these data, the whole period from the decline to the recovery lasted for 150 to 330 years in the individual sites, giving an average of 250 years. The collection of 30 radiocarbon dates from 20 sites performed specifically for the Alnus decline (Table 1) offered important support for an even more detailed determination of the age of the event. In most sites, the dates (median) for the Alnus pollen curve depression point to the $10^{\text {th }}$ century, which is in agreement with the age calculated from the annually laminated sediments.-of Lake Czechowskie. 
In only a few sites, the dates for the major Alnus decline in the first millennium CE estimated according to the published original data were older (ESM Table S1, available online). The earliest decline (c. $5^{\text {th }}-6^{\text {th }}$ centuries) was recorded in the Wojnowo site (Wacnik et al., 2012); this decline roughly coincides with the first statistically significant Alnus declines in Lake Czechowskie and Lake Racze and with the additional negative shifts preceding the main Alnus decline in some other sites (Fig. $5)$.

\section{The Alnus pollen decline vs. indicators of human impact}

The relationship of the Alnus pollen decline to the palynological indicators of settlement activity varied among the sites (Figs. 2 and 3, ESM Table S3, available online). In the majority of the sites, it was slightly preceded by the decline of some other tree pollen and the initial rise of pollen typical of the human land occupation phase. Such a situation is illustrated by the diagrams from Lake Suminko (Fig. 2) and Słowińskie Błota/85 (Fig. 3), for example, where already in the section preceding the Alnus fall, Carpinus and Quercus started to decline, the frequency of Poaceae, meadow plants and fallow indicators (P. lanceolata) and some weed pollen (Artemisia, Rumex acetosa/acetosella t.) slightly increased and the scattered pollen of cereals was present. In Lake Mełno (Fig. 2), an abrupt Alnus decline was preceded by a strong Carpinus decrease and distinctly increasing pollen curves of anthropogenic indicators, including cereals. In some sites, such as Lake Zarańskie (Fig. 2), the decline of Alnus pollen occurred in the already advanced human impact phase confirmed by cereal and $P$. lanceolata pollen, both exceeding $1 \%$.

There are also a few profiles in which the clear signature of the Alnus decline does not coincide with the indicators of settlement development. In the peat profiles from Białowieża Forest (Fig. 3), only weak negative shifts of the pollen curves of other deciduous trees (mainly Carpinus and Ulmus) occurred, and a few scattered pollen grains of anthropogenic indicators appeared at this level. In Lake Czechowskie, pollen evidence for human activity was very weak throughout the whole section of the profile (Fig. 2); moreover, at the Alnus decline level, cereal pollen entirely disappeared, while pollen of other taxa typical of human-made habitats was scarce. In contrast to other trees, in most sites, Alnus pollen curves regained their earlier levels, rising with increasing proportions of indicators of human impacts.

The relation of the Alnus decline to the frequency of microscopic charcoal particles found in some of the profiles did not show any consistent results either (Figs. 2 and 3). In Białowieża Forest, the 
311

312

313

314

10315

11

12316

13

14317

15318

16

17319

18

19320

20

charcoal particles declined in two profiles and rose in one. In Lake Czechowskie, their proportions decreased immediately at the Alnus decline and then rose again. In Bagno Kusowo, we observed the opposite pattern, while in Lake Suminko, the charcoal frequency did not change.

\section{The Alnus pollen decline vs. indicators of hydrological shifts}

The palaeoecological data point to hydrological shifts around the Alnus decline in all the peat profiles and in some lakes (Fig. 3, ESM Table S3, available online); however, the record of the hydrological changes in the peat bogs is much clearer than in the lake sediments. Only in a few shallow lakes (sites 3, 15, 22, 26 and 63 in ESM Table S3, available online), the lithological limits indicated distinct water level lowering. In deeper and larger lakes, the composition of the sediments did not show any clear change or display increases in mineral matter and changes in algae remains, which may have been the result of different factors, including water table lowering but also increased denudation and/or higher productivity caused by anthropogenic eutrophication or a warmer climate. The same explanation may underlie the discrete change in lithology in Lake Suminko (Fig. 2), where delicate, unclear lamination was present below the Alnus decline but disappeared entirely above it.

Changes in the hydrological conditions in the peat bogs are shown by examples presented in Fig. 3. In the profiles from Białowieża Forest (CE Poland), the decline in Botryococcus and Cyperaceae was followed by small peaks of Ledum and Entophlyctis lobata (BIA/314D) and Calluna (BIA/318C) and then a strong increase in Sphagnum. In Czerlon, a distinct shift from minerotrophic to ombrotrophic conditions was punctuated by a decline of Cyperaceae and Botryococcus, which were substituted by raised bog taxa: Sphagnum spores strongly increased while testate amoeba, such as Amphiterma wrightianum, Archerella flavum, Assulina spp., Heleopera sp., and Hyalosphenia papillo appeared concurrently with a depression in the Calluna pollen curve and then declined. Similar results have been obtained in the profile from Słowińskie Błota/85 (NW Poland), where a thin layer of Eriophorum vaginatum concurrent with a peak of Calluna and a deep depression in Sphagnum occurred immediately before the alder decline, indicating a dry spell. At the decline, the proportions of Sphagnum spores rose abruptly; at this level, A. flavum, Assulina spp., and Arcella discoides appeared at higher frequencies and then declined. All the above data and similar records from many other sites (ESM Table S3, available online) seem to illustrate a dry phase immediately prior to the Alnus decline, a short wet shift at the decline and then drier conditions again. Furthermore, a striking difference between the pollen data from lakes (Fig. 2) and peat bogs (Fig. 3) concerning the trajectory of the Pinus 
pollen curves might be an argument for the involvement of a dry period in the low Alnus pollen phase.

\section{Discussion}

\section{Geographic range and timing of the event}

The report by Stivrins et al. (2017) indicates that the Alnus decline was a widespread event in northeastern Europe, while the present data extend the range into north-central Europe (northern and central Poland). Furthermore, the event is well marked in some sites in Germany, Denmark, and southern Sweden (Fig. 1). A further, systematic examination of the pollen diagrams from Europe is needed to determine the area affected by the Alnus decline in more detail.

The review of the pollen profiles from Poland (ESM Table S3, available online) suggests that hydrological disturbances around this event with a clear dry period were involved. The temporary water deficit could have resulted in the formation of short-lived hiatuses or in a slowing down of the sediment accumulation rate in the peat bogs, which might be one of the potential reasons for the weak expression of the decline in some diagrams, while dating uncertainty makes it difficult to observe the event in some other records. The main challenge in reconstructing the exact timing and duration of palaeoecological events is the limited accuracy of the chronologies of the sediment sequences, which should be borne in mind, particularly when discussing the dating of short-lived events (cf. Bennett and Fuller, 2002), their synchronicity among sites (Parnell et al., 2008) and their correlation with other data (Blaaw, 2012). However, the chronological data provided in this paper, based not only on age/depth models but also on 30 radiocarbon dates performed on samples taken in 20 sites directly at the decline level or immediately next to it and a varve chronology in three lakes (Lake Czechowskie, Lake Szurpiły and Lake Żabińskie), allow us to suggest that the decline was roughly synchronous, starting approximately in the $9^{\text {th }}-10^{\text {th }}$ centuries, with a strong indication of the $10^{\text {th }}$ century. These new data from Poland permit a narrowing of the chronology of the major Alnus decline event in relation to the 
600-1000 CE timespan suggested in our earlier paper, which was based mainly on data from northeastern Europe (Stivrins et al., 2017). It is worth noting that in that area, the majority of the dates for the decline are between 900 and 1000 CE (Saarse et al., 2010; Stivrins et al., 2017). Similar results are shown in the pollen diagrams from Germany (Litt et al., 2009; Dörfler et al., 2012), Denmark (Aaby, 1988) and southern Sweden (Lagerås, 1996; de Jong and Lagerås, 2011; Fredh et al., 2013). After a detailed revision of the original pollen diagrams analysed in this study and considering the basis for their chronostratigraphy, it seems that the earlier dates might be, in most cases, an artefact caused by poor dating accuracy resulting from the inadequate number of radiocarbon dates used for the age/depth models or the sediment disturbances following dry shifts in the local hydrology. However, we should also accept that at least some of these earlier Alnus declines could have been separate events resulting from human impacts (e.g., Wojnowo site; Wacnik et al., 2012) or natural factors devastating local alder populations. This explanation seems to be reinforced by the results of the SiZer analysis provided in this study, indicating distinct shifts in alder pollen curves at approximately half of the first millennium CE preceding the major decline.

The results of this study, especially the data from the annually laminated sediments of three lakestake Czechowskie, demonstrated the very fast recovery rate of the early medieval alder population. According to the varve chronology, the alder population minimum was reached after approximately 50-100-years from the start of the decline, it stayed at this low level for approximately 50-70-140 years, and during the next approximately 30 years, the population reached the predisturbance level. This demonstrates the great resilience of alder forest ecosystems, even if they are exposed to severe natural disturbances. The early age when A. glutinosa starts its reproduction (12-20 years according to Tallantire, 1974) is certainly among the important factors here. Another point worth mentioning is that our calculation of the alder recovery rate is close to the average recovery time for forest ecosystems (42 years) given by Jones and Schmitz (2009).

\section{Potential causes of the Alnus decline}

The Alnus pollen decline shows individual features that are distinctly different from the pollen curve trajectories of other tree taxa, suggesting that the alder population dieback was triggered by a specific factor. Knowing the cause of the Alnus decline is critical for understanding the significance and implications of this event in long-term forest dynamics. As with Tsuga (Foster et al., 2006) and Ulmus (Parker et al., 2002) declines, abrupt climate changes, human influences, or disturbances such as 
pathogen outbreaks or fires should all be considered in the discussion of potential factors involved in this event.

In earlier papers, Sarmaja-Korjonen (2003) and Saarse et al. (2010) suggested human influence as the likeliest candidate for the Alnus declines in southern Finland and Estonia, respectively. In fact, most of the pollen sites studied by these authors lie in areas where the event was concurrent with settlement development. However, according to a more recent study, the decline also occurred at many boreal sites where evidence of contemporary human activity is absent, indicating that changes in agricultural practices cannot explain the sudden decrease of the Alnus population in this region (Stivrins et al., 2017).

Similar results were obtained in the present study. Although in a great portion of the sites, the Alnus decline overlapped with the beginning of settlement development (e.g., Noryśkiewicz, 2013; Pędziszewska et al., 2015; Pędziszewska and Latałowa, 2016), making it difficult to separate the results of human-induced deforestation and natural disturbances in alder stands, other pollen data from Poland and those from other regions indicate that the widespread alder population decline took place regardless of the state of local settlement development. A strong decline has been recorded in the profiles from Białowieża Forest (this paper) and Mechacz Wielki (Gałka et al., 2017), for example, in which anthropogenic indicators are almost absent, in those that reflect weak early medieval occupation (e.g., Lake Suminko - this paper), and in many sites where settlement was already developed, as in northcentral Poland (Noryśkiewicz, 2013), northwestern Poland (Latałowa, 1992; Noryśkiewicz, 2014; Bloom, 2015; Lamentowicz et al., 2015) and northeastern Germany (Dörfler et al., 2012). There are also sites where the Alnus decline was concurrent with the evidence of decreasing agricultural activity or even a short-lived disruption in settlement development (e.g., Kupryjanowicz and Fiłoc, 2016; Lake Czechowskie - this paper). Fires as a triggering factor may also be rejected. The available microcharcoal data do not show any consistent results in this respect. In some sites, high charcoal peaks occurred with the Alnus decline (Marcisz et al., 2015); in others, the charcoal frequency was low at the event level (Lake Suminko and Lake Czechowskie - this paper). Similar results have been provided by Stivrins et al. (2017).

An additional argument against the human impacts explanation is the fast recovery of the Alnus population even when the pollen values for the anthropogenic indicators were rising, which was clearly expressed in most of the pollen diagrams. Thus, arguing for human influence would require answering why humans not only suddenly began to use/destroy Alnus stands but also why they suddenly stopped 
435

436

437

438

10439

11

12440

13

14441

15442

16

17443

18

19444

20

doing so. Moreover, an explanation invoking human impacts does not provide a sound rationale for the event, especially for its alder-specific character, abruptness, and synchronous occurrence over the large geographic range.

Abrupt climate shifts would be another potential factor for the Alnus decline. The wet episode recorded in some peat bogs concurrently with the early phase of the decline and the subsequent dry period reflected in most sites analysed in this study might be of interest here.

The wet shift indicated in some sites presented in this study seems to conform with the dendrochronological and historical data from Europe, which show that the generally warm and dry period of the $9^{\text {th }}$ century and the first half of the $10^{\text {th }}$ century was punctuated by several short, cold shifts (Yavuz et al., 2007; Büntgen et al., 2016) and flooding events (Stothers, 1998). Historical sources indicate that Europe experienced several harsh winters every few years in the $9^{\text {th }}$ and the first half of the $10^{\text {th }}$ century when the Danube, Elbe, and Rhine rivers and even the Adriatic Sea were frozen (Yavuz et al., 2007). Some of the harsh winters directly followed the major volcanic eruptions of Katla in 822-823 CE (Büntgen et al., 2017), Eldgjá in 934 CE (Stothers, 1998) and Changbaishan (Tianchi Paektu) in 946 CE (Sun et al., 2014). Harsh, long winters usually result in floods and the transport of ice blocks, which may damage alder trees, making them more vulnerable to infection by pathogenic fungi (Ballesteros et al., 2010). Volcanic eruptions may also be followed by high precipitation events, which are another cause of flooding (Gao and Gao, 2017) affecting riparian forests. Historical sources reviewed by Stothers (1998) reported excessive flooding in France and Germany in the period following the Eldgjá eruption. In fact, our data from Gdańsk confirm the presence of floods prior to the Alnus decline (Święta-Musznicka et al., 2011; Święta-Musznicka and Latałowa, 2016), which is in agreement with other studies showing that in Poland, floods were particularly frequent around the $10^{\text {th }}$ century (Maclin et al., 2006; Gębica and Wojtal, 2011). Thus, one or a series of floods could have initiated the Alnus decline.

Certainly, the subsequent dry period was unfavourable for alder fitness as well. A. glutinosa is adapted to a wide range of temperatures, but its occurrence depends on the availability and abundance of water. Its leaves have no mechanism for controlling transpiration, and its roots, when exposed to air, are extremely vulnerable to cavitation (Hacke and Sauter, 1996; Claessens et al., 2010); thus, water deficits during dry and warm summers may affect the tree. Drought as the possible agent for the Alnus decline has already been suggested by Noryśkiewicz (2013) and Święta-Musznicka and Latałowa (2016). In fact, the occurrence of a dry period reflected in several sites analysed in this study agrees 
with the data from many regions of northern and central Europe. The prevalence of dry conditions in the $9^{\text {th }}-10^{\text {th }}$ centuries has been documented in such distant locations as Kontolanrahka Bog in southern 468 Finland (Väliranta et al., 2007), Männikjärve Bog in Estonia (Sillasoo et al., 2007), and Misten Bog in eastern Belgium (De Vleeschouwer et al., 2012; Streel et al., 2014). A drop in the effective humidity in the raised bogs in southwest Sweden (predominantly dry summers) in the $9^{\text {th }}\left(8^{\text {th }}\right)-10^{\text {th }}$ centuries has been reported by de Jong et al. $(2007,2009)$. These data seem to be concordant with the results of the dendroclimatological study by Helama et al. (2009), indicating distinct and persistent summer droughts from the early $9^{\text {th }}$ to the early $13^{\text {th }}$ centuries that were caused by a prolonged rainfall deficit in Finland. High-resolution hydroclimatic data from lowland Central Europe also indicate a dry spell for at least part of the $10^{\text {th }}$ century (Büntgen et al., 2011) and strong negative extremes (droughts) in this period (Dobrovolný et al., 2015). Low water levels in the mid-European lakes have been reconstructed by Magny (2004). Persistent droughts at the end of the first millennium CE and the beginning of the second millennium occurred in various regions of Europe and globally (Cook et al., 2015).

The coincidence between the Alnus decline and the period in which flash floods and summer droughts occurred seems to be a good argument for the event. However, it still does not explain the alder-specific character and suggests a possible impact of additional factors. Therefore, we hypothesize that a cumulative effect of climate change and the outbreak of pathogens provides an explanation that is most consistent with the characteristics of the Alnus decline.

The role of pathogens as a cause of the Alnus decline was also speculated by Sarmaja-Korjonen (2003), who considered it, however, a less likely reason for the event because of doubts about whether a pathogen would destroy Alnus on such a scale that it would appear in pollen diagrams and whether the damage caused by a pathogen would persist for hundreds of years. We now know that pathogen outbreaks can occur on continental spatial scales, covering hundreds of thousands of square kilometres and impacting trees and forests to an extent that can be clearly reflected in the pollen values of the host species (Bradshaw and Sykes, 2014) and the abundant presence of parasite spores (van Geel and Andersen, 1988). In addition, the decline would not be an event where one generation of trees is killed, but rather the pathogen would exert influence over tens or hundreds of years (Latałowa et al., 2013; Waller, 2013).

One possible cause of such a pathogen outbreak could be is-Phytophthora sp. Phytophthora is a genus comprising about 150 known taxa of fungi that are responsible for over $66 \%$ of fine root diseases and over $90 \%$ of collar rots of woody plants in different parts of the world. Currently, in Europe, about 
497

498

499

500

0501

11

12502

13

14503

15504

16

17505

18

19506

20

20 indigenous and alien Phytophthora taxa have been detected, most of them heavily devastating tree nurseries and forests. Since the early 1990s, a root and collar rot epidemic caused by interspecific hybrids of Phytophthora has led to high levels of mortality of alder in riparian forests in most parts of Europe (Jung et al., 2016). Although the present-day fungus is-most virulent to the-alder Phytophthora alni subsp. alni , is a recent hybrid (Brasier et al., 2004), we may suspect a similar process in the past, especially because several Phytophthora species are probably indigenous in European forests (Santini et al., 2013), and experimental studies have shown that a range of non-host-specific taxa of this genus may be a serious threat to A. glutinosa (Haque and Diez, 2012). Floods and droughts are generally recognized as the main risk factors for Phytophthora epidemics (Strnadová et al., 2010; Sturrock et al., 2011; Aguayo et al., 2014). As a relatively soft-xylem species, A. glutinosa has been found to be vulnerable if exposed to flash floods because high discharge and debris transport often result in wounded trees, increasing their exposure to pathogens (Ballesteros et al., 2010). Moreover, summer flooding and persistent stagnant water after the event may damage alder roots because of anoxia, as has been recorded along several European rivers in recent times (Bjelke et al., 2016). Phytophthora zoospores are transported by water, and floods are thus an important vector for their effective and rapid spread. The recently observed alder dieback spread over large areas of Europe roughly over a decade (Jung and Blaschke, 2004).

We thus propose that the Alnus decline at the end of the first millennium CE was an effect of factors similar to those involved in the present-day mass damage to alder forests. The decline may have been initiated by large-scale flood events that damaged the alder stands and disseminated Phytophthora spores over large areas. The subsequent dry period would reinforce the effect of a pathogen outbreak. According to Desprez-Loustau et al. (2006), field observations confirm the stimulating effect of alternating wet and dry periods on the disease.

As already discussed in our earlier paper (Stivrins et al., 2017), the difficulty of detecting whether the pathogen outbreak was the cause of the Alnus decline is the lack of direct fossil data that would reflect the occurrence of any pathogen in our records. The remains of some fungi are preserved in a fossil state and sustain the chemical treatment used for preparing pollen samples (van Geel and Aptroot, 2006), but in the case of Phytophthora, only molecular biology methods would be effective (Stivrins et al., 2017). Considering some indirect arguments, it is interesting to note the mass occurrence of the remains of Coniochaeta lignaria concurrent with the on-site Alnus decline in Gdańsk (Święta-Musznicka and Latałowa, 2016). Although this endophytic fungus has a wide spectrum of 
occurrence, it is also known from its concomitance with Phytophthora and from its antagonistic effects against this plant pathogen (Kokaew et al., 2011). 
about a similar, catastrophic decline occurring one thousand years ago is of special importance for the management of riverine forests following both nature conservation and economic issues. Considering the synchronicity of the Alnus decline over a large geographic region and that the location of the most important habitats for alder are in connection with rivers, which is similar to the present-day observation, the critical role of floods is strongly suggested as both a stress factor for alder trees and an agent for rapidly disseminating pathogen propagules. Our study also illustrates in a long-term perspective the great resilience of alder that enables natural, successful regeneration of its stands if environmental conditions improve.

Acknowledgments. The authors thank Achim Brauer and Mirosław Błaszkiewicz for permission to use the unpublished data from Lake Czechowskie, which contribute to the Virtual Institute of Integrated Climate and Landscape Evolution Analyses (ICLEA), grant number VH-VI-415, and-Karolina Bloom for access to the pollen data from Lake Racze/Miedwie, and Agnieszka Wacnik and Mirosława Kupryjanowicz for the detailed data on the Alnus decline in Lakes Żabińskie and Szurpiły. The unpublished data provided by AMN are a part of the project financed by the Polish Ministry of Science and Higher Education (11H 120526 81). ML, JŚM, AP, and MZ acknowledge support from the University of Gdańsk through statutory funding (530-L145-D581-18) and NS and HS the support of the Academy of Finland (EBOR project).

Authors' contribution. M.L., H.S., J.Ś-M., N.S, and M.S. conceived and discussed the ideas; M.L., J.ŚM., A.P., and A.M.N. collected and critically analyzed the data; M.Z., A.M.N., M.O., and F.O. shared their unpublished data; L.P., L.I., and L.H. did the statistical analysis; M.L. wrote the manuscript and all co-authors contributed in completing and correcting the manuscript and approved its final version.

\section{References}

Aaby B (1988) The Cultural Landscape as Reflected in Percentage and Influx Pollen Diagrams from Two Danish Ombrotrophic Mires. In: Birks HH, Birks HJB, Kaland D and Moe D (eds) The Cultural landscape, Past, Present and Future. Cambridge, UK: Cambridge University Press, pp. 209-228. 
Aguayo J, Elegbede F, Husson C et al. (2014) Modeling climate impact on an emerging disease, the Phytophthora alni-induced alder decline. Global Change Biology 20: 3209-3221.

590

591

592

593

11

12594

13

14595

15596

16

17597

18

19598

20

Allison TD, Moeller RE and Davis MB (1986) Pollen in Laminated Sediments Provides Evidence For a Mid-Holocene Forest Pathogen Outbreak. Ecology 67: 1101-1105.

Ammann B, van Leeuwen JFN, van der Knaap WO et al. (2013) Vegetation responses to rapid warming and to minor climatic fluctuations during the Late-Glacial Interstadial (GI-1) at Gerzensee (Switzerland). Palaeogeography, Palaeoclimatology, Palaeoecology 391: 40-59.

Ballesteros JA, Stoffel M, Bollschweiler M et al. (2010) Flash-flood impacts cause changes in wood anatomy of Alnus glutinosa, Fraxinus angustifolia and Quercus pyrenaica. Tree Physiology 30: 773-781.

Batchelor CR, Branch NP, Allison EA et al. (2014) The timing and causes of the Neolithic elm decline: New evidence from the Lower Thames Valley (London, UK). Environmental Archaeology 19: 263-290.

Bennett KD and Fuller JL (2002) Determining the age of the mid-Holocene Tsuga canadensis (hemlock) decline, eastern North America. The Holocene 12(4): 421-429.

Bjelke U, Boberg J, Oliva J et al. (2016) Dieback of riparian alder caused by the Phytophthora alni complex: projected consequences for stream ecosystems. Freshwater Biology 61: 565-579.

Blaauw M (2012) Out of tune: the dangers of aligning proxy archives. Quaternary Science Reviews 36: $38-49$.

Bloom K (2015) Wpływ czynników naturalnych i gospodarki pradziejowej na sukcesję roślinności w rejonie Jeziora Raczego na Ziemi Pyrzyckiej w holocenie. Studium paleoekologiczne. PhD Thesis, University of Gdańsk, Poland.

Boratyński A (1980) Systematyka i geograficzne rozmieszczenie olsz. In: Białobok S (ed) Olsze Alnus Mill. Nasze drzewa leśne. Warszawa-Poznań: PWN, pp.35-71.

Bradshaw RHW and Sykes MT (2014) Ecosystem Dynamics. From the past to the future. UK: WileyBlackwell.

Brasier CM, Kirk SA, Delcan J et al. (2004) Phytophthora alni sp. nov. and its variants: designation of emerging heteroploid hybrid pathogens spreading on Alnus trees. Mycological Research 108: 1172-1184.

Bronk Ramsey C and Lee S (2013) Recent and Planned Developments of the Program OxCal. Radiocarbon 55: 720-730. 
620 621

622 623

0624 11 12625 13 14626 15627 16 17628 18 19629

Büntgen U, Eggertsson Ó, Wacker L et al. (2017) Multi-proxy dating of Iceland's major pre-settlement Katla eruption to 822-823 CE. Geology 45: 783-786.

Büntgen U, Myglan VS, Ljungqvist FC et al. (2016) Cooling and societal change during the Late Antique Little Ice Age from 536 to around 660 AD. Nature Geoscience 9: 231-236.

Büntgen U, Tegel W, Nicolussi K et al. (2011) 2500 years of European climate variability and human susceptibility. Science 331: 578-582.

Chaudhuri P and Marron JS (2000) Scale space view of curve estimation. Annals of Statistics 28(2): 408-428.

Claessens H, Oosterbaan A, Savill P and Rondeux J (2010) A review of the characteristics of black alder (Alnus glutinosa (L.) Gaertn.) and their implications for silvicultural practices. Forestry 83: $163-175$.

Clark SHE and Edwards KJ (2004) Elm bark beetle in Holocene peat deposits and the northwest European elm decline. Journal of Quaternary Science 19: 525-528.

Clements WH and Rohr JR (2009) Community responses to contaminants: using basic ecological principles to predict ecotoxicological effects. Environmental toxicology and chemistry 28: 17891800.

Clements WH, Vieira NKM and Sonderegger DL (2010) Use of ecological thresholds to assess recovery in lotic ecosystems. Journal of the North American Benthological Society 29: 10171023.

Cole LE, Bhagwat SA and Willis KJ (2014) Recovery and resilience of tropical forests after disturbance. Nature Communications 5: 3906.

Cook ER, Seager R, Kushnir Y et al. (2015) Old World megadroughts and pluvials during the Common Era. Science Advances 1: e1500561.

Czymzik M, Muscheler R, Adolphi F et al. (2018) Synchronizing ${ }^{10} \mathrm{Be}$ in two varved lake sediment records to IntCal13 ${ }^{14} \mathrm{C}$ during three grand solar minima. Climate of the Past 14: 687-696.

Davis MB (1981) Outbreaks of forest pathogens in Quaternary history. In: Bharadwaj D, Vishnu-Mittre $\mathrm{X}$ and Maheshwari H (eds) Proceedings of the Fourth International Palynological Conference. Lucknow, India: Birbal Sahni Institute of Paleobotany, pp.216-227.

de Jong R, Hammarlund D and Nesje A (2009) Late Holocene effective precipitation variations in the maritime regions of south-west Scandinavia. Quaternary Science Reviews 28: 54-64. 
de Jong R and Lagerås P (2011) Exploring the patterns and causes of land use changes in south-west Sweden. Vegetation History and Archaeobotany 20: 15-27.

652 de Jong R, Schoning K and Bjorck S (2007) Increased aeolian activity during humidity shifts as 653 recorded in a raised bog in south-west Sweden during the past 1700 years. Climate of the Past 3 : 411-422.

De Vleeschouwer F, Pazdur A, Luthers C et al. (2012) A millennial record of environmental change in peat deposits from the Misten bog (East Belgium). Quaternary International 268: 44-57.

Desprez-Loustau ML, Marçais B, Nageleisen LM et al. (2006) Interactive effects of drought and pathogens in forest trees. Annals of Forest Science 63: 597-612.

Dewald LE and Steiner KC (1986) Phenology, height increment, and cold tolerance of Alnus glutinosa populations in a common environment. Silvae Genetica 35: 205-211.

Dobrovolný P, Rybníček M, Koláŕ T et al. (2015) A tree-ring perspective on temporal changes in the frequency and intensity of hydroclimatic extremes in the territory of the Czech Republic since 761 AD. Climate of the Past 11: 1453-1466.

Dörfler W, Feeser I, van den Bogaard C, Dreibrodt S et al. (2012) A high-quality annually laminated sequence from Lake Belau, Northern Germany: Revised chronology and its implications for palynological and tephrochronological studies. The Holocene 22: 1413-1426.

EPD. The European Pollen Database (www.europeanpollendatabase.net).Flynn LE and Mitchell FJG (2018) Comparison of a recent elm decline with the mid-Holocene Elm Decline. Vegetation History and Archaeobotany. doi.org/10.1007/s0033 4-018-0698-3) Foster DR, Oswald WW, Faison EK et al. (2006) A Climatic Driver for Abrupt Mid-Holocene Vegetation Dynamics and the Hemlock Decline in New England. Ecology 87: 2959-2966.

Fredh D, Broström A, Rundgren M et al. (2013) The impact of land-use change on floristic diversity at regional scale in southern Sweden 600 BC-AD 2008. Biogeosciences 10: 3159-3173.

Gałka M, Tobolski K, Lamentowicz $Ł$ et al. (2017) Unveiling exceptional Baltic bog ecohydrology, autogenic succession and climate change during the last 2000 years in CE Europe using replicate cores, multi-proxy data and functional traits of testate amoebae. Quaternary Science Reviews 156: 90-106.

Gao Y and Gao C (2017) European hydroclimate response to volcanic eruptions over the past nine centuries. International Journal of Climatology 37: 4146-4157. 
680

681

682

683

684

11

12685

13

14

15687

16

17688

18

19689

20

Gębica P and Wojtal G (2011) Neoholocene river accumulation and flood phase in small valleys mar the Carpathian margin. Annales Universitatis Mariae Curie-Skłodowska, Lublin-Polonia, sect. B, 66: 63-75.

Ghilardi B and O'Connell M (2013) Early Holocene vegetation and climate dynamics with particular reference to the $8.2 \mathrm{ka}$ event: pollen and macrofossil evidence from a small lake in western Ireland. Vegetation History and Archaeobotany 22: 99-114.

Gilewska S (1991) Rzeźba. In: Starkel L (ed) Geografia Polski. Środowisko przyrodnicze. Wydaw. Nauk. PWN, Warszawa, pp.248-296.

Girling MA and Greig J (1985) A first fossil record for Scolytus scolytus (F.) (elm bark beetle): its occurrence in elm decline deposits from London and the implications for neolithic elm disease. Journal of Archaeological Science 12: 347-351.

Hacke U and Sauter JJ (1996) Drought-Induced Xylem Dysfunction in Petioles, Branches, and Roots of Populus balsamifera L. and Alnus glutinosa (L.) Gaertn. Plant Physiology 111: 413-417.

Haque MM and Diez JJ (2012) Susceptibility of common alder (Alnus glutinosa) seeds and seedlings to Phytophthora alni and other Phytophthora species. Forest Systems 21: 313-322.

Helama S, Merilainen J and Tuomenvirta H (2009) Multicentennial megadrought in northern Europe coincided with a global El Nino-Southern Oscillation drought pattern during the Medieval Climate Anomaly. Geology 37: 175-178.

Iversen J (1941) Land occupation in Denmark's stone age: a pollen-analytical study of the influence of farmer culture on the vegetational development. Danmarks Geologiske Undersølgelse II, 66: 523.

Jahns S (2000) Late-glacial and Holocene woodland dynamics and land-use history of the Lower Oder valley, north-eastern Germany, based on two, AMS ${ }^{14} \mathrm{C}$-dated, pollen profiles. Vegetation History and Archaeobotany 9: 111-123.

Jalas J and Suominen J (1976) Atlas Florae Europaeae. Distribution of vascular plants in Europe. 3. Salicaceae to Balanophoraceae. Helsinki: The Committee for Mapping the Flora of Europe and Societas Biologica Fennica Vanamo.

Jeger MJ and Pautasso M (2008) Plant disease and global change-the importance of long-term data sets. New Phytologist 177: 8-11.

Jones HP and Schmitz OJ (2009) Rapid Recovery of Damaged Ecosystems. PLoS ONE 4(5): e5653. https://doi.org/10.1371/journal.pone.0005653 
Jung T and Blaschke M (2004) Phytophthora root and collar rot of alders in Bavaria: distribution, modes of spread and possible management strategies. Plant Pathology 53: 197-208.

Jung T, Orlikowski L, Henricot B et al. (2016) Widespread Phytophthora infestations in European nurseries put forest, semi-natural and horticultural ecosystems at high risk of Phytophthora diseases. Forest Pathology 46: 134-163.

Kajba D and Gracan J (2003) EUFORGEN Technical Guidelines for genetic conservation and use for Black Alder (Alnus glutinosa). Rome, Italy: International Plant Genetic Resources Institute. Available at: www.euforgen.org/publications/technical-guidelines (accessed 20 November 2018).

Kaniewski D, Marriner N, Morhange C et al. (2016) Solar pacing of storm surges, coastal flooding and agricultural losses in the Central Mediterranean. Scientific Reports 6: 25197.

Kinder M, Tylmann W, Enters D et al. (2013) Construction and validation of calendar-year time scale for annually laminated sediments - an example from Lake Szurpiły (NE Poland). GFF 135: 248257.

Kitagawa J, Morita Y, Makohonienko M et al. (2016) Understanding the human impact on Akita-sugi cedar (Cryptomeria japonica) forest in the late Holocene through pollen analysis of annually laminated sediments from Ichi-no-Megata, Akita, Japan. Vegetation History and Archaeobotany 25: 525-540.

Kokaew J, Manoch L, Worapong J et al. (2011) Coniochaeta ligniaria an endophytic fungus from Baeckea frutescens and its antagonistic effects against plant pathogenic fungi. Thai Journal of Agricultural Science 44: 123-131.

Kramer K, Vreugdenhil SJ and van der Werf DC (2008) Effects of flooding on the recruitment, damage and mortality of riparian tree species: A field and simulation study on the Rhine floodplain. Forest Ecology and Management 255: 3893-3903.

Kupryjanowicz M and Fiłoc M (2016) Palynological studies in the Yatwing territory. In: BitnerWróblewska A, Brzeziński W and Kasprzycka M (eds) Yatwing Archaeology - Past Research, New Perspectives. Warszawa, Poland: Państwowe Muzeum Archeologiczne, pp.133-157.

La Porta N, Capretti P, Thomsen IM et al. (2008) Forest pathogens with higher damage potential due to climate change in Europe. Canadian Journal of Plant Pathology 30: 177-195.

Lagerås P (1996) Vegetation and land-use in the Småland Uplands, southern Sweden, during the last 6000 years. PhD Thesis, Lund University, Sweden. 
741

742

743

744

0745

11

12746

13

14747

15748

16

17749

18

19750

20

23

24753

25

$26^{754}$

27755

29756

30

31757

Lamentowicz M, Gałka M, Lamentowicz $\ell$ et al. (2015) Reconstructing climate change and ombrotrophic bog development during the last 4000 years in northern Poland using biotic proxies, stable isotopes and trait-based approach. Palaeogeography, Palaeoclimatology, Palaeoecology 418: 261-277.

Latałowa M (1992) Man and vegetation in the pollen diagrams from Wolin Island (NW Poland). Acta Palaeobotanica 32: 123-249.

Latałowa M, Pędziszewska A, Maciejewska E and Święta-Musznicka J (2013) Tilia forest dynamics, Kretzschmaria deusta attack, and mire hydrology as palaeoecological proxies for mid-Holocene climate reconstruction in the Kashubian Lake District (N Poland). The Holocene 23: 667-677.

Latałowa M, Zimny M, Pędziszewska A and Kupryjanowicz M (2016) Postglacjalna historia Puszczy Białowieskiej - roślinność, klimat i działalność człowieka. Parki Narodowe i Rezerwaty Przyrody 35: 3-49.

Litt T, Scholzel C, Kuhl N and Brauer A (2009) Vegetation and climate history in the Westeifel Volcanic Field (Germany) during the past 11000 years based on annually laminated lacustrine maar sediments. Boreas 38: 679-690.

Lorenc H (ed) (2005) Atlas klimatu Polski. Warszawa, Poland: Instytut Meteorologii i Gospodarki Wodnej. Available at: www.imgw.pl/wl/internet/zz/klimat/0502polska.html (accessed 20 November 2018).

Macklin MG, Benito G, Gregory KJ et al. (2006) Past hydrological events reflected in the Holocene fluvial record of Europe. Catena 66: 145-154.

Magny M (2004) Holocene climate variability as reflected by mid-European lake-level fluctuations and its probable impact on prehistoric human settlements. Quaternary International 113: 65-79.

Mann ME, Rahmstorf S, Kornhuber K et al. (2017) Influence of Anthropogenic Climate Change on Planetary Wave Resonance and Extreme Weather Events. Scientific Reports 7: 45242.

Marcisz K, Tinner W, Colombaroli D et al. (2015) Long-term hydrological dynamics and fire history over the last 2000 years in CE Europe reconstructed from a high-resolution peat archive. Quaternary Science Reviews 112: 138-152.

Morris JL, Courtney Mustaphi CJ, Carter VA et al. (2015) Do bark beetle remains in lake sediments correspond to severe outbreaks? A review of published and ongoing research. Quaternary International 387: 72-86. 
Noryśkiewicz AM (2013) Historia roślinności i osadnictwa ziemi chetmińskiej w późnym holocenie.

Studium palinologiczne. Toruń, Poland: Wydawnictwo Naukowe Uniwersytetu Mikołaja Kopernika.

Noryśkiewicz AM (2014) Vegetation and settlement history as reflected by pollen analysis. In: Chudziak W and Kaźmierczak R (eds) The Island in Żólte on Lake Zarańskie. Early Medieval Gateway into West Pomerania. Toruń, Poland: Institute of Archaeology, Nicolaus Copernicus University, pp._367-560.

Ott F, Wulf S, Serb J et al. (2016) Constraining the time span between the Early Holocene Hässeldalen and Askija-S Tephras through varve counting in the Lake Czechowskie sediment record, Poland. Journal of Quaternary Science 31(2): 103-113.

Pancer-Kotejowa E and Zarzycki K (1980) Zarys ekologii. In: Białobok S (ed) Olsze Alnus Mill. Nasze drzewa leśne. Warszawa-Poznań, Poland: PWN, pp. 229-257.

Parker AG, Goudie AS, Anderson DE et al. (2002) A review of the mid-Holocene elm decline in the British Isles. Progress in Physical Geography 26: 1-45.

Parnell AC, Haslett J, Allen JRM et al. (2008) A flexible approach to assesing synchroneity of past events using Bayesian reconstructions of sedimentation history. Quaternary Science Reviews 27: $1872-1885$.

Peglar SM (1993) The mid-Holocene Ulmus decline at Diss Mere, Norfolk, UK: a year-by-year pollen stratigraphy from annual laminations. The Holocene 3: 1-13.

Pędziszewska A (2008) Późnoholoceńska historia wybranych fitocenoz leśnych z udziałem grabu (Carpinus betulus L.) i buka (Fagus sylvatica L.) na Pojezierzu Kaszubskim. PhD Thesis, University of Gdańsk, Poland.

Pędziszewska A and Latałowa M (2016) Stand-scale reconstruction of late Holocene forest succession on the Gdańsk Upland (N. Poland) based on integrated palynological and macrofossil data from paired sites. Vegetation History and Archaeobotany 25: 239-254.

Pędziszewska A, Tylmann W, Witak M et al. (2015) Holocene environmental changes reflected by pollen, diatoms, and geochemistry of annually laminated sediments of Lake Suminko in the Kashubian Lake District (N Poland). Review of Palaeobotany and Palynology 216: 55-75.

Prentice IC (1985) Pollen representation, source area, and basin size: toward a unified theory of pollen analysis. Quaternary Research 23: 76-86. 
801

802

803

804

805

11

12806

13

14807

15808

16

17809

18

19810

20

R Development Core Team (2014) R: A language and environment for statistical computing. R Foundation for Statistical Computing, Vienna, Austria. Available at: www.R-project.org (accessed 20 November 2018).

Reimer PJ, Bard E, Bayliss A et al. (2013) Intcal13 and Marine13 Radiocarbon Age Calibration Curves 0-50,000 Years Cal BP. Radiocarbon 55(4): 1869-1887.

Saarse L, Niinemets E, Poska A and Veski S (2010) Is there a relationship between crop farming and the Alnus decline in the eastern Baltic region? Vegetation History and Archaeobotany 19: 17-28.

Santini A, Ghelardini L, De Pace C et al. (2013) Biogeographical patterns and determinants of invasion by forest pathogens in Europe. New Phytologist 197: 238-250.

Sarmaja-Korjonen K (2003) Contemporaneous Alnus decline and the beginning of Iron Age cultivation in pollen stratigraphies from southern Finland. Vegetation History and Archaeobotany 12: 49-59.

Seidl R and Rammer W (2017) Climate change amplifies the interactions between wind and bark beetle disturbances in forest landscapes. Landscape Ecology 32: 1485-1498.

Sillasoo Ü, Mauquoy D, Blundell A et al. (2007) Peat multi-proxy data from Männikjärve bog as indicators of late Holocene climate changes in Estonia. Boreas 36: 20-37.

Sonderegger D (2012) SiZer: SiZer: Significant Zero Crossings. R package version 0.1-4. http://CRAN.R-project.org/package=SiZer

Sonderegger DL, Wang H, Clements WH and Noon BR (2009) Using SiZer to detect thresholds in ecological data. Frontiers in Ecology and the Environment 7: 190-195.

Stivrins N, Buchan MS, Disbrey HR et al. (2017) Widespread, episodic decline of alder (Alnus) during the medieval period in the boreal forest of Europe. Journal of Quaternary Science 32: 903-907.

Stothers RB (1998) Far Reach of the Tenth Century Eldgjá Eruption, Iceland. Climatic Change 39: $715-726$.

Streel M, Beghin J, Gerrienne P et al. (2014) Late Subatlantic history of the ombrotrophic Misten Bog (Eastern Belgium) based on high resolution pollen, testate amoebae and macrofossil analysis. Geologica Belgica 17: 148-160.

Strnadová V, Černý K, Holub V and Gregorová B (2010) The effects of flooding and Phytophtora alni infection on black alder. Journal of Forest Science 56: 41-46.

Sturrock RN, Frankel SJ, Brown AV et al. (2011) Climate change and forest diseases. Plant Pathology 60: 133-149. 
Sugita S (1993) A model of pollen source area for an entire lake surface. Quaternary Research 39:

833 Sun C, Plunkett G, Liu J et al. (2014) Ash from Changbaishan Millennium eruption recorded in Greenland ice: Implications for determining the eruption's timing and impact. Geophysical Research Letters 41: 694-701. 
Wacnik A, Goslar T and Czernik J (2012) Vegetation changes caused by agricultural societies in the Great Mazurian Lake District. Acta Palaeobotanica 52: 59-104.

Wacnik A, Tylmann W, Bonk A et al. (2016) Determining the responses of vegetation to natural processes and human impacts in north-eastern Poland during the last millennium: combined pollen, geochemical and historical data. Vegetation History and Archaeobotany 25: 479-498.

\section{Figure legends}

Fig. 1 (ㅁa) Location of the study area and the Alnus decline sites outside Poland; ( $\underline{B} b)$ the area of Poland covered by the present paper; and $(\underline{\mathrm{C}})$ the area covered by earlier papers on the Alnus decline 
(Sarmaja-Korjonen, 2003; Saarse et al., 2010; Stivrins et al., 2017). On map 'b', green dots were used fora- pollen sites where the Alnus decline was well expressed, $\underline{b-}$ and yellow dots were used ifpollen sites where the event was lacking or weakly expressed; site numbers follow the list of sites (Table S1): Bråtamossen (Lagerås, 1996), Fiolen Lake (Fredh et al., 2013), Store Mosse Bog (de Jong and Lagerås, 2011), Holmegaard Bog (Aaby, 1988), Belau Lake (Dörfler et al., 2012), Felchowsee and Grosser Krebssee (Jahns, 2000), Holzmaar Lake and Meerfelder Maar Lake (Litt et al., 2009)

Fig. 2 Simplified pollen diagrams from selected lakes illustrating the Alnus decline against changes in other tree taxa, indicators of settlement activity and selected indicators of lake environment: Lake Czechowskie (Obremska and Ott, unpubl.), Lake Suminko (Pędziszewska et al., 2015), Lake Mełno (Noryśkiewicz, 2013), and Lake Zarańskie (Noryśkiewicz, 2014); dating of Lake Mełno and Lake Zarańskie sediments acc. to indirect premises (see Methods); site numbers as in Fig. 1 and ESM Table S1 (available online)

Fig. 3 Simplified pollen diagrams from the selected peat bogs illustrating the Alnus decline against changes in the other tree taxa, indicators of settlement activity and selected indicators of local hydrology: BIA/314D and BIA/318C (Zimny, 2014), Czerlon (Latałowa et al., 2016), Bagno Kusowo (Lamentowicz et al., 2015), and Słowińskie Błota/85 (Latałowa, unpubl.); site numbers as in Fig. 1 and ESM Table S1 (available online)

Fig. 4 Alnus pollen percentage values for the period AD 300-1400 in selected sites in Poland: BIA/340G, BIA/131C, BIA/314D and BIA/318C (Zimny, 2014), Czerlon (Latałowa et al., 2016), Lake Czechowskie (Obremska and Ott, unpubl.), Bukrzyno (Pędziszewska, 2008), (Lake Suminko (Pędziszewska et al., 2015), Bagno Kusowo (Lamentowicz et al., 2015), and Słowińskie Błota/85 (Latałowa, unpubl.); Lake Racze/Miedwie (Bloom, 2015); site numbers as in Fig. 1 and ESM Table S1 (available online)

Fig. 5 Analysis of the statistical significance of the decline-rise events in the Alnus populations in 11 selected sites in Poland (see the caption of Fig. 4 for site information) using the SiZer analysis (see ESM Figure S1, available online). a- A statistically significant declines, $b$ - is shown with red and a statistically significant rises is strongest decline at the end of the first 
922 millennium is shown with a dashed line. Because the data for three records was too sparse (BIA/131C, $923 \mathrm{BIA} / 314 \mathrm{D}$ and Bukrzyno/BI), no statistically significant decline-rise events were detected

\section{Supporting information}

1926 ESM Table S1 Alnus decline - pollen sites; Site category: A - primary sites, B - secondary sites;

Decline: a- present, b- no recovery, c- weak or not recorded; Age of the event: start of the decline, minimum value, recovery to the earlier level; EPD - European Pollen Database

ESM Table S2 Environmental metadata for the sites; site type concerns a period of the Alnus decline event; o- outflow, i- inflow; site numbers as in ESM Table S1 (available online) and Fig. 1

ESM Table S3 Palaeoecological characteristics around the Alnus decline; HI - human impact: h high, $\mathrm{m}$ - moderate, 1 - low, a - absent; NPPs - non-pollen palynomorphs; site numbers as in ESM Table S1(available online) and Fig. 1; for references, see Table S1

ESM Figure S1 The results of the SiZer analyses of Alnus pollen curves in selected sites in Poland (for site information, see the caption of Fig. 4 in the main text). In the maps, the horizontal axis represents the time, the vertical axis represents the scale and the colour of each pixel represents the significance of the derivative of the smooth of the curve at the corresponding time and scale. Red, blue and purple indicate that the derivative is significantly negative, positive or neither, respectively. Grey means that the data are too sparse for inference. The most suitable scales for the detection of the significant decline-rise events in the data are shown with vertical lines. The scale that reveals the decline-rise event at the end of the first millennium is shown with a yellow line, and the scales for the other events are shown with green lines 
Table 1 Radiocarbon dates and results of their calibration for the Alnus decline in Polish sites, with site numbers as in Fig. 1 and Table S1; for references see Table S1

\begin{tabular}{|c|c|c|c|c|c|c|}
\hline $\begin{array}{l}\text { Site } \\
\text { No. }\end{array}$ & Site name & Lab. No. & $\underset{\substack{\text { Age } \\
{ }^{14} \mathrm{C} \text { BP }}}{.}$ & $\begin{array}{c}\text { Median } \\
\text { AD }\end{array}$ & $\begin{array}{c}\text { Calibration } \\
\text { (26) AD }\end{array}$ & $\begin{array}{c}\text { Position of the date } \\
\text { in relation to the } \\
\text { event }\end{array}$ \\
\hline \multirow[t]{2}{*}{1} & \multirow[t]{2}{*}{ Lake Racze/Wolin } & Poz-74501 & $1135 \pm 30$ & 919 & $777-986$ & Decline \\
\hline & & Poz-74500 & $805 \pm 30$ & 1235 & $1170-1273$ & Full recovery \\
\hline \multirow[t]{2}{*}{3} & \multirow[t]{2}{*}{ Wolin II/00 } & Poz-29758 & $1015 \pm 30$ & 1014 & $971-1149$ & Decline \\
\hline & & Poz-29760 & $900 \pm 30$ & 1123 & $1039-1210$ & Recovery \\
\hline \multirow[t]{2}{*}{4} & \multirow[t]{2}{*}{ Lake Racze Miedwie } & Poz-49125 & $955 \pm 30$ & 1096 & $1022-1155$ & Minimum/early \\
\hline & & Poz-49124 & $935 \pm 30$ & 1105 & $1030-1175$ & Full recovery \\
\hline 7 & Bagno Kusowo & Poz-55359 & $1055 \pm 35$ & 988 & $895-1028$ & Decline/minimum \\
\hline 9 & Słowińskie Błota & Gd-1879 & $1000 \pm 40$ & 1032 & $975-1155$ & Start of the recovery \\
\hline 10 & Kluki & Gd-565 & $865 \pm 60$ & 1166 & $1038-1261$ & Recovery \\
\hline 11 & Darżlubie Forest & Gd-1032 & $1125 \pm 55$ & 911 & 774-1014 & Decline \\
\hline \multirow[t]{2}{*}{12} & \multirow[t]{2}{*}{ Gołębiewo (G/I) } & Poz-3624 & $1030 \pm 30$ & 1005 & $901-1116$ & Decline \\
\hline & & Poz-49034 & $895 \pm 35$ & 1130 & $1039-1215$ & Full recovery \\
\hline \multirow[t]{2}{*}{13} & \multirow[t]{2}{*}{ Gdańsk-Pszenna } & Poz-45048 & $1155 \pm 30$ & 881 & $775-969$ & Decline \\
\hline & & Poz-31661 & $840 \pm 35$ & 1202 & $1152-1267$ & Full recovery \\
\hline \multirow[t]{2}{*}{14} & \multirow[t]{2}{*}{ Gdańsk-Żytnia } & Poz-31658 & $1215 \pm 30$ & 812 & $694-889$ & Before the decline \\
\hline & & Poz-31657 & $1110 \pm 30$ & 937 & 879-1013 & Minimum \\
\hline \multirow[t]{3}{*}{$16 \mathrm{a}$} & \multirow[t]{3}{*}{ Stążki/2008 } & Poz-15781 & $1100 \pm 30$ & 946 & $887-1013$ & Minimum \\
\hline & & Poz-15782 & $1090 \pm 30$ & 954 & $892-1014$ & Minimum \\
\hline & & Poz-15780 & $1025 \pm 30$ & 1005 & $945-1110$ & Recovery \\
\hline 17 & Bukrzyno (B/I) & Poz-19361 & $1030 \pm 30$ & 1005 & $901-1116$ & Minimum \\
\hline 18 & Lake Suminko & GdA-2517 & $930 \pm 30$ & 1099 & $1025-1165$ & Recovery \\
\hline \multirow[t]{4}{*}{19} & \multirow[t]{4}{*}{ Lake Czechowskie } & \multirow{4}{*}{ Varves } & & 970 & \multirow{4}{*}{$\begin{array}{c} \pm 10 \text { varve } \\
\text { years }\end{array}$} & Decline \\
\hline & & & & 1020 & & Minimum \\
\hline & & & & 1090 & & Early recovery \\
\hline & & & & 1120 & & Full recovery \\
\hline \multirow[t]{2}{*}{$31 \mathrm{a}$} & \multirow[t]{2}{*}{ Linje } & Poz-56402 & $1145 \pm 35$ & 896 & $776-978$ & Decline/minimum \\
\hline & & Poz-54918 & $995 \pm 35$ & 1035 & $995-1145$ & Full recovery \\
\hline \multirow[t]{4}{*}{42} & \multirow[t]{4}{*}{ Lake Żabińskie } & & & 870 & & Decline \\
\hline & & Varves & & 920 & $+12 /-24$ & Minimum \\
\hline & & valves & & 1060 & varve years & Early recovery \\
\hline & & & & 1090 & & Full recovery \\
\hline 43 & Mechacz Wielki & Poz-46146 & $1095 \pm 30$ & 950 & 890-1013 & Early recovery \\
\hline \multirow[t]{4}{*}{44} & \multirow[t]{4}{*}{ Lake Szurpiły } & & & 830 & & Decline \\
\hline & & Varves & & 930 & \pm 42 years & Minimum \\
\hline & & valves & & 980 & 142 yeals & Early recovery \\
\hline & & & & 1010 & & Full recovery \\
\hline 48 & $\mathrm{BIA} / 318 \mathrm{C}$ & Poz-39678 & $1080 \pm 30$ & 966 & 894-1018 & Decline/minimum \\
\hline 49 & $\mathrm{BIA} / 314 \mathrm{D}$ & Poz-52241 & $1115 \pm 30$ & 933 & $779-1013$ & Decline/minimum \\
\hline & & Poz-58946 & $850 \pm 25$ & 1195 & $1154-1258$ & Recovery \\
\hline 52 & $\mathrm{BIA} / 131 \mathrm{C}$ & Poz-39672 & $1220 \pm 40$ & 803 & $684-892$ & Below the decline \\
\hline & & Poz-35662 & $685 \pm 30$ & 1296 & $1267-1389$ & Full recovery \\
\hline 54 & Czerlon & Poz-78644 & $1080 \pm 30$ & 966 & $894-1018$ & Decline/minimum \\
\hline
\end{tabular}




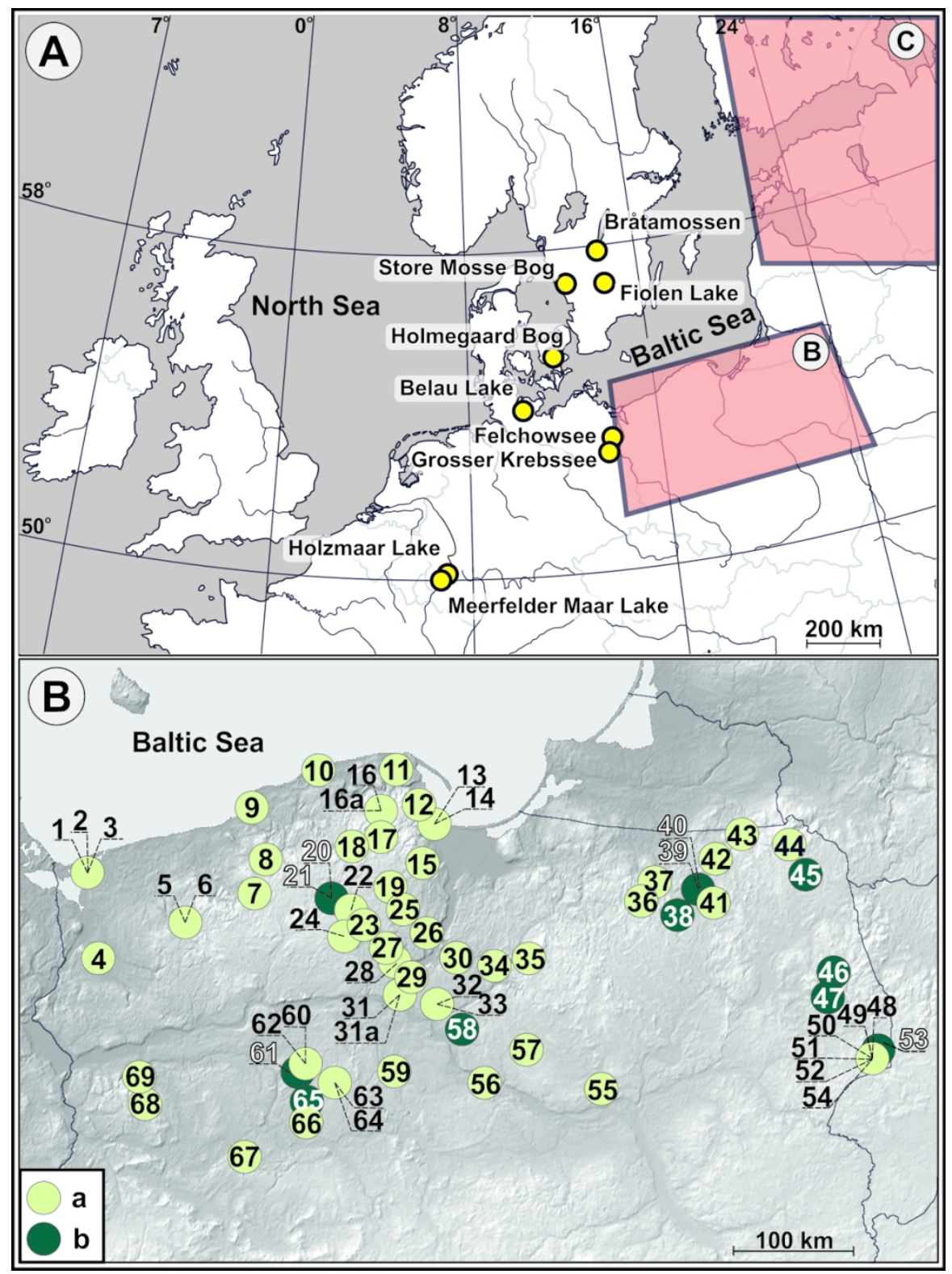

Fig. 1 (A) Location of the study area and the Alnus decline sites outside Poland; (B) the area of Poland covered by the present paper; and $(C)$ the area covered by earlier papers on the Alnus decline (SarmajaKorjonen, 2003; Saarse et al., 2010; Stivrins et al., 2017). a- pollen sites where the Alnus decline was well expressed, b- pollen sites where the event was lacking or weakly expressed; site numbers follow the list of sites (Table S1): Brătamossen (Lagerås, 1996), Fiolen Lake (Fredh et al., 2013), Store Mosse Bog (de Jong and Lagerås, 2011), Holmegaard Bog (Aaby, 1988), Belau Lake (Dörfler et al., 2012), Felchowsee and Grosser Krebssee (Jahns, 2000), Holzmaar Lake and Meerfelder Maar Lake (Litt et al., 2009) 

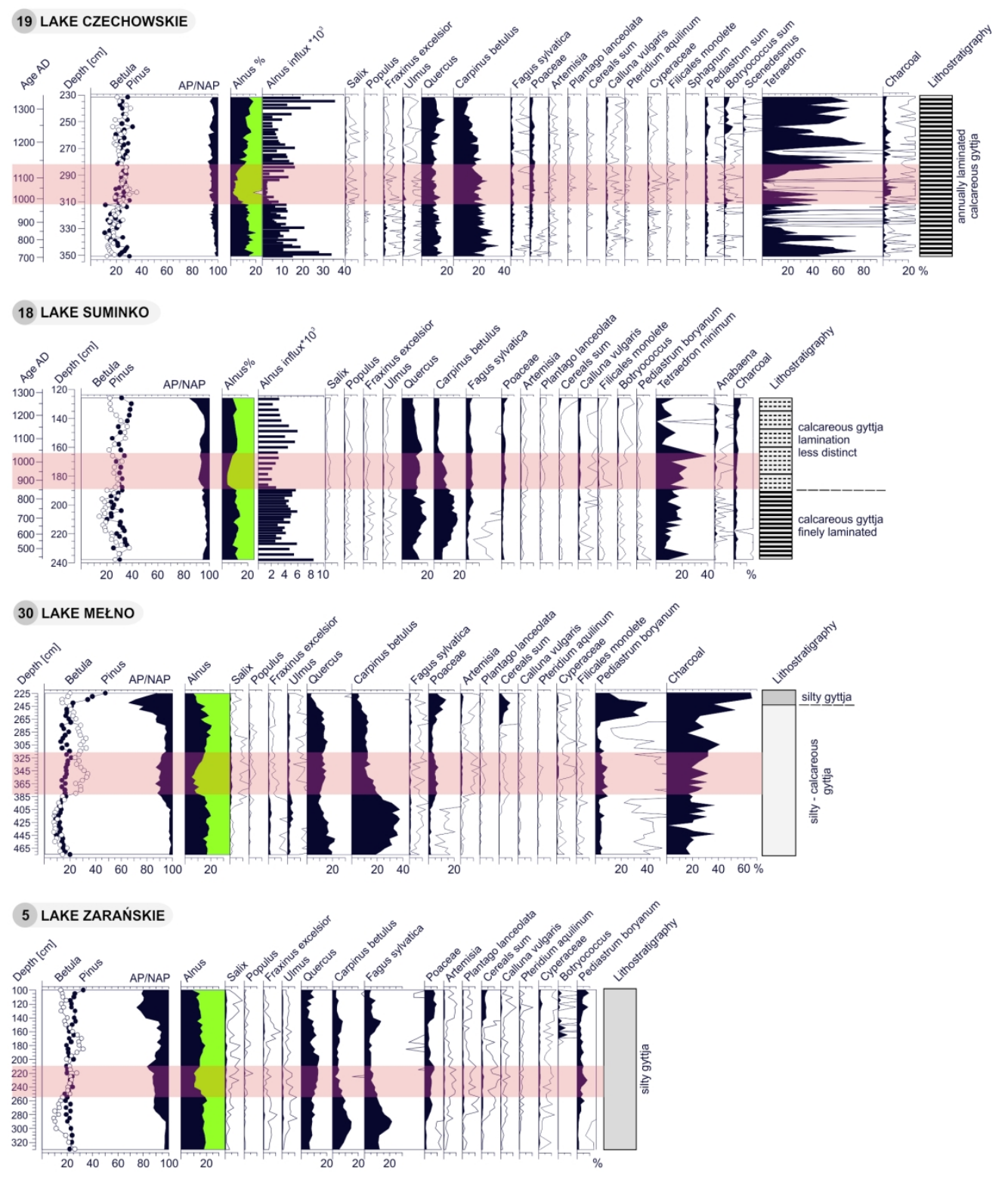

Fig. 2 Simplified pollen diagrams from selected lakes illustrating the Alnus decline against changes in other tree taxa, indicators of settlement activity and selected indicators of lake environment: Lake Czechowskie (Obremska and Ott, unpubl.), Lake Suminko (Pędziszewska et al., 2015), Lake Mełno (Noryśkiewicz, 2013), and Lake Zarańskie (Noryśkiewicz, 2014); dating of Lake Mełno and Lake Zarańskie sediments acc. to indirect premises (see Methods); site numbers as in Fig. 1 and ESM Table S1 (available online) 

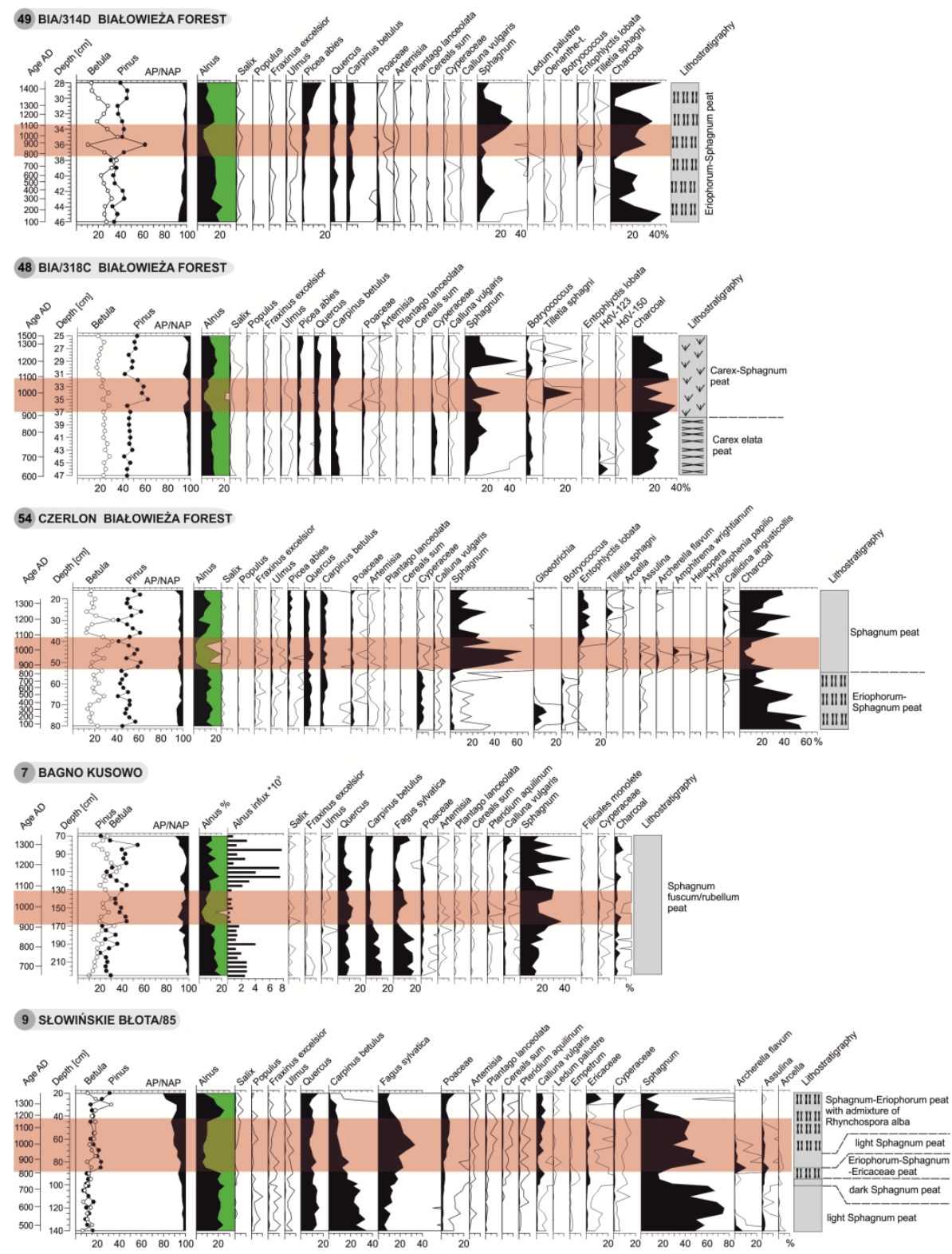

Fig. 3 Simplified pollen diagrams from the selected peat bogs illustrating the Alnus decline against changes in the other tree taxa, indicators of settlement activity and selected indicators of local hydrology: BIA/314D and BIA/318C (Zimny, 2014), Czerlon (Latałowa et al., 2016), Bagno Kusowo (Lamentowicz et al., 2015), and Słowińskie Błota/85 (Latałowa, unpubl.); site numbers as in Fig. 1 and ESM Table S1 (available online) 


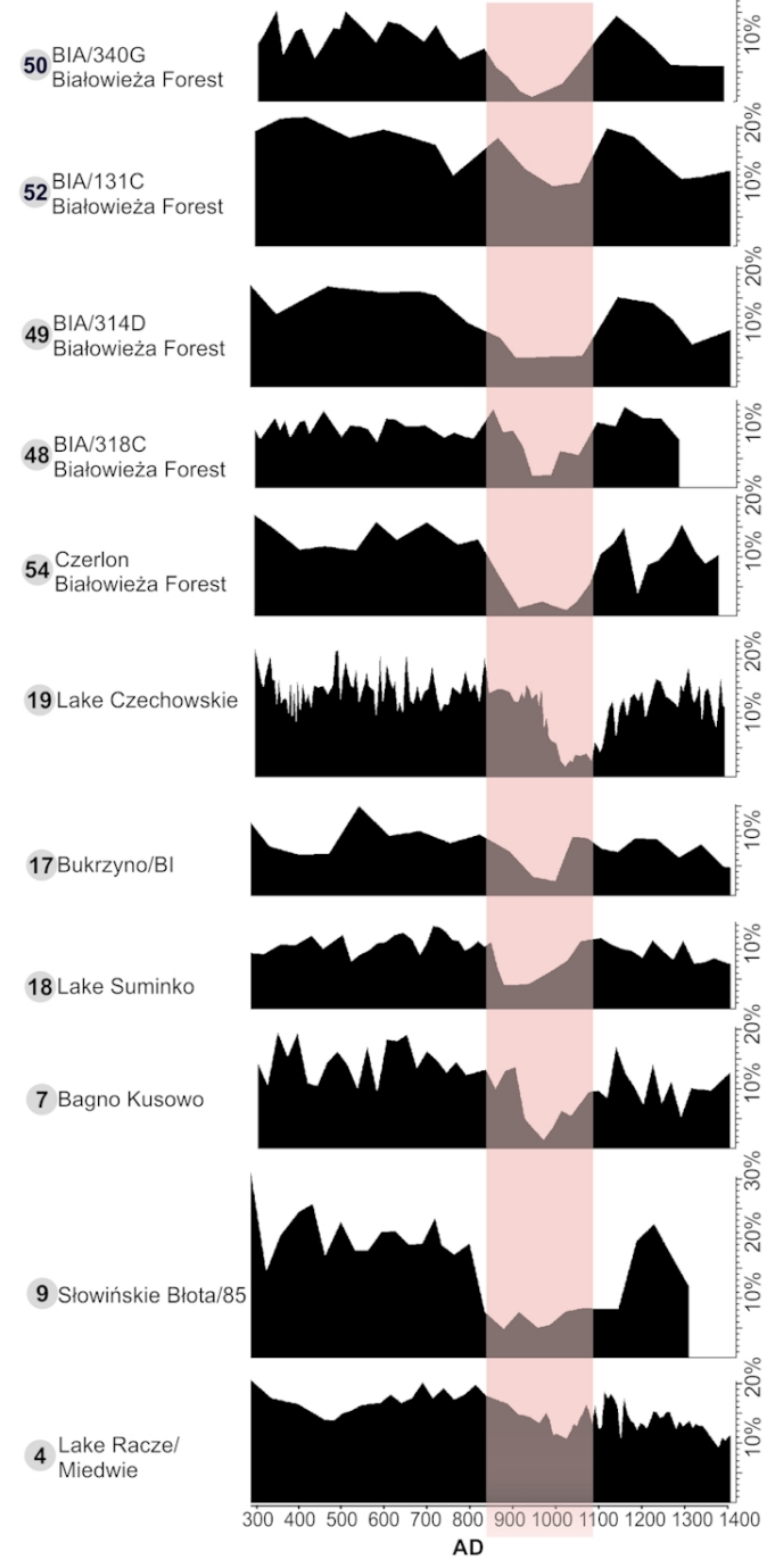

Fig. 4 Alnus pollen percentage values for the period AD 300-1400 in selected sites in Poland: BIA/340G, BIA/131C, BIA/314D and BIA/318C (Zimny, 2014), Czerlon (Latałowa et al., 2016), Lake Czechowskie (Obremska and Ott, unpubl.), Bukrzyno (Pędziszewska, 2008), (Lake Suminko (Pędziszewska et al., 2015), Bagno Kusowo (Lamentowicz et al., 2015), and Słowińskie Błota/85 (Latałowa, unpubl.); Lake Racze/Miedwie (Bloom, 2015); site numbers as in Fig. 1 and ESM Table S1 (available online) 
BIA/340G Białowieża Forest

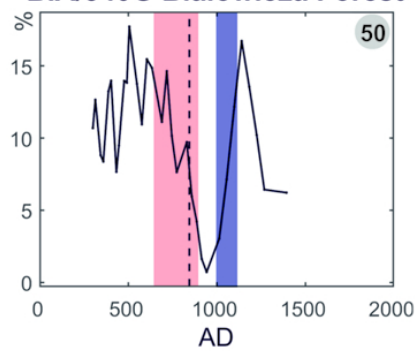

BIA/318C Białowieża Forest

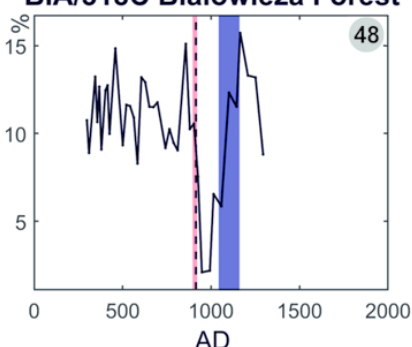

Bukrzyno/BI

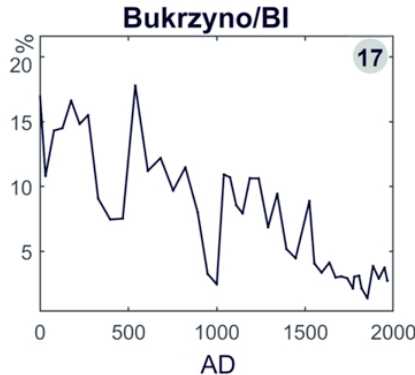

Słowińskie Błota/85

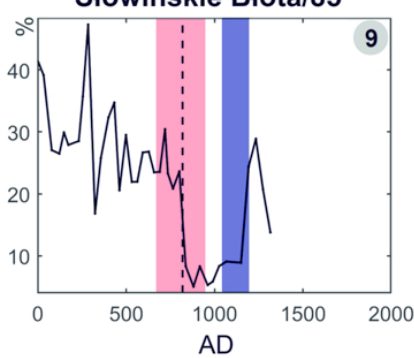

BIA/131C Białowieża Forest

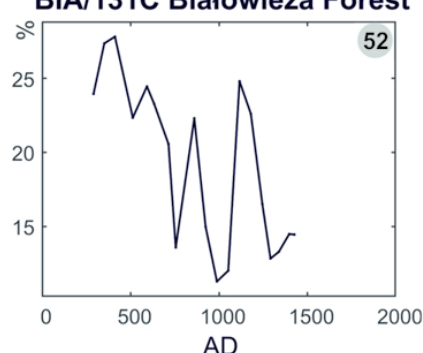

Czerlon Białowieża Forest

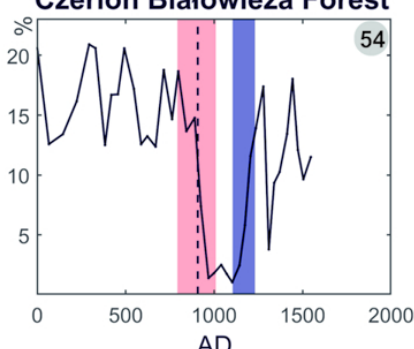

Lake Suminko

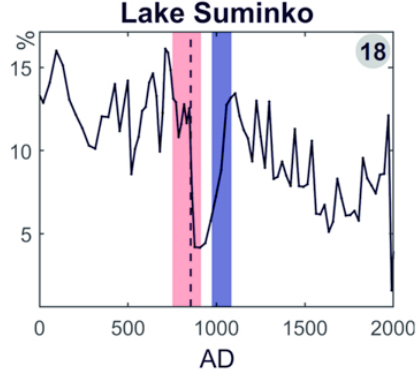

Lake Racze/Miedwie

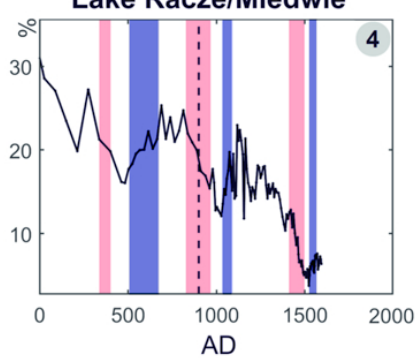

BIA/314D Białowieża Forest

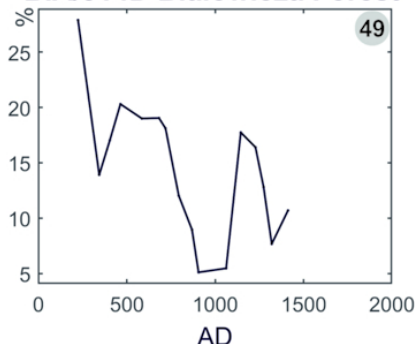

Lake Czechowskie
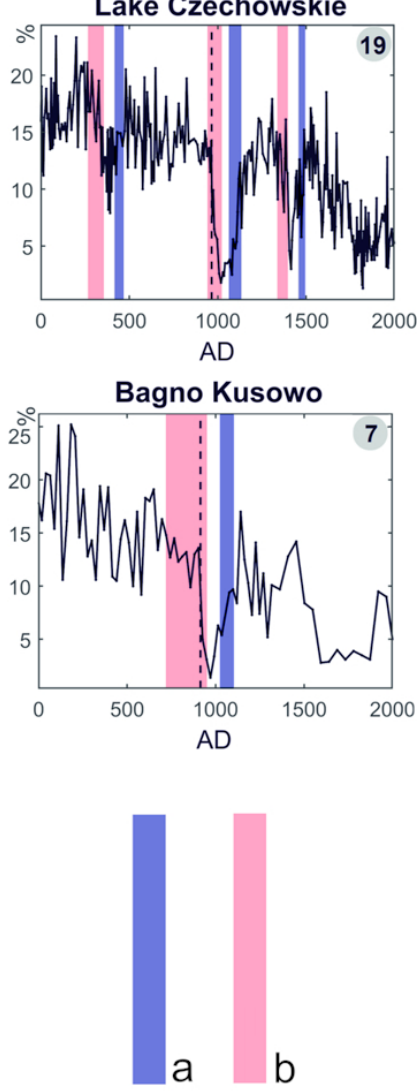

Fig. 5 Analysis of the statistical significance of the decline-rise events in the Alnus populations in 11 selected sites in Poland (see the caption of Fig. 4 for site information) using the SiZer analysis (see ESM Figure S1, available online). a- statistically significant declines, b- statistically significant rises; the strongest decline at

the end of the first millennium is shown with a dashed line. Because the data for three records was too sparse (BIA/131C, BIA/314D and Bukrzyno/BI), no statistically significant decline-rise events were detected 
ESM Table S1 Alnus decline - pollen sites; Site category: A - primary sites, B - secondary sites; Decline: a- present, b- no recovery, c- weak or not recorded; Age of the event (median): start of the decline, minimum value, recovery to the earlier level; EPD - European Pollen Database.

\begin{tabular}{|c|c|c|c|c|c|c|c|c|c|c|c|}
\hline \multirow{2}{*}{$\begin{array}{l}\text { Site } \\
\text { No. }\end{array}$} & \multirow[t]{2}{*}{ Site Name } & \multirow{2}{*}{$\begin{array}{c}\text { Geogr. } \\
\text { coordinates }\end{array}$} & \multirow{2}{*}{$\begin{array}{l}\text { Site } \\
\text { cat. }\end{array}$} & \multicolumn{3}{|c|}{ Decline } & \multirow{2}{*}{$\begin{array}{c}\text { Decline } \\
\text { from-to } \\
(\%)\end{array}$} & \multirow{2}{*}{$\begin{array}{l}\text { Dating } \\
\text { method }\end{array}$} & \multirow{2}{*}{$\begin{array}{c}\text { Age of the } \\
\text { event } \\
\text { (AD) }\end{array}$} & \multirow[t]{2}{*}{ Comment } & \multirow[t]{2}{*}{ Source of data } \\
\hline & & & & & $\mathrm{b}$ & $\mathrm{c}$ & & & & & \\
\hline 1 & $\begin{array}{l}\text { Lake Racze/ } \\
\text { Wolin Island }\end{array}$ & $53^{\circ} 55^{\prime} \mathrm{N} 14^{\circ} 40^{\prime} \mathrm{E}$ & $\mathrm{A}$ & $\mathrm{x}$ & & & $\begin{array}{l}18.5-8.4 \\
(54.6 \%)\end{array}$ & ${ }^{14} \mathrm{C}$ dates & $\begin{array}{c}800 \\
900 \\
1100 \\
\end{array}$ & & Latałowa M (1992) \\
\hline 2 & Kołczewo & $53^{\circ} 55^{\prime} \mathrm{N} 14{ }^{\circ} 40^{\prime} \mathrm{E}$ & A & $\mathrm{X}$ & $x$ & & $\begin{array}{l}26.7-9.7 \\
(63.7 \%)\end{array}$ & ${ }^{14} \mathrm{C}$ dates & $9^{\text {th }} \mathrm{c}$ & $\begin{array}{l}\text { Lack of the top } \\
\text { of the profile }\end{array}$ & Latałowa M (1992) \\
\hline 3 & Wolin II/00 & $53{ }^{\circ} 50 ’ \mathrm{~N} 14{ }^{\circ} 37^{\prime} \mathrm{E}$ & A & $\mathrm{x}$ & & & $\begin{array}{c}10.7-2.1 \\
(80 \%)\end{array}$ & ${ }^{14} \mathrm{C}$ dates & $10^{\text {th }} \mathrm{c}$ & & Pędziszewska A (unpubl.) \\
\hline 4 & Lake Racze/Miedwie & $53^{\circ} 18^{\prime} \mathrm{N} 14^{\circ} 51^{\prime} \mathrm{E}$ & A & $\mathrm{x}$ & & & $\begin{array}{c}20.2-10.8 \\
(46.5 \%)\end{array}$ & ${ }^{14} \mathrm{C}$ dates & $\begin{array}{l}800 \\
975 \\
1070\end{array}$ & & Bloom K (2015) \\
\hline 5 & Lake Zarańskie & $53^{\circ} 34^{\prime} \mathrm{N} 15^{\circ} 49^{\prime} \mathrm{E}$ & $\mathrm{B}$ & $\mathrm{x}$ & & & $20.4-10.6$ & $\begin{array}{l}\text { Pollen } \\
\text { stratigraphy }\end{array}$ & ca. $9-10^{\text {th }} \mathrm{c}$ & & Noryśkiewicz AM (2014) \\
\hline 6 & Lake Gągnowo & $53^{\circ} 37^{\prime} \mathrm{N} 15^{\circ} 48^{\prime} \mathrm{E}$ & A & $\mathrm{x}$ & & & $21-9.3$ & ${ }^{14} \mathrm{C}$ dates & $10^{\text {th }} \mathrm{c}$. & & Noryśkiewicz AM (unpubl.) \\
\hline 7 & Bagno Kusowo & $53^{\circ} 48^{\prime} \mathrm{N} 16^{\circ} 35^{\prime} \mathrm{E}$ & $\mathrm{A}$ & $\mathrm{x}$ & & & $\begin{array}{l}\text { ca. } 13-<5 \\
(61.5 \%)\end{array}$ & ${ }^{14} \mathrm{C}$ dates & $\begin{array}{c}900 \\
950 \\
1100\end{array}$ & & Lamentowicz M et al. (2015) \\
\hline 8 & Lake Kwiecko & $54^{\circ} 01^{\prime} \mathrm{N} 16^{\circ} 42^{\prime} \mathrm{E}$ & $\mathrm{B}$ & $\mathrm{X}$ & & & ca. 30-5 & $\begin{array}{l}\text { Pollen } \\
\text { Stratigraphy }\end{array}$ & $9-10^{\text {th }} \mathrm{c}$ & & Madeja J (2012) \\
\hline 9 & Słowińskie Błota/85 & $54^{\circ} 25^{\prime} \mathrm{N} 16^{\circ} 30^{\prime} \mathrm{E}$ & $\mathrm{A}$ & $\mathrm{X}$ & & & $\begin{array}{l}24.2-4.9 \\
(79.8 \%)\end{array}$ & ${ }^{14} \mathrm{C}$ dates & $\begin{array}{l}860 \\
960 \\
1170\end{array}$ & & Latałowa M (unpubl.) \\
\hline 10 & Kluki & $54^{\circ} 42^{\prime} \mathrm{N} 17^{\circ} 17^{\prime} \mathrm{E}$ & A & $\mathrm{X}$ & & & $\begin{array}{c}20.6-3.7 \\
(82 \%)\end{array}$ & ${ }^{14} \mathrm{C}$ dates & $9-10^{\text {th }} \mathrm{c}$. & & Tobolski K (1987); EPD \\
\hline 11 & Darżlubie Forest & $54^{\circ} 42^{\prime} \mathrm{N} 18^{\circ} 10^{\prime} \mathrm{E}$ & $\mathrm{A}$ & $\mathrm{x}$ & $\mathrm{x}$ & & $(61.1 \%)$ & ${ }^{14} \mathrm{C}$ dates & $10^{\text {th }} \mathrm{c}$. & $\begin{array}{l}\text { Lack of the top } \\
\text { of the profile }\end{array}$ & Latałowa M (1982) \\
\hline 12 & Gołębiewo/GI & $54^{\circ} 27^{\prime} \mathrm{N} 18^{\circ} 30^{\prime} \mathrm{E}$ & $\mathrm{A}$ & $\mathrm{x}$ & & & $\begin{array}{l}11.2-3.2 \\
(71.43 \%)\end{array}$ & ${ }^{14} \mathrm{C}$ dates & 1040 & & $\begin{array}{c}\text { Pędziszewska A and Latałowa } \\
\text { M (2016) }\end{array}$ \\
\hline
\end{tabular}




\begin{tabular}{|c|c|c|c|c|c|c|c|c|c|}
\hline $\begin{array}{l}\text { Site } \\
\text { No. }\end{array}$ & Site Name & $\begin{array}{c}\text { Geogr. } \\
\text { coordinates }\end{array}$ & $\begin{array}{l}\text { Site } \\
\text { cat. }\end{array}$ & Decline & $\begin{array}{l}\text { Decline } \\
\text { from-to } \\
(\%)\end{array}$ & $\begin{array}{l}\text { Dating } \\
\text { method }\end{array}$ & $\begin{array}{c}\text { Age of the } \\
\text { event } \\
\text { (AD) }\end{array}$ & Comment & Source of data \\
\hline 13 & $\begin{array}{l}\text { Gdańsk-Pszenna } \\
\text { Granary Island }\end{array}$ & $54^{\circ} 20^{\prime} \mathrm{N} 18^{\circ} 39^{\prime} \mathrm{E}$ & A & $\mathrm{x}$ & $\begin{array}{c}44.1-2.2 \\
(95 \%)\end{array}$ & ${ }^{14} \mathrm{C}$ dates & $\begin{array}{c}880 \\
940 \\
1200\end{array}$ & $\begin{array}{l}\text { A hiatus } \\
\text { around the } \\
\text { decline }\end{array}$ & $\begin{array}{l}\text { Święta-Musznicka J and } \\
\text { Latałowa M (2016) }\end{array}$ \\
\hline 14 & $\begin{array}{l}\text { Gdańsk-Żytnia } \\
\text { Granary Island }\end{array}$ & $54^{\circ} 20^{\prime} \mathrm{N} 18^{\circ} 39^{\prime} \mathrm{E}$ & A & $\mathrm{X}$ & $\begin{array}{l}49.5-3.7 \\
(92.5 \%)\end{array}$ & ${ }^{14} \mathrm{C}$ dates & $9-10^{\text {th }} \mathrm{c}$. & & $\begin{array}{l}\text { Swięta-Musznicka J and } \\
\text { Latałowa M (2016) }\end{array}$ \\
\hline 15 & Lake Godziszewskie & $54^{\circ} 5^{\prime} \mathrm{N} 18^{\circ} 33^{\prime} \mathrm{E}$ & $\mathrm{B}$ & $\mathrm{x}$ & $\begin{array}{l}30.1-3.8 \\
(87.4 \%)\end{array}$ & $\begin{array}{l}\text { Pollen } \\
\text { stratigraphy }\end{array}$ & ca. $9-10^{\text {th }} \mathrm{c}$ & & Miotk G (1986); EPD \\
\hline 16 & Stążki/2013 & $54^{\circ} 25^{\prime} \mathrm{N} 18^{\circ} 05^{\prime} \mathrm{E}$ & $\mathrm{B}$ & $\mathrm{X}$ & $\begin{array}{c}\text { ca. } 15-2 \\
(87 \%)\end{array}$ & $\begin{array}{l}\text { Age/depth } \\
\text { model }\end{array}$ & ca. $10^{\text {th }} \mathrm{c}$. & & Gałka M et al. (2013) \\
\hline $16 a$ & Stążki/2008 & $54^{\circ} 25^{\prime} \mathrm{N} 18^{\circ} 05^{\prime} \mathrm{E}$ & A & $\mathrm{x}$ & $\begin{array}{l}\text { ca. } 10-3 \\
(\text { ca. } 70 \%)\end{array}$ & ${ }^{14} \mathrm{C}$ dates & $10^{\text {th }} \mathrm{c}$. & & Lamentowicz M et al. (2008a) \\
\hline 17 & Bukrzyno/BI & $54^{\circ} 14^{\prime} \mathrm{N} 18^{\circ} 01^{\prime} \mathrm{E}$ & A & $\mathrm{x}$ & $\begin{array}{l}10.3-2.4 \\
(76,7 \%)\end{array}$ & ${ }^{14} \mathrm{C}$ dates & $\begin{array}{c}890 \\
1000 \\
1040 \\
\end{array}$ & & Pędziszewska A (2008) \\
\hline 18 & Lake Suminko & $54^{\circ} 11^{\prime} \mathrm{N} 17^{\circ} 47^{\prime} \mathrm{E}$ & A & $\mathrm{X}$ & $\begin{array}{l}11.1-4 \\
(64 \%)\end{array}$ & ${ }^{14} \mathrm{C}$ dates & $\begin{array}{r}860 \\
940 \\
1060 \\
\end{array}$ & & Pędziszewska A et al. (2015) \\
\hline 19 & Lake Czechowskie & $53^{\circ} 52^{\prime} \mathrm{N} 18^{\circ} 14^{\prime} \mathrm{E}$ & $\mathrm{A}$ & $\mathrm{x}$ & $\begin{array}{c}14.5-1.8 \\
(88 \%)\end{array}$ & $\begin{array}{l}{ }^{14} \mathrm{C} \text { dates } \\
\text { varves }\end{array}$ & $\begin{array}{l}969 \\
1024 \\
1135\end{array}$ & & this paper \\
\hline 20 & Lake Wielkie Gacno & $53^{\circ} 47^{\prime} \mathrm{N} 17^{\circ} 30^{\prime} \mathrm{E}$ & $\mathrm{B}$ & & - & $\begin{array}{l}\text { Age/depth } \\
\text { model }\end{array}$ & - & $\begin{array}{l}\text { The event } \\
\text { unclear }\end{array}$ & Hjelmroos-Ericksson M (1981) \\
\hline 21 & Lake Ostrowite & $53^{\circ} 47^{\prime} \mathrm{N} 17^{\circ} 35^{\prime} \mathrm{E}$ & $\mathrm{B}$ & & - & $\begin{array}{l}\text { Age/depth } \\
\text { model }\end{array}$ & - & $\begin{array}{l}\text { The event } \\
\text { unclear }\end{array}$ & Milecka K (2005) \\
\hline 22 & Lake Suszek & $53^{\circ} 43^{\prime} \mathrm{N} 17^{\circ} 46^{\prime} \mathrm{E}$ & B & $\mathrm{X}$ & $\begin{array}{l}\text { ca. } 22-12 \\
(45.5 \%)\end{array}$ & $\begin{array}{c}\text { Pollen } \\
\text { stratigraphy }\end{array}$ & ca. $9-10^{\text {th }} \mathrm{c}$. & & Miotk-Szpiganowicz G (1992) \\
\hline 23 & Tuchola & $53^{\circ} 34^{\prime} \mathrm{N} 17^{\circ} 54^{\prime} \mathrm{E}$ & $\mathrm{B}$ & $\mathrm{x}$ & $(75 \%)$ & $\begin{array}{l}\text { Pollen } \\
\text { stratigraphy }\end{array}$ & $9-10^{\text {th }} \mathrm{c}$ & "One sample & Lamentowicz M et al. (2008b) \\
\hline 24 & Lake Kęsowo & $53^{\circ} 33^{\prime} \mathrm{N} 17^{\circ} 43^{\prime} \mathrm{E}$ & B & $\mathrm{X}$ & $\begin{array}{l}\text { ca. } 20-11 \\
(45 \%)\end{array}$ & $\begin{array}{c}\text { Pollen } \\
\text { stratigraphy }\end{array}$ & $9-10^{\text {th }} \mathrm{c}$. & & Miotk-Szpiganowicz G (1992) \\
\hline 25 & Lake Jelonek & $53^{\circ} 45^{\prime} \mathrm{N} 18^{\circ} 23^{\prime} \mathrm{E}$ & B & $\mathrm{x}$ & $\begin{array}{l}\text { ca. } 10-3 \\
(70 \%)\end{array}$ & $\begin{array}{c}\text { Pollen } \\
\text { stratigraphy }\end{array}$ & ca. $9^{\text {th }} \mathrm{c}$. & & Filbrandt-Czaja A (2009) \\
\hline
\end{tabular}




\begin{tabular}{|c|c|c|c|c|c|c|c|c|c|}
\hline $\begin{array}{l}\text { Site } \\
\text { No. }\end{array}$ & Site Name & $\begin{array}{c}\text { Geogr. } \\
\text { coordinates }\end{array}$ & $\begin{array}{l}\text { Site } \\
\text { cat. }\end{array}$ & Decline & $\begin{array}{l}\text { Decline } \\
\text { from-to } \\
(\%)\end{array}$ & $\begin{array}{l}\text { Dating } \\
\text { method }\end{array}$ & $\begin{array}{c}\text { Age of the } \\
\text { event } \\
\text { (AD) }\end{array}$ & Comment & Source of data \\
\hline 26 & Zawada & $53^{\circ} 37^{\prime} \mathrm{N} 18^{\circ} 35^{\prime} \mathrm{E}$ & $\mathrm{B}$ & $\mathrm{x}$ & $\begin{array}{c}17.8-11,4 \\
(36 \%)\end{array}$ & $\begin{array}{c}\text { Pollen } \\
\text { stratigraphy }\end{array}$ & ca. $9-10^{\text {th }} \mathrm{c}$. & $\begin{array}{l}\text { A hiatus } \\
\text { around the } \\
\text { decline }\end{array}$ & Noryśkiewicz B (2004) \\
\hline 27 & Lake Mukrz I & $53^{\circ} 31^{\prime} \mathrm{N} 18^{\circ} 07^{\prime} \mathrm{E}$ & $\mathrm{B}$ & $\mathrm{x}$ & $\begin{array}{c}19.6-10.2 \\
(48 \%)\end{array}$ & $\begin{array}{c}\text { Pollen } \\
\text { stratigraphy }\end{array}$ & ca. $9-10^{\text {th }} \mathrm{c}$ & & Noryśkiewicz AM (2006) \\
\hline 28 & Gruczno & $53^{\circ} 22^{\prime} \mathrm{N} 18^{\circ} 19^{\prime} \mathrm{E}$ & $\mathrm{B}$ & $\mathrm{x}$ & $\begin{array}{c}19-3.7 \\
(80.5 \%)\end{array}$ & $\begin{array}{c}\text { Pollen } \\
\text { stratigraphy }\end{array}$ & ca. $9^{\text {th }} c$. & & Noryśkiewicz AM (2016) \\
\hline 29 & Lake Czyste & $53^{\circ} 17^{\prime} \mathrm{N} 18^{\circ} 29^{\prime} \mathrm{E}$ & A & $\mathrm{x}$ & $\begin{array}{l}12.9-4,8 \\
(62.8 \%)\end{array}$ & ${ }^{14} \mathrm{C}$ dates & $\begin{array}{l}770 \\
820 \\
850\end{array}$ & & Noryśkiewicz AM (2013) \\
\hline 30 & Lake Mełno & $53^{\circ} 26^{\prime} \mathrm{N} \mathrm{19} 00^{\circ} \mathrm{E}$ & B & $\mathrm{x}$ & $\begin{array}{l}20.5-5,2 \\
(74.1 \%)\end{array}$ & $\begin{array}{c}\text { Pollen } \\
\text { stratigraphy }\end{array}$ & $9-10^{\text {th }} \mathrm{c}$. & & Noryśkiewicz AM (2013) \\
\hline 31 & Linje & 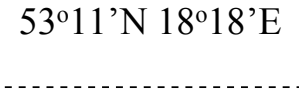 & B & $\mathrm{x}$ & $\begin{array}{c}17.9-4 \\
(77.7 \%)\end{array}$ & $\begin{array}{c}\text { Pollen } \\
\text { stratigraphy }\end{array}$ & $10^{\text {th }} \mathrm{c}$. & & Noryśkiewicz AM (2013) \\
\hline $31 \mathrm{a}$ & Linje & $53^{\circ} 11^{\prime} \mathrm{N} 18^{\circ} 18^{\prime} \mathrm{E}$ & A & $\mathrm{x}$ & $\begin{array}{l}\text { ca. } 16-8 \\
(50 \%)\end{array}$ & ${ }^{14} \mathrm{C}$ dates & $9-10^{\text {th }} \mathrm{c}$ & & Marcisz K et al. (2015) \\
\hline 32 & Lake Kamionkowskie & $53^{\circ} 08^{\prime} \mathrm{N} 18^{\circ} 46^{\prime} \mathrm{E}$ & $\mathrm{B}$ & $\mathrm{x}$ & $\begin{array}{r}14.7-5,5 \\
(62.6 \%)\end{array}$ & $\begin{array}{c}\text { Pollen } \\
\text { stratigraphy }\end{array}$ & ca. $10^{\text {th }} \mathrm{c}$ & & Noryśkiewicz AM (2013) \\
\hline 33 & Gronowo & $53^{\circ} 06^{\prime} \mathrm{N} 18^{\circ} 48^{\prime} \mathrm{E}$ & A & $\mathrm{x}$ & $\begin{array}{l}15.5-3,6 \\
(76.8 \%)\end{array}$ & ${ }^{14} \mathrm{C}$ dates & $\begin{array}{c}880 \\
990 \\
1210\end{array}$ & & Noryśkiewicz AM (2013) \\
\hline 34 & Lake Strażym & $53^{\circ} 20^{\prime} \mathrm{N} 19^{\circ} 27^{\prime} \mathrm{E}$ & $\mathrm{B}$ & $\mathrm{x}$ & $\begin{array}{r}19.2-4,5 \\
(76.6 \%)\end{array}$ & $\begin{array}{c}\text { Pollen } \\
\text { stratigraphy }\end{array}$ & ca. $9-10^{\text {th }} \mathrm{c}$. & & Noryśkiewicz B (1987); EPD \\
\hline 35 & Lake Zwiniarz & $53^{\circ} 26^{\prime} \mathrm{N} 19^{\circ} 50^{\prime} \mathrm{E}$ & $\mathrm{B}$ & $\mathrm{x}$ & $\begin{array}{c}19.3-5,6 \\
(71 \%)\end{array}$ & $\begin{array}{c}\text { Pollen } \\
\text { stratigraphy }\end{array}$ & ca. $9-10^{\text {th }} \mathrm{c}$ & $\begin{array}{c}\text { One sample } \\
\text { event" }\end{array}$ & Noryśkiewicz A (unpubl.) \\
\hline 36 & Gązwa & $53^{\circ} 52^{\prime} \mathrm{N} 21^{\circ} 13^{\prime} \mathrm{E}$ & A & $\mathrm{x}$ & $\begin{array}{c}\text { ca. } 15-3 \\
(80 \%)\end{array}$ & ${ }^{14} \mathrm{C}$ dates & ca. $8^{\text {th }} \mathrm{c}$ & $\begin{array}{c}\text { "One sample } \\
\text { event" }\end{array}$ & Gałka M et al. (2015) \\
\hline 37 & Lake Salęt & $53^{\circ} 56^{\prime} \mathrm{N} 21^{\circ} 19^{\prime} \mathrm{E}$ & B & $\mathrm{x}$ & - & ${ }^{14} \mathrm{C}$ dates & - & - & Szal M et al. (2014) \\
\hline 38 & Lake Mikołajki & $53^{\circ} 46^{\prime} \mathrm{N} 21^{\circ} 35^{\prime} \mathrm{E}$ & $\mathrm{B}$ & $x$ & - & $\begin{array}{c}\text { Pollen } \\
\text { stratigraphy }\end{array}$ & - & $\begin{array}{c}\text { Slight decline } \\
\text { difficult to } \\
\text { date }\end{array}$ & $\begin{array}{c}\text { Ralska-Jasiewiczowa M (1966); } \\
\text { EPD }\end{array}$ \\
\hline
\end{tabular}




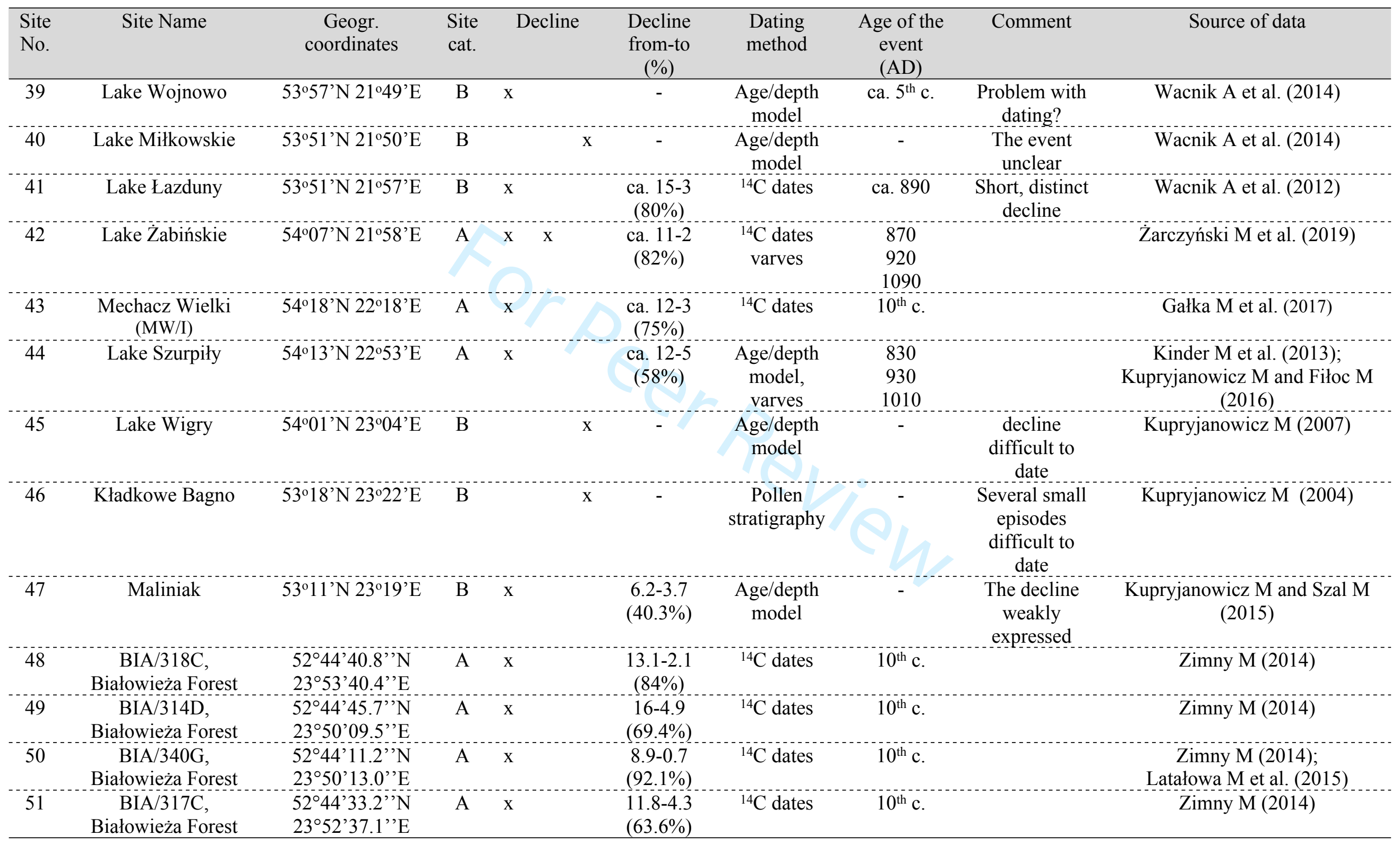




\begin{tabular}{|c|c|c|c|c|c|c|c|c|c|}
\hline $\begin{array}{l}\text { Site } \\
\text { No. }\end{array}$ & Site Name & $\begin{array}{c}\text { Geogr. } \\
\text { coordinates }\end{array}$ & $\begin{array}{l}\text { Site } \\
\text { cat. }\end{array}$ & Decline & $\begin{array}{c}\text { Decline } \\
\text { from-to } \\
(\%)\end{array}$ & $\begin{array}{l}\text { Dating } \\
\text { method }\end{array}$ & $\begin{array}{c}\text { Age of the } \\
\text { event } \\
\text { (AD) }\end{array}$ & Comment & Source of data \\
\hline 52 & $\begin{array}{c}\text { BIA/131C, } \\
\text { Białowieża Forest }\end{array}$ & $\begin{array}{l}52^{\circ} 47^{\prime} 59.5^{\prime}, \mathrm{N} \\
23^{\circ} 50^{\prime} 51.3^{\prime \prime} \mathrm{E}\end{array}$ & A & $\mathrm{x}$ & $\begin{array}{c}18.2-10.1 \\
(44.5 \%)\end{array}$ & ${ }^{14} \mathrm{C}$ dates & $10^{\text {th }} \mathrm{c}$ & & $\begin{array}{l}\text { Zimny M (2014); Latałowa M et } \\
\text { al. }(2015,2016)\end{array}$ \\
\hline 53 & $\begin{array}{l}\mathrm{BIA} / 161 \mathrm{~A}, \\
\text { Białowieża Forest }\end{array}$ & $\begin{array}{l}52^{\circ} 47^{\prime} 55.0^{\prime}, \mathrm{N} \\
23^{\circ} 50^{\prime} 48.7^{\prime} \mathrm{E}\end{array}$ & A & $\mathrm{x}$ & - & ${ }^{14} \mathrm{C}$ dates & $10^{\text {th }} \mathrm{c}$. & $\begin{array}{l}\text { The decline } \\
\text { unclear; } \\
\text { sediment } \\
\text { disturbances }\end{array}$ & Pędziszewska A (unpubl.) \\
\hline 54 & Czerlon & $\begin{array}{l}52^{\circ} 411^{\prime} 17.8^{\prime}, \mathrm{N} \\
23^{\circ} 444^{\prime} 09.2^{\prime} \mathrm{E}\end{array}$ & A & $\mathrm{x}$ & $(89.1 \%)$ & ${ }^{14} \mathrm{C}$ dates & $10^{\text {th }} \mathrm{c}$. & & Latałowa M et al. (2016) \\
\hline 55 & Lake Błędowo & $52^{\circ} 32^{\prime} \mathrm{N} 20^{\circ} 40^{\prime} \mathrm{E}$ & $\mathrm{B}$ & $\mathrm{x}$ & $\begin{array}{l}14.1-7.5 \\
(46.8 \%)\end{array}$ & $\begin{array}{l}\text { Pollen } \\
\text { stratigraphy }\end{array}$ & ca. $9-10^{\text {th }} \mathrm{c}$ & & Bińka K et al. (1991); EPD \\
\hline 56 & Lake Gościąż & $52^{\circ} 35^{\prime} \mathrm{N} 19^{\circ} 21^{\prime} \mathrm{E}$ & $\mathrm{B}$ & $\mathrm{x}$ & $\begin{array}{l}18.8-11.8 \\
(37.2 \%)\end{array}$ & ${ }^{14} \mathrm{C}$ dates & ca. $9-10^{\text {th }} \mathrm{c}$ & $\begin{array}{l}\text { Weak data in } \\
\text { the section of } \\
\text { the Alnus } \\
\text { decline }\end{array}$ & $\begin{array}{l}\text { Ralska-Jasiewiczowa M et al. } \\
\text { (1998); EPD }\end{array}$ \\
\hline 57 & Lake Białe & $52^{\circ} 29^{\prime} \mathrm{N} 19^{\circ} 31^{\prime} \mathrm{E}$ & B & $\mathrm{x}$ & - & $\begin{array}{l}\text { Age/depth } \\
\text { model }\end{array}$ & ca. $10^{\text {th }} \mathrm{c}$. & $\begin{array}{l}\text { Weak data in } \\
\text { the section of } \\
\text { the Alnus } \\
\text { decline }\end{array}$ & Wacnik A et al. (2011) \\
\hline 58 & Lake Steklin & $52^{\circ} 57^{\prime} \mathrm{N} 19^{\circ} 01^{\prime} \mathrm{E}$ & $\mathrm{B}$ & $x$ & - & $\begin{array}{l}\text { Pollen } \\
\text { Stratigraphy }\end{array}$ & & $\begin{array}{l}\text { The event } \\
\text { unclear }\end{array}$ & Noryśkiewicz B (1982); EPD \\
\hline 59 & Lake Gopło & $52^{\circ} 38^{\prime} \mathrm{N} 18^{\circ} 21^{\prime} \mathrm{E}$ & $\mathrm{B}$ & $\mathrm{x}$ & $\begin{array}{l}12.5-4.7 \\
(62.4 \%)\end{array}$ & $\begin{array}{c}\text { Pollen } \\
\text { stratigraphy }\end{array}$ & ca. $9-10^{\text {th }} \mathrm{c}$. & & Jankowska B (1980) \\
\hline 60 & Lake Kamionek & $52^{\circ} 35^{\prime} \mathrm{N} 17^{\circ} 23^{\prime} \mathrm{E}$ & $\mathrm{B}$ & $\mathrm{x}$ & $\begin{array}{l}\text { ca. } 22-10 \\
(50.5 \%)\end{array}$ & $\begin{array}{l}\text { Pollen } \\
\text { stratigraphy }\end{array}$ & ca. $9-10^{\text {th }}$ & & Filbrandt-Czaja A (1998) \\
\hline 61 & Lake Skrzetuszewskie & $52^{\circ} 33^{\prime} \mathrm{N} 17^{\circ} 21^{\prime} \mathrm{E}$ & $\mathrm{B}$ & $x$ & - & ${ }^{14} \mathrm{C}$ dates & - & $\begin{array}{l}\text { The event } \\
\text { unclear }\end{array}$ & Tobolski K (1991); EPD \\
\hline 62 & $\begin{array}{l}\text { Lake Lednica } \\
\text { I/86 }\end{array}$ & $52^{\circ} 33^{\prime} \mathrm{N} 17^{\circ} 23^{\prime} \mathrm{E}$ & B & $\mathrm{x}$ & $\begin{array}{l}17.02-7.6 \\
(58.3 \%)\end{array}$ & $\begin{array}{l}\text { Pollen } \\
\text { stratigraphy }\end{array}$ & ca. $9-10^{\text {th }} \mathrm{c}$. & & Makohonienko M (1991); EPD \\
\hline 63 & Lake Głęboczek & $52^{\circ} 39^{\prime} \mathrm{N} 17^{\circ} 38^{\prime} \mathrm{E}$ & $\mathrm{B}$ & $\mathrm{x}$ & $\begin{array}{c}\text { ca. } 19-7 \\
(63 \%)\end{array}$ & $\begin{array}{c}\text { Pollen } \\
\text { stratigraphy }\end{array}$ & ca. $9-10^{\text {th }} \mathrm{c}$ & & Makohonienko M (2000) \\
\hline 64 & Lake Swiętokrzyskie & $52^{\circ} 32^{\prime} \mathrm{N} 17^{\circ} 35^{\prime} \mathrm{E}$ & $\mathrm{B}$ & $\mathrm{x}$ & $\begin{array}{l}21.5-6.1 \\
(71.6 \%)\end{array}$ & $\begin{array}{c}\text { Pollen } \\
\text { stratigraphy }\end{array}$ & ca. $9-10^{\text {th }} \mathrm{c}$ & & Makohonienko M (2000); EPD \\
\hline
\end{tabular}




\begin{tabular}{|c|c|c|c|c|c|c|c|c|c|c|}
\hline $\begin{array}{l}\text { Site } \\
\text { No. }\end{array}$ & Site Name & $\begin{array}{c}\text { Geogr. } \\
\text { coordinates }\end{array}$ & $\begin{array}{l}\text { Site } \\
\text { cat. }\end{array}$ & & Decline & $\begin{array}{l}\text { Decline } \\
\text { from-to } \\
(\%)\end{array}$ & $\begin{array}{l}\text { Dating } \\
\text { method }\end{array}$ & $\begin{array}{c}\text { Age of the } \\
\text { event } \\
\text { (AD) }\end{array}$ & Comment & Source of data \\
\hline 65 & Lake Baba & $52^{\circ} 25^{\prime} \mathrm{N} 17^{\circ} 22^{\prime} \mathrm{E}$ & $\mathrm{B}$ & & 2 & - & $\begin{array}{c}\text { Pollen } \\
\text { stratigraphy }\end{array}$ & - & $\begin{array}{l}\text { The event } \\
\text { unclear }\end{array}$ & Milecka K (1998) \\
\hline 66 & Giecz 4/90 & $52^{\circ} 19^{\prime} \mathrm{N} 17^{\circ} 21^{\prime} \mathrm{E}$ & B & $\mathrm{x}$ & $\mathrm{x}$ & $\begin{array}{c}\text { ca. } 28-12 \\
(57.1 \%)\end{array}$ & $\begin{array}{l}\text { Pollen } \\
\text { stratigraphy }\end{array}$ & ca. $9-10^{\text {th }} \mathrm{c}$ & & Milecka K (1998) \\
\hline 67 & Lake Wonieść & $51^{\circ} 59^{\prime} \mathrm{N} 16^{\circ} 42^{\prime} \mathrm{E}$ & A & $\mathrm{x}$ & & ca. 16-5 & $\begin{array}{l}\text { Age/depth } \\
\text { model }\end{array}$ & ca. $9^{\text {th }} \mathrm{c}$. & & Dörfler W (2011) \\
\hline 68 & $\begin{array}{c}\text { Lake Paklicko } \\
\text { Wielkie }\end{array}$ & $52^{\circ} 19^{\prime} \mathrm{N} 15^{\circ} 30^{\prime} \mathrm{E}$ & $\mathrm{B}$ & $\mathrm{x}$ & & $\begin{array}{l}13.8-4.3 \\
(69 \%)\end{array}$ & ${ }^{14} \mathrm{C}$ dates & $10^{\text {th }} \mathrm{c}$ & & Noryśkiewicz AM (unpubl.) \\
\hline 69 & Lake Długie & $52^{\circ} 28^{\prime} \mathrm{N} 15^{\circ} 26^{\prime} \mathrm{E}$ & B & $\mathrm{x}$ & & $\begin{array}{c}18.8-4.1 \\
(78 \%)\end{array}$ & $\begin{array}{l}\text { Pollen } \\
\text { stratigraphy }\end{array}$ & $10^{\text {th }} \mathrm{c}$. & & Noryśkiewicz AM (unpubl.) \\
\hline
\end{tabular}

\section{References}

Bińka K, Cieśla A, Łącka B et al. (1991) The development of Błędowo Lake (central Poland) - a palaeoecological study. Studia Geologica Polonica 100: 7-85.

Bloom K (2015) Wplyw czynników naturalnych i gospodarki pradziejowej na sukcesję roślinności w rejonie Jeziora Raczego na Ziemi Pyrzyckiej w holocenie. Studium paleoekologiczne. PhD Thesis, University of Gdańsk, Poland.

Dörfler W (2011) Paleoecological reconstruction of the Bronze Age landscape around Lake Wonieść, Great Poland. In: Hildebrandt-Radke I, Czebraszuk J, Dölfler W and Müller J (eds) Anthropogenic pressure in the Neolithic and Bronze Age in the central-European Lowlands. Poznań: Bogucki Wydawnictwo Naukowe \& Bonn, Germany: Dr. Rudolf Habelt GmbH, Studien zur Archäologie in Ostmitteleuropa 8, pp.67-77.

Filbrandt-Czaja A (1998) Historia roślinności północnej części Lednickiego Parku Krajobrazowego ze szczególnym uwzględnieniem czynnika antropogenicznego. Biblioteka Studiów Lednickich 3: 9-41.

Filbrandt-Czaja A (2009) Studia nad historia szaty roślinnej i krajobrazu Borów Tucholskich. Toruń: Wydawnictwo Naukowe Uniwersytetu Mikołaja Kopernika.

Gałka M, Miotk-Szpiganowicz G, Goslar T et al. (2013) Palaeohydrology, fires and vegetation succession in the southern Baltic during the last 7500 years reconstructed from a raised bog based on multi-proxy data. Palaeogeography, Palaeoclimatology, Palaeoecology 370: $209-221$.

Gałka M, Miotk-Szpiganowicz G, Marczewska M et al. (2015) Palaeoenvironmental changes in Central Europe (NE Poland) during the last 6200 years reconstructed from a high-resolution multi-proxy peat archive. The Holocene 25: 421-434. 
Gałka M, Tobolski K, Lamentowicz $Ł$ et al. (2017) Unveiling exceptional Baltic bog ecohydrology, autogenic succession and climate change during the last 2000 years in CE Europe using replicate cores, multi-proxy data and functional traits of testate amoebae. Quaternary Science Reviews 156: $90-106$.

Hjelmroos-Ericsson M (1981) Holocene development of Lake Wielkie Gacno area, northwestern Poland. PhD Thesis, 10, Lund University, Sweden.

Jankowska B (1980) Szata roślinna okolic Gopła w późnym glacjale i holocenie oraz wpływ osadnictwa na jej rozwój w świetle badań paleobotanicznych. Przegląd Archeologiczny 27: 5-41.

Kinder M, Tylmann W, Enters D et al. (2013) Construction and validation of calendar-year time scale for annually laminated sediments - an example from Lake Szurpily (NE Poland). GFF 135: 248-257.

Kupryjanowicz M (2004) The vegetation changes recorded in sediments of Kładkowe Bagno peat bog in Puszcza Knyszyńska Forest, north-eastern Poland. Acta Palaeobotanica 44: 175-193.

Kupryjanowicz M (2007) Postglacial development of vegetation in the vicinity of the Wigry lake. Geochronometria 27: 53-66.

Kupryjanowicz M and Fiłoc M (2016) Badania palinologiczne Jaćwieży. In: Bitner-Wróblewska A, Brzeziński W and Kasprzycka M (eds) Archeologia Jaćwieży. Dawne badania i nowe perspektywy. Warszawa: Państwowe Muzeum Archeologiczne, Stowarzyszenie Starożytników, pp.133-157.

Kupryjanowicz M and Szal M (2015) Palinologiczne ślady osadnictwa prehistorycznego w centralnej części Puszczy Knyszyńskiej. In: Wawrusiewicz A, Januszek K and Manasterski D (eds) Obiekty obrzędowe Pucharów Dzwonowatych z Supraśla. Złożenie darów - przejęcie terenu czy integracja kulturowa? Białystok: Muzeum Podlaskie w Białymstoku, pp.225-241.

Lamentowicz M, Gałka M, Lamentowicz $€$ et al. (2015) Reconstructing climate change and ombrotrophic bog development during the last 4000 years in northern Poland using biotic proxies, stable isotopes and trait-based approach. Palaeogeography, Palaeoclimatology, Palaeoecology 418: 261-277.

Lamentowicz M, Obremska M and Mitchell E (2008a) Autogenic succession, land-use change, and climatic influences on the Holocene development of a kettle-hole mire in Northern Poland. Review of Palaeobotany and Palynology 151: 21-40.

Lamentowicz M, Cedro A, Gałka M et al. (2008b) Last millennium palaeoenvironmental changes from a Baltic bog (Poland) inferred from stable isotopes, pollen, plant macrofossils and testate amoebae. Palaeogeography, Palaeoclimatology, Palaeoecology 265: 93-106.

Latałowa M (1982) Postglacial vegetational changes in the eastern Baltic coastal zone of Poland. Acta Palaeobotanica 22: 179-249.

Latałowa M (1992) Man and vegetation in the pollen diagrams from Wolin Island (NW Poland). Acta Palaeobotanica 32: $123-249$.

Latałowa M, Zimny M, Jędrzejewska B et al. (2015) Białowieża Primeval Forest: A 2000-year Interplay of Environmental and Cultural Forces in Europe's Best Preserved Temperate Woodland. In: Kirby KJ and Watkins C (eds) Europe's Changing Woods and Forests: From Wildwood to Managed Landscapes. Wallingford: CAB International, pp.243-264.

Latałowa M, Zimny M, Pędziszewska A et al. (2016) Postglacjalna historia Puszczy Białowieskiej - roślinność, klimat i działalność człowieka. Parki Narodowe i Rezerwaty Przyrody 35: 3-49. 
Madeja J (2012) Local Holocene vegetation changes and settlement history based on pollen analysis of Lake Kwiecko sediments, West-Pomeranian Lake District, NW Poland. Acta Palaeobotanica 52: 105-125.

Makohonienko M (1991) Materiały do postglacjalnej historii roślinności okolic Lednicy. Część II. Badania palinologiczne osadów Jeziora Lednickiego - rdzeń I/86 i Wal/87. In: Tobolski K (ed) Wstęp do paleoekologii Lednickiego Parku Krajobrazowego. Poznań: Wydawnictwo Naukowe Uniwersytetu Adama Mickiewicza, Biblioteka Studiów Lednickich 1, pp.63-70.

Makohonienko M (2000) Przyrodnicza historia Gniezna. Bydgoszcz-Poznań: Wydawnictwo Homini.

Marcisz K, Tinner W, Colombaroli D et al. (2015) Long-term hydrological dynamics and fire history over the last 2000 years in CE Europe reconstructed from a high-resolution peat archive. Quaternary Science Reviews 112: 138-152.

Milecka K (1998) Historia działalności człowieka w okolicach Giecza i Wagowa w świetle analizy pyłkowej. Biblioteka Studiów Lednickich 3: 4395.

Milecka K (2005) Historia jezior lobeliowych zachodniej części Borów Tucholskich na tle postglacjalnego rozwoju szaty leśnej. Poznań: Wydawnictwo Naukowe Uniwersytetu Adama Mickiewicza.

Miotk G (1986) Badania palinologiczne osadów z północnego obrzeża Jeziora Godziszewskiego koło Tczewa (Województwo Gdańskie). Badania Fizjograficzne nad Polska Zachodnia. Seria A, Geografia Fizyczna 36: 123-136.

Miotk-Szpiganowicz G (1992) The history of the vegetation of Bory Tucholskie and the role of man in the light of palynological investigations. Acta Palaeobotanica 32: 39-122.

Noryśkiewicz AM (2006) Historia cisa $w$ okolicy Wierzchlasu w świetle analizy pytkowej. Toruń: Instytut Archeologii Uniwersytet Mikołaja Kopernika \& Towarzystwo Przyjaciół Dolnej Wisły.

Noryśkiewicz AM (2013) Historia roślinności i osadnictwa ziemi chetmińskiej w późnym holocenie. Studium palinologiczne. Toruń: Wydawnictwo Naukowe Uniwersytetu Mikołaja Kopernika.

Noryśkiewicz AM (2014) Vegetation and settlement history as reflected by pollen analysis. In: Chudziak W and Kaźmierczak R (eds) The Island in Żótte on Lake Zarańskie. Early Medieval Gateway into West Pomerania. Toruń: Institut of Archaeology, Nicolaus Copernicus University, pp.367-560.

Noryśkiewicz AM (2016) Osadnictwo w północno-zachodniej części strefy chełmińsko-dobrzyńskiej w świetle analizy palinologicznej. In: Chudziak W and Noryśkiewicz AM (eds) Wczesnośredniowieczny zespót osadniczy w Kałdusie. Studia archeologiczno-paleobotaniczne. Toruń: Wydawnictwo Naukowe Uniwersytetu Mikołaja Kopernika, pp.173-193.

Noryśkiewicz B (1982) Lake Steklin a reference site for the Dobrzyń-Chełmno Lake District, northern Poland: Report on palaeoecological studies for the IGCP Project Number 158B. Acta Palaeobotanica 22: 65-83.

Noryśkiewicz B (1987) History of vegetation during the Late-Glacial and Holocene in the Brodnica Lake District in the light of pollen analysis of Lake Strażym deposits. Acta Palaeobotanica 27: 283-304.

Noryśkiewicz B (2004) Vegetation and settlement history in the area of Lake Zawada in the north-eastern part of the Świecie District (northern Poland). Acta Palaeobotanica 44: 195-215. 
Pędziszewska A (2008) Późnoholoceńska historia wybranych fitocenoz leśnych z udziatem grabu (Carpinus betulus L.) i buka (Fagus sylvatica L.) na Pojezierzu Kaszubskim. PhD Thesis, University of Gdańsk, Poland.

Pędziszewska A and Latałowa M (2016) Stand-scale reconstruction of late Holocene forest succession on the Gdańsk Upland (N. Poland) based on integrated palynological and macrofossil data from paired sites. Vegetation History and Archaeobotany 25: $239-254$.

Pędziszewska A, Tylmann W, Witak M et al. (2015) Holocene environmental changes reflected by pollen, diatoms, and geochemistry of annually laminated sediments of Lake Suminko in the Kashubian Lake District (N Poland). Review of Palaeobotany and Palynology $216: 55-75$.

Ralska-Jasiewiczowa M (1966) Bottom sediments of the Mikołajki Lake (Masurian Lake District) in the light of palaeobotanical investigations. Acta Palaeobotanica 7: 3-118.

Ralska-Jasiewiczowa M, Goslar T, Madeyska T et al. (1998) Lake Gościąż central Poland. A monographic study part 1. Kraków: W. Szafer Institute of Botany, Polish Academy of Sciences.

Szal M, Kupryjanowicz M and Wyczółkowski M (2014) Late holocene changes in vegetation of the Mrągowo Lakeland (NE Poland) as registered in the pollen record from Lake Salęt. Studia Quaternaria 31: 51-60.

Święta-Musznicka J and Latałowa M (2016) From wetland to commercial centre: the natural history of Wyspa Spichrzów (“Granary Island”) in medieval Gdańsk, northern Poland. Vegetation History and Archaeobotany 25: 583-599.

Tobolski K (1987) Holocene vegetational development based on the Kluki reference site in the Gardno--eba Plain. Acta Palaeobotanica 27: 179222.

Tobolski K (1991) Dotychczasowy stan badań paleobotanicznych i biostratygraficznych Lednickiego Parku Krajobrazowego. In: Tobolski K (ed) Wstęp do paleoekologii Lednickiego Parku Krajobrazowego. Poznań: Wydawnictwo Naukowe Uniwersytetu Adama Mickiewicza, Biblioteka Studiów Lednickich 1, pp.11-34.

Wacnik A, Ralska-Jasiewiczowa M and Madeyska E (2011) Late Glacial and Holocene history of vegetation in Gostynin area, central Poland. Acta Palaeobotanica 51: 249-278.

Wacnik A, Goslar T and Czernik J (2012) Vegetation changes caused by agricultural societies in the Great Mazurian Lake District. Acta Palaeobotanica 52: 59-104.

Wacnik A, Kupryjanowicz M, Mueller-Bieniek A et al. (2014) The environmental and cultural contexts of the late Iron Age and medieval settlement in the Mazurian Lake District, NE Poland: combined palaeobotanical and archaeological data. Vegetation History and Archaeobotany 23: 439459.

Zimny M (2014) Późnoholoceńska historia roślinności Puszczy Białowieskiej. PhD Thesis, University of Gdańsk, Poland.

Żarczyński M, Wacnik A, Tylmann W (2019) Tracing lake mixing and oxygenation regime using the Fe/Mn ratio in varved sediments: 2000 yearlong record of human-induced changes from Lake Żabińskie (NE Poland). Science of Total Environment 657: 585-596. 
ESM Table S2 Environmental metadata for the sites; site type concerns a period of the Alnus decline event; o- outflow, i- inflow; site numbers as in ESM Table S1 (available online) and Fig. 1.

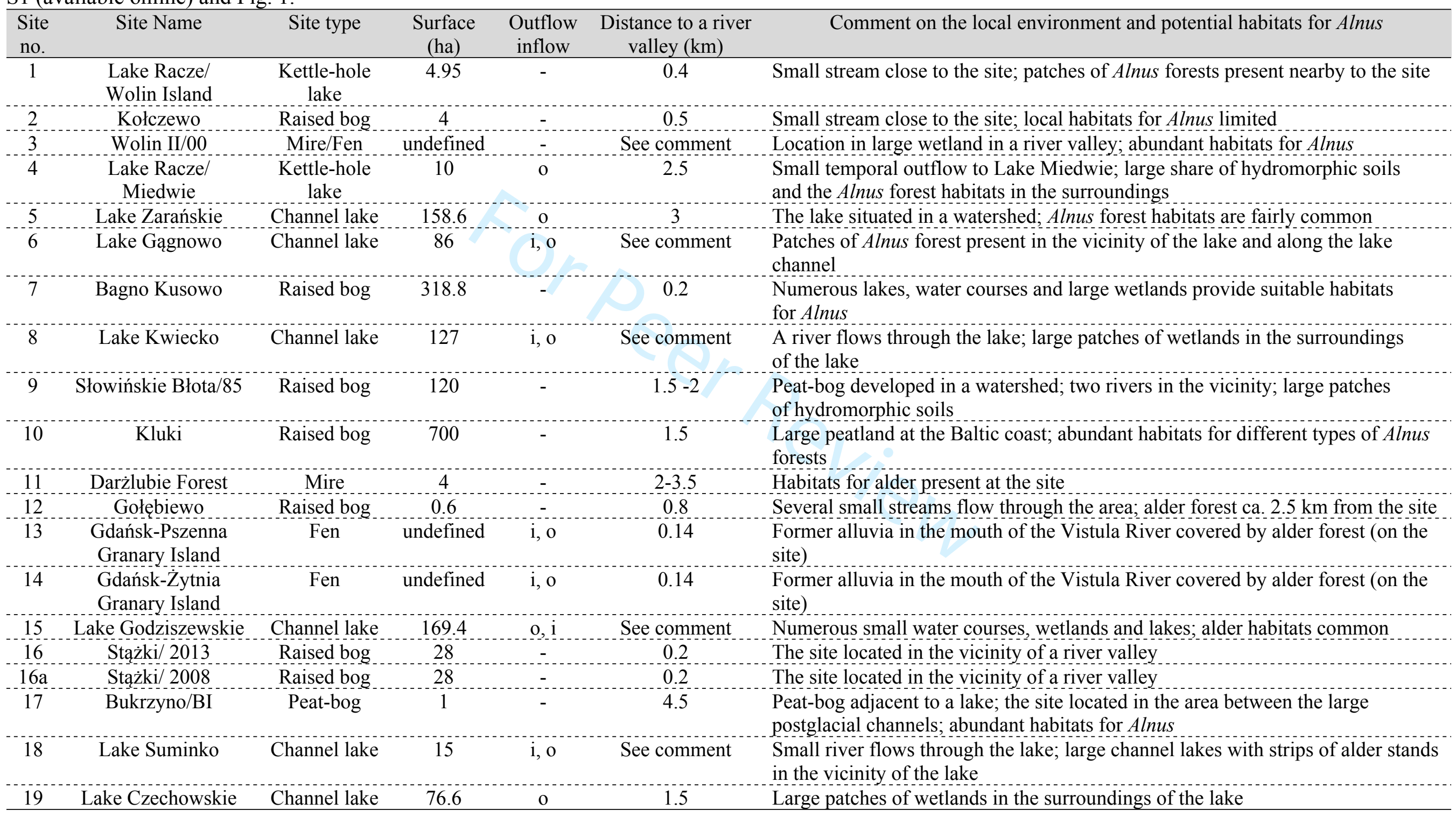




\begin{tabular}{|c|c|c|c|c|c|c|}
\hline $\begin{array}{l}\text { Site } \\
\text { no. }\end{array}$ & Site Name & Site type & $\begin{array}{l}\text { Surface } \\
\text { (ha) }\end{array}$ & $\begin{array}{l}\text { Outflow } \\
\text { inflow }\end{array}$ & $\begin{array}{l}\text { Distance to a river } \\
\text { valley }(\mathrm{km})\end{array}$ & Comment on the local environment and potential habitats for Alnus \\
\hline 20 & Lake Wielkie Gacno & Channel lake & 13.1 & - & $7 ; 4$ & $\begin{array}{l}\text { The lake lies in a long channel lake complex, where patches of hydrogenic soils } \\
\text { are limited; also outside the channel habitats for } A \ln u s \text { are not common }\end{array}$ \\
\hline 21 & Lake Ostrowite & Channel lake & 259 & i, o (?) & 5 & The lake lies in a large channel lake complex \\
\hline 22 & Lake Suszek & Channel lake & 10 & $\mathrm{i}, \mathrm{O}$ & See comment & Dense river net in the surrounding area; hydrogenic soils are common \\
\hline 23 & Tuchola & Peat-bog & 2 & - & 0.4 & $\begin{array}{l}\text { A kettle-hole mire located within an outwash plain; patches of wetlands fairly } \\
\text { common }\end{array}$ \\
\hline 25 & Lake Jelonek & Cave-in lake & 21 & - & 0.3 & $\begin{array}{l}\text { Numerous lakes and patches of wetlands; } 0.3 \mathrm{~km} \text { from a meandering river; } \\
\text { abundant habitats for } A \ln u s\end{array}$ \\
\hline 26 & Zawada & Peat-bog & 20 & - & 8 & $\begin{array}{l}\text { Peat-bog situated close to a large channel lake (35 ha); hydromorphic soils } \\
\text { common }\end{array}$ \\
\hline 27 & Lake Mukrz/I & Channel lake & 43.3 & i, o & See comment & $\begin{array}{l}\text { Small river flows through the lake; large patches of wetlands in the surroundings } \\
\text { of the lake; common habitats for } A \ln u s\end{array}$ \\
\hline 28 & Gruczno & Peat-bog & 2.87 & - & 2.5 & Large alluvial plain of the Vistula River; Alnus forest on the site \\
\hline 30 & Lake Mełno & Channel lake & 162.5 & $\mathrm{i}$ & $2 ; 2.8$ & Numerous lakes and patches of wetlands \\
\hline 31 & Linje/2013 & Raised bog & 5.97 & - & 8 & Large patches of alluvia being habitats for alder forests \\
\hline $31 \mathrm{a}$ & Linje/2016 & Raised bog & 5.97 & - & 8 & Large patches of alluvia being habitats for alder forests \\
\hline 32 & $\begin{array}{l}\text { Lake } \\
\text { Kamionkowskie }\end{array}$ & Channel lake & 63.5 & - & 1.7 & $\begin{array}{l}\text { Dense hydrological net, numerous lakes connected by watercourses and patches } \\
\text { of wetlands; alder carr in the vicinity of the lake }\end{array}$ \\
\hline 33 & Gronowo & Peat-bog & 2.3 & - & $2.7 ; 7.5$ & Peat-bog in a channel; alder carr developed on the site \\
\hline 34 & Lake Strażym & Channel lake & 73.4 & i, o & See comment & $\begin{array}{l}\text { Dense hydrological net, numerous lakes connected by watercourses and patches } \\
\text { of wetlands suitable for alder forests }\end{array}$ \\
\hline 35 & Lake Zwiniarz & Channel lake & 53.7 & o & See comment & $\begin{array}{l}\text { Dense hydrological net including small rivers; common alder forest habitats in } \\
\text { the lake catchment }\end{array}$ \\
\hline 36 & Gązwa & Raised bog & 204 & - & 6.5 & Raised bog with several mineral islands, situated ca. $2.5 \mathrm{~km}$ from a large lake \\
\hline 37 & Lake Salęt & Channel lake & 327.7 & $\mathrm{i}, \mathrm{o}$ & See comment & $\begin{array}{l}\text { The lake lies in the basin of a river; dense hydrological net; common alder forest } \\
\text { habitats in the lake catchment }\end{array}$ \\
\hline 38 & Lake Mikołajki & Channel lake & 424 & i & 6 & $\begin{array}{l}\text { The lake lies in a large channel lake complex; alder carr at the edge of the lake } \\
\text { and in the surrounding area }\end{array}$ \\
\hline
\end{tabular}




\begin{tabular}{|c|c|c|c|c|c|c|}
\hline $\begin{array}{l}\text { Site } \\
\text { no. }\end{array}$ & Site Name & Site type & $\begin{array}{l}\text { Surface } \\
\text { (ha) }\end{array}$ & $\begin{array}{l}\text { Outflow } \\
\text { inflow }\end{array}$ & $\begin{array}{l}\text { Distance to a river } \\
\text { valley }(\mathrm{km})\end{array}$ & Comment on the local environment and potential habitats for Alnus \\
\hline 39 & Lake Wojnowo & Channel lake & 176.3 & $\mathrm{o}, \mathrm{i}$ & See comment & $\begin{array}{l}\text { Several small rivers and watercourses, and a large lake in the vicinity; abundance } \\
\text { of hydrogenic soils }\end{array}$ \\
\hline 40 & Lake Miłkowskie & Channel lake & 23.7 & $0, \mathrm{i}$ & 1.5 & Alder forest habitats are common in the lake catchment \\
\hline 41 & Lake Łazduny & Channel lake & 10.6 & O & 4.5 & Alder forest habitats are common in the lake catchment \\
\hline 42 & Lake Żabińskie & $\begin{array}{l}\text { Kettle-hole } \\
\text { lake }\end{array}$ & 41 & $0, \mathrm{i}$ & 0.4 & $\begin{array}{l}\text { The lake is connected with large Lake Gołdopiwo; it is located in the Wegorapa } \\
\text { River catchment; local habitats for Alnus restricted to the eastern part of the lake } \\
\text { catchment }\end{array}$ \\
\hline 43 & Mechacz Wielki & Raised bog & 146.7 & $\therefore$ & - & The alder carr developed at the edge of the site \\
\hline 44 & Lake Szurpiły & Cave-in lake & 80.9 & $\mathrm{i}, \mathrm{o}$ & 4.5 & $\begin{array}{l}\text { Dense hydrological net in the area; hydromorphic soils close to the lake } \\
\text { and in the river valleys }\end{array}$ \\
\hline 45 & Lake Wigry & Channel lake & 2115 & $\mathrm{i}, \mathrm{o}$ & See comment & $\begin{array}{l}\text { The lake lies in the basin of the Czarna Hańcza River; the river flows through } \\
\text { the lake; abundant habitats for alder forests in the vicinity of the lake }\end{array}$ \\
\hline 46 & Kładkowe Bagno & Raised bog & 40 & - & 2 & Patches of alder forest present close to the site \\
\hline 47 & Maliniak & Raised bog & 0.5 & - & $2 ; 3$ & Dense river net in the area; abundant habitats for alder forests \\
\hline 48 & $\begin{array}{l}\text { BIA/318C, } \\
\text { Białowieża Forest }\end{array}$ & Peat-bog & 0.84 & - & $1 ; 2$ & $\begin{array}{l}\text { Rich hydrological net of rivers and small streams; hydrogenic soils are common; } \\
\text { patches of riparian and alder carr habitats are frequent }\end{array}$ \\
\hline 49 & $\begin{array}{l}\text { BIA/314D, } \\
\text { Białowieża Forest }\end{array}$ & Peat-bog & 1.4 & - & 0.3 & As above \\
\hline 50 & $\begin{array}{c}\text { BIA/340G, } \\
\text { Białowieża Forest }\end{array}$ & Peat-bog & 0.26 & - & 0.65 & As above \\
\hline 51 & $\begin{array}{l}\text { BIA/317C, } \\
\text { Białowieża Forest }\end{array}$ & Peat-bog & 2.04 & - & 1 & As above \\
\hline 52 & $\begin{array}{l}\text { BIA/131C, } \\
\text { Białowieża Forest }\end{array}$ & Peat-bog & 5.5 & - & $1 ; 0.4$ & As above \\
\hline 53 & $\begin{array}{c}\text { BIA/161A, } \\
\text { Białowieża Forest }\end{array}$ & Peat-bog & 2.3 & - & $1.4 ; 0.4$ & As above \\
\hline 54 & Czerlon & Peat-bog & 34 & - & 1.3 & As above \\
\hline 55 & Lake Błedowo & Lake & 8 & O & 0.25 & The lake lies close to a large river valley; hydromorphic soils in a flood plain \\
\hline 56 & Lake Gościąż & Lake & 45.5 & $\mathrm{i}, \mathrm{o}$ & See comment & $\begin{array}{l}\text { The lake lies in the large Vistula River valley and is included to a smaller river } \\
\text { system; wetlands in the river valleys and in the surrounding region are common } \\
\text { and provide abundant habitats for Alnus forests }\end{array}$ \\
\hline
\end{tabular}




\begin{tabular}{|c|c|c|c|c|c|c|}
\hline $\begin{array}{l}\text { Site } \\
\text { no. }\end{array}$ & Site Name & Site type & $\begin{array}{l}\text { Surface } \\
\text { (ha) }\end{array}$ & $\begin{array}{l}\text { Outflow } \\
\text { inflow }\end{array}$ & $\begin{array}{l}\text { Distance to a river } \\
\text { valley }(\mathrm{km})\end{array}$ & Comment on the local environment and potential habitats for Alnus \\
\hline 59 & Lake Gopło & Channel lake & 2154.5 & $\mathrm{i}, \mathrm{o}$ & See comment & $\begin{array}{l}\text { The lake is connected with a large river; hydromorphic soils common } \\
\text { in the surroundings of the lake }\end{array}$ \\
\hline 60 & Lake Kamionek & Channel lake & 3 & $\mathrm{i}, \mathrm{o}$ & 2 & $\begin{array}{l}\text { Dense net of lake channels and patches of wetlands provide habitats for Alnus } \\
\text { forest }\end{array}$ \\
\hline 61 & $\begin{array}{l}\text { Lake } \\
\text { Skrzetuszewskie }\end{array}$ & Lake & ca. 2.5 & $\mathrm{i}, \mathrm{o}$ & See comment & $\begin{array}{l}\text { The lake lies immediately to the large Lake Lednica; small river flows through } \\
\text { the lake; local habitats for Alnus restricted to the surroundings of lakes }\end{array}$ \\
\hline 62 & Lake Lednica I/86 & Channel lake & 348 & $\mathrm{i}, \mathrm{o}$ & See comment & $\begin{array}{l}\text { Small rivers flow through the lake; large patches of hydrogenic soils suitable for } \\
\text { Alnus along the lake }\end{array}$ \\
\hline 63 & Lake Głeboczek & Channel lake & 12.5 & o & 0.24 & Dense net of lake channels and small rivers provides habitats for $A$ lnus \\
\hline 64 & Lake Swiętokrzyskie & Channel lake & 14 & $\mathrm{i}, \mathrm{o}$ & See comment & Dense net of lake channels and small rivers provides habitats for Alnus \\
\hline 65 & Lake Baba & Channel lake & 2.7 & $\mathrm{i}, \mathrm{o}$ & 2.3 & Alnus forest habitats restricted to lake channels \\
\hline 66 & Giecz 4/90 & Peat-bog & 3 & - & 0.5 & $\begin{array}{l}\text { The core taken from an archaeological trench located at the former } \\
\text { bridge/causeway crossing wetland; a river in the vicinity of the site }\end{array}$ \\
\hline 67 & Lake Wonieść & Channel lake & 121 & $\mathrm{i}, \mathrm{o}$ & 4.3 & $\begin{array}{l}\text { The lake connected with other } 5 \text { other lakes, situated between two rivers; } \\
\text { habitats for } A \ln u s \text { are common }\end{array}$ \\
\hline 68 & $\begin{array}{l}\text { Lake Paklicko } \\
\text { Wielkie }\end{array}$ & Channel lake & 196 & $\mathrm{i}, \mathrm{o}$ & See comment & $\begin{array}{l}\text { The lake is included to a river system; dense hydrological net and patches of } \\
\text { wetlands; potential habitats for Alnus forest are common }\end{array}$ \\
\hline 69 & Lake Długie & Channel lake & 95.5 & $\mathrm{i}, \mathrm{o}$ & 2 & $\begin{array}{l}\text { Dense hydrological net and patches of wetlands along a meandering river; } \\
\text { potential habitats for Alnus forest are common }\end{array}$ \\
\hline
\end{tabular}


ESM Table S3 Palaeoecological characteristics around the Alnus decline; HI - human impact: $\mathrm{h}$ - high, $\mathrm{m}$ - moderate, 1 - low, a - absent; NPPs - nonpollen palynomorphs; site numbers as in ESM Table S1(available online) and Fig. 1; for references, see Table S1.

\begin{tabular}{|c|c|c|c|c|c|c|}
\hline $\begin{array}{l}\text { Site } \\
\text { No. }\end{array}$ & Site Name & $\begin{array}{l}\text { Concurrent decline } \\
\text { in tree taxa }\end{array}$ & $\begin{array}{l}\text { Concurrent rise } \\
\text { in tree taxa }\end{array}$ & $\mathrm{HI}$ & $\begin{array}{l}\text { Changes in sediments and occurrence of local } \\
\text { ecosystem taxa (aquatic and mire organisms) }\end{array}$ & $\begin{array}{l}\text { Comment on environmental changes concurrent } \\
\text { with the Alnus decline }\end{array}$ \\
\hline 1 & $\begin{array}{l}\text { Lake Racze/ } \\
\text { Wolin Island }\end{array}$ & Fagus & $\begin{array}{l}\text { Pinus, Betula, } \\
\text { Salix, Quercus }\end{array}$ & $\mathrm{h}$ & $\begin{array}{l}\text { Sediment change: increase of mineral matter; } \\
\text { Pediastrum rises }\end{array}$ & $\begin{array}{l}\text { The decline was concurrent with an intensive } \\
\text { human impact phase; increase of denudation } \\
\text { processes and trophy of the lake }\end{array}$ \\
\hline 2 & Kołczewo & Fagus, Carpinus & Pinus, Salix & 1 & $\begin{array}{l}\text { Calluna expansion and abundant Sphagnum } \\
\text { spores }\end{array}$ & $\begin{array}{l}\text { Start of the decline at the beginning of a human } \\
\text { impact phase; drier condition during the event }\end{array}$ \\
\hline 3 & Wolin II $/ 00$ & $\begin{array}{l}\text { Ulmus, Corylus, } \\
\text { Quercus }\end{array}$ & $\begin{array}{l}\text { Salix, Sambucus } \\
\text { nigra }\end{array}$ & $\mathrm{h}$ & $\begin{array}{l}\text { Laxe decline; large peak of HdV-200; rise } \\
\text { of Phragmites-t. pollen and macrofossils } \\
\text { of Ranunculus sceleratus, Juncus spp. } \\
\text { and Eleocharis spp. }\end{array}$ & $\begin{array}{l}\text { The decline happened during strong human } \\
\text { impact phase accompanied by fire indicators; } \\
\text { distinct decline in the water table }\end{array}$ \\
\hline 4 & $\begin{array}{l}\text { Lake Racze/ } \\
\text { Miedwie }\end{array}$ & - & $\begin{array}{l}\text { Pinus, Betula, } \\
\text { Salix, Populus, } \\
\text { Quercus }\end{array}$ & $\mathrm{h}$ & $\begin{array}{l}\text { Lithological limit: an increase of organic matter } \\
\text { and fraction of sand in mineral matter total; } \\
\text { important trophic changes reflected by NPPs }\end{array}$ & $\begin{array}{l}\text { Alnus declined after the Carpinus and Fagus } \\
\text { declines, during an intensive human impact phase; } \\
\text { increase of denudation processes and trophy } \\
\text { of the lake }\end{array}$ \\
\hline 5 & Lake Zarańskie & Fraxinus & $\begin{array}{l}\text { Salix, Betula, } \\
\text { Pinus Quercus }\end{array}$ & $\mathrm{h}$ & Pediastrum rises & $\begin{array}{l}\text { Alnus declined after the Carpinus and Fagus } \\
\text { declines, during an intensive human impact phase; } \\
\text { trophy of the lake increased }\end{array}$ \\
\hline 6 & Lake Gągnowo & & Quercus, Betula & $\mathrm{h}$ & Pediastrum strongly rises & $\begin{array}{l}\text { Alnus declined after the Carpinus and Fagus } \\
\text { declines, during an intensive human impact phase; } \\
\text { trophy of the lake increased }\end{array}$ \\
\hline 7 & Bagno Kusowo & - & Pinus, Quercus & $\mathrm{m}$ & $\begin{array}{l}\text { Ca. AD } 850 \text { short wet shift, recorded on the basis } \\
\text { of macrofossils and testate amoeba; } \\
\text { gap in Eriophorum vaginatum, peak of Arcella } \\
\text { discoides }\end{array}$ & $\begin{array}{l}\text { Alnus declined after the Carpinus and Fagus } \\
\text { declines, during a human impact phase; } \\
\text { hydrological instability at the event }\end{array}$ \\
\hline 8 & Lake Kwiecko & - & Pinus, Betula & 1 & $\begin{array}{l}\text { Increase of corroded pollen and charcoal } \\
\text { in the sediments }\end{array}$ & $\begin{array}{l}\text { Alnus declined slightly before the Carpinus } \\
\text { and Fagus declines, and slightly before the } \\
\text { beginning of a moderate human impact phase }\end{array}$ \\
\hline 9 & $\begin{array}{l}\text { Słowińskie } \\
\text { Błota/85 }\end{array}$ & - & Pinus, Fagus & 1 & $\begin{array}{l}\text { Lithological limit (E.vaginatum layer); rise of } \\
\text { Sphagnum, peak and then decline of Assulina, } \\
\text { Archerella and Arcella }\end{array}$ & $\begin{array}{l}\text { Alnus declined after the Carpinus decline } \\
\text { at a minute human impact phase; hydrological } \\
\text { disturbances: dry-wet-dry shifts }\end{array}$ \\
\hline
\end{tabular}




\begin{tabular}{|c|c|c|c|c|c|c|}
\hline $\begin{array}{l}\text { Site } \\
\text { No. }\end{array}$ & Site Name & $\begin{array}{l}\text { Concurrent decline } \\
\text { in tree taxa }\end{array}$ & $\begin{array}{l}\text { Concurrent rise } \\
\text { in tree taxa }\end{array}$ & $\mathrm{HI}$ & $\begin{array}{l}\text { Changes in sediments and occurrence of local } \\
\text { ecosystem taxa (aquatic and mire organisms) }\end{array}$ & $\begin{array}{l}\text { Comment on environmental changes concurrent } \\
\text { with the Alnus decline }\end{array}$ \\
\hline 10 & Kluki & Carpinus & Betula, Fagus & 1 & $\begin{array}{l}\text { Peak of Cladium mariscus and appearances } \\
\text { of Utricularia, Ceratophyllum and Pediastrum } \\
\text { immediately below the Alnus decline; distinct } \\
\text { decline of Cyperaceae, rise of Calluna and } \\
\text { Ericaceae, and gradual rise of Sphagnum } \\
\text { at the event level }\end{array}$ & $\begin{array}{l}\text { Low intensity human impact phase; wet-dry } \\
\text { hydrological shifts at the beginning of the Alnus } \\
\text { decline }\end{array}$ \\
\hline 11 & $\begin{array}{l}\text { Daržlubie } \\
\text { Forest }\end{array}$ & Quercus, Carpinus & $\begin{array}{l}\text { Betula, Pinus, } \\
\text { Salix, Fagus }\end{array}$ & 1 & $\begin{array}{l}\text { No distinct changes in the sediment; } \\
\text { macrocharcoal present }\end{array}$ & $\begin{array}{l}\text { The Alnus decline was concurrent with } \\
\text { the beginning of a human impact phase }\end{array}$ \\
\hline 12 & Gołębiewo/GI & Quercus & $\begin{array}{l}\text { Populus, } \\
\text { Quercus, Fagus }\end{array}$ & 1 & $\begin{array}{l}\text { Filicales rise (small), ombrotrophic taxa still } \\
\text { and Archerella flavum decrease and then } \\
\text { reappear }\end{array}$ & $\begin{array}{l}\text { Alnus declined before the Carpinus decline, } \\
\text { at the beginning of a human impact phase; } \\
\text { wet event ca. AD 950-1080 interrupted a dry } \\
\text { phase (ca. AD 670-1320) }\end{array}$ \\
\hline 13 & $\begin{array}{l}\text { Gdańsk- } \\
\text { Pszenna } \\
\text { Granary Island }\end{array}$ & $\begin{array}{l}\text { Fraxinus, } \\
\text { Quercus, Carpinus }\end{array}$ & Pinus & 1 & $\begin{array}{l}\text { Distinct sediment change; local alder groves } \\
\text { and oxbows with aquatics replaced by open-fen } \\
\text { vegetation with Cyperaceae and Filicales; high } \\
\text { frequency of fungi developing on decaying wood }\end{array}$ & $\begin{array}{l}\text { Human activity evidence negligible; distinct drop } \\
\text { in the ground water table }\end{array}$ \\
\hline 14 & $\begin{array}{l}\text { Gdańsk-Żytnia } \\
\text { Granary Island }\end{array}$ & Carpinus, Fagus & Pinus & 1 & $\begin{array}{l}\text { Distinct sediment change; local alder groves } \\
\text { and oxbows with aquatics replaced by open-fen } \\
\text { vegetation with Cyperaceae, Filicales; high } \\
\text { frequency of fungi developing on decaying wood }\end{array}$ & $\begin{array}{l}\text { Human activity evidence negligible; distinct drop } \\
\text { in the ground water table }\end{array}$ \\
\hline 15 & $\begin{array}{l}\text { Lake } \\
\text { Godziszewskie }\end{array}$ & Betula, Carpinus & Pinus & 1 & $\begin{array}{l}\text { Distinct lithological limit between algae gyttia } \\
\text { and coarse detritus gyttia; rise of corroded pollen } \\
\text { in the sediments; Filicales monolete spores } \\
\text { decline, pollen of Cyperaceae strongly rises }\end{array}$ & $\begin{array}{l}\text { The Alnus decline concurrent with the beginning } \\
\text { of a new human impact phase; hydrological } \\
\text { disturbances immediately before the } \text { Alnus fall }\end{array}$ \\
\hline 16 & Stążki/2013 & - & Betula, Fagus & 1 & $\begin{array}{l}\text { Sphagnum sect. Acutifolia and A. flavum } \\
\text { dominate; small peak of Sph. Cuspidatum } \\
\text { at around AD } 1000\end{array}$ & $\begin{array}{l}\text { Alnus declined after the Carpinus decline; weak } \\
\text { human impact evidence; short dry shift at around } \\
\text { the } 9^{\text {th }} \text { c., wet event at around AD } 1000 \text {, and then } \\
\text { dry shift around AD } 1140\end{array}$ \\
\hline $16 a$ & Stążki/2008 & - & Pinus, Betula & 1 & $\begin{array}{l}\text { Decline of } A \text {. flavum, increase of Assulina } \\
\text { muscorum and A. seminulum }\end{array}$ & $\begin{array}{l}\text { Alnus declined after the Carpinus decline; weak } \\
\text { human impact; wet before the event, decrease } \\
\text { of the water table at the alder decline and then } \\
\text { wet and dry shifts before AD 1000; strong wet } \\
\text { shift c. AD } 1100\end{array}$ \\
\hline
\end{tabular}




\begin{tabular}{|c|c|c|c|c|c|c|}
\hline $\begin{array}{l}\text { Site } \\
\text { No. }\end{array}$ & Site Name & $\begin{array}{l}\text { Concurrent decline } \\
\text { in tree taxa }\end{array}$ & $\begin{array}{l}\text { Concurrent rise } \\
\text { in tree taxa }\end{array}$ & $\mathrm{HI}$ & $\begin{array}{l}\text { Changes in sediments and occurrence of local } \\
\text { ecosystem taxa (aquatic and mire organisms) }\end{array}$ & $\begin{array}{c}\text { Comment on environmental changes concurrent } \\
\text { with the Alnus decline }\end{array}$ \\
\hline 17 & Bukrzyno & Carpinus, Tilia & $\begin{array}{l}\text { Betula, Salix, } \\
\text { Fagus }\end{array}$ & $\mathrm{m}$ & $\begin{array}{l}\text { Peak of Sphagnum and E. vaginatum is present; } \\
\text { Daphnia decreases; Assulina spp. and A. flavum } \\
\text { rise at the recovery of Alnus }\end{array}$ & $\begin{array}{l}\text { Alnus declined during moderate human impact } \\
\text { phase accompanied by fire indicators; wet before } \\
\text { the event, drier condition during the event }\end{array}$ \\
\hline 18 & Lake Suminko & Carpinus & $\begin{array}{l}\text { Ulmus, Fagus, } \\
\text { Betula, Salix }\end{array}$ & 1 & $\begin{array}{l}\text { Minute changes in lithology (lamination, color); } \\
\text { small increase of Filicales spores and rise } \\
\text { of Anabaena and Tetraedron minimum }\end{array}$ & $\begin{array}{l}\text { Alnus declined after the Carpinus decline } \\
\text { at a minute human impact phase; changing trophy } \\
\text { of the lake }\end{array}$ \\
\hline 19 & $\begin{array}{l}\text { Lake } \\
\text { Czechowskie }\end{array}$ & $\begin{array}{l}\text { No distinct } \\
\text { changes in tree } \\
\text { taxa }\end{array}$ & Betula, Salix & 1 & $\begin{array}{l}\text { do macroscopic changes in lithology; rapid } \\
\text { decrease of Tetraedron, small rise of Cyperaceae } \\
\text { and Filicales }\end{array}$ & $\begin{array}{l}\text { Alnus declined in the condition of a very weak } \\
\text { (negligible) human activity }\end{array}$ \\
\hline 20 & $\begin{array}{l}\text { Lake Wielkie } \\
\text { Gacno }\end{array}$ & - & - & - & - & The event weakly expressed; unclear \\
\hline 21 & Lake Ostrowite & - & - & & - & The event weakly expressed; unclear \\
\hline 22 & Lake Suszek & $\begin{array}{l}\text { Carpinus, } \\
\text { Fraxinus }\end{array}$ & $\begin{array}{l}\text { Pinus, Betula, } \\
\text { Populus, Salix }\end{array}$ & 1 & $\begin{array}{l}\text { Lithological limit: algal gyttja changes onto } \\
\text { coarse detritus gyttja; Pediastrum declines, } \\
\text { Filicales, Phragmites-t. and Cyperaceae rise }\end{array}$ & $\begin{array}{l}\text { Alnus decline was concurrent with the beginning } \\
\text { of a human impact phase; lowering of the lake } \\
\text { water table }\end{array}$ \\
\hline 23 & Tuchola & - & Betula & 1 & $\begin{array}{l}\text { Significant decline of Cyperaceae, peak } \\
\text { of Sphagnum }\end{array}$ & $\begin{array}{l}\text { Alnus declined after the Carpinus decline; } \\
\text { low intensity human impact phase; dry period }\end{array}$ \\
\hline 24 & Lake Kęsowo & Carpinus & $\begin{array}{l}\text { Salix, Populus, } \\
\text { Pinus }\end{array}$ & 1 & Unclear & $\begin{array}{l}\text { The Alnus decline was concurrent with the } \\
\text { beginning of a human impact phase }\end{array}$ \\
\hline 25 & Lake Jelonek & $\begin{array}{l}\text { Carpinus } \\
\text { fluctuates }\end{array}$ & Pinus, Betula & 1 & $\begin{array}{l}\text { Decrease of Pediastrum and pelagial diatoms, } \\
\text { rise of epiphytic and benthic diatoms }\end{array}$ & $\begin{array}{l}\text { Alnus declined after the Carpinus decline; } \\
\text { low human impact phase; lowering of the lake } \\
\text { water table }\end{array}$ \\
\hline 26 & Zawada & No data & Pinus & 1 & Hiatus below the event - low water level & Lowering of the lake water table \\
\hline 27 & Lake Mukrz I & $\begin{array}{l}\text { Small decline of } \\
\text { Carpinus }\end{array}$ & Betula & 1 & Change not recorded & $\begin{array}{l}\text { Alnus declined before the main decline of } \\
\text { Carpinus at a minute, initial human impact phase }\end{array}$ \\
\hline 28 & Gruczno & - & Betula, Pinus & $\mathrm{m}$ & $\begin{array}{l}\text { Decline of Ericaceae and Cyperaceae, rise } \\
\text { of Sphagnum and Amphitrema }\end{array}$ & $\begin{array}{l}\text { Alnus declined after the Carpinus and Quercus } \\
\text { decline, during a human impact phase; drop of the } \\
\text { ground water level on the bog }\end{array}$ \\
\hline 29 & Lake Czyste & - & $\begin{array}{l}\text { Pinus, Betula, } \\
\text { Corylus }\end{array}$ & 1 & $\begin{array}{l}\text { Change in the lithology: the proportions } \\
\text { of mineral matter increase; small increase } \\
\text { of Pediastrum }\end{array}$ & $\begin{array}{l}\text { Alnus declined after the Carpinus decline } \\
\text { at the beginning of a human impact phase; } \\
\text { higher lake trophy }\end{array}$ \\
\hline
\end{tabular}




\begin{tabular}{|c|c|c|c|c|c|c|}
\hline $\begin{array}{l}\text { Site } \\
\text { No. }\end{array}$ & Site Name & $\begin{array}{l}\text { Concurrent decline } \\
\text { in tree taxa }\end{array}$ & $\begin{array}{l}\text { Concurrent rise } \\
\text { in tree taxa }\end{array}$ & HI & $\begin{array}{l}\text { Changes in sediments and occurrence of local } \\
\text { ecosystem taxa (aquatic and mire organisms) }\end{array}$ & $\begin{array}{c}\text { Comment on environmental changes concurrent } \\
\text { with the Alnus decline }\end{array}$ \\
\hline 30 & Lake Mełno & Fraxinus, Ulmus & $\begin{array}{l}\text { Betula, Salix, } \\
\text { Quercus }\end{array}$ & $\mathrm{m}$ & $\begin{array}{l}\text { Lithology change not recorded; increase } \\
\text { of Pediastrum, small peak of Cyperaceae }\end{array}$ & $\begin{array}{l}\text { The Alnus decline was preceded by the decline } \\
\text { of Carpinus and development of a settlement } \\
\text { phase; higher lake trophy }\end{array}$ \\
\hline 31 & Linje/2013 & Quercus, Carpinus & Pinus, Betula & $\mathrm{m}$ & $\begin{array}{l}\text { Decrease of Assulina, Amphitrema and Callidina } \\
\text { angusticollis; increase of Calluna, Ericaceae, } \\
\text { Ledum, Sphagnum and Entophlictis lobata; }\end{array}$ & $\begin{array}{l}\text { The Alnus decline was concurrent with } \\
\text { the beginning of a human impact phase; } \\
\text { decrease of the water table }\end{array}$ \\
\hline $31 \mathrm{a}$ & Linje/2016 & $\begin{array}{l}\text { Ulmus, Fraxinus, } \\
\text { Carpinus }\end{array}$ & Betula, Salix & $\mathrm{m}$ & $\begin{array}{l}\text { A. flavum declines, Amphitrema wrightianum } \\
\text { increases together with Centropyxis aculeata and } \\
\text { Difflugia globulosa; Sphagnum declines (spores } \\
\text { and macrofos dominated by Sph. magellanicum), } \\
\text { while proportions of Carex radicelle strongly } \\
\text { increase; Scheuchzeria palustris up to } 20 \% \text { of } \\
\text { macrofossils at the limit between the phases }\end{array}$ & $\begin{array}{l}\text { The Alnus decline was concurrent with the } \\
\text { beginning of a human impact phase accompanied } \\
\text { with fire indicators; change in the bog wetness } \\
\text { just at the alder decline from moderately wet to } \\
\text { wet; a short hiatus in-between? }\end{array}$ \\
\hline 32 & $\begin{array}{l}\text { Lake } \\
\text { Kamionkowskie }\end{array}$ & Pinus, Fraxinus & Betula, Salix & 1 & Pediastrum rises & $\begin{array}{l}\text { Alnus declined after the Carpinus decline } \\
\text { at the beginning of a low human impact phase; } \\
\text { higher lake trophy }\end{array}$ \\
\hline 33 & Gronowo & Ulmus & $\begin{array}{l}\text { Pinus, Salix, } \\
\text { Betula }\end{array}$ & $\mathrm{m}$ & $\begin{array}{l}\text { Increase of Calluna and Sphagnum; Assulina, } \\
\text { C. angusticollis Amphitrema and Entophlictis } \\
\text { lobata fluctuate }\end{array}$ & $\begin{array}{l}\text { Alnus declined after the Carpinus decline } \\
\text { and after the start of a human impact phase; } \\
\text { wet and dry shifts }\end{array}$ \\
\hline 34 & Lake Strażym & - & Pinus, Betula & 1 & Pediastrum peaks and then declines & $\begin{array}{l}\text { Alnus declined after the Carpinus decline } \\
\text { at a minute human impact phase; lowering } \\
\text { of the lake water table (?) }\end{array}$ \\
\hline 35 & Lake Zwiniarz & Carpinus & Betula & 1 & Not recorded & $\begin{array}{l}\text { The Alnus decline was concurrent } \\
\text { with the beginning of a human impact phase }\end{array}$ \\
\hline 36 & Gązwa & Picea & Betula & 1 & $\begin{array}{l}\text { Ca. AD } 600 \text { - AD } 950 \text { Sph. fuscum/rubellum } \\
\text { replaced by Sph. cuspidatum; A. wrightianum } \\
\text { rises, A.flavum declines; peak of E. vaginatum }\end{array}$ & $\begin{array}{l}\text { Alnus decline took place at a minute human } \\
\text { impact phase; low resolution data for the event } \\
\text { (a hiatus?); high water level before the event, then } \\
\text { rapid drop at the Alnus decline and again higher } \\
\text { water level at the alder recovery }\end{array}$ \\
\hline 37 & Lake Salęt & Betula, Salix & Picea & $\mathrm{a} / \mathrm{l}^{-}$ & No data & $\begin{array}{l}\text { The Alnus decline contemporary with the decline } \\
\text { of settlement indicators }\end{array}$ \\
\hline 38 & Lake Mikołajki & & - & & & The event weakly expressed; unclear \\
\hline
\end{tabular}




\begin{tabular}{|c|c|c|c|c|c|c|}
\hline $\begin{array}{l}\text { Site } \\
\text { No. }\end{array}$ & Site Name & $\begin{array}{l}\text { Concurrent decline } \\
\text { in tree taxa }\end{array}$ & $\begin{array}{l}\text { Concurrent rise } \\
\text { in tree taxa }\end{array}$ & $\mathrm{HI}$ & $\begin{array}{l}\text { Changes in sediments and occurrence of local } \\
\text { ecosystem taxa (aquatic and mire organisms) }\end{array}$ & $\begin{array}{l}\text { Comment on environmental changes concurrent } \\
\text { with the Alnus decline }\end{array}$ \\
\hline 39 & Lake Wojnowo & Populus, Salix & $\begin{array}{l}\text { Betula, Corylus, } \\
\text { Fraxinus }\end{array}$ & $\mathrm{m}$ & Increase of Cyperaceae & $\begin{array}{l}\text { The Alnus decline dated to the } 5^{\text {th }} \text { century, } \\
\text { concurrent with a distinct human impact phase }\end{array}$ \\
\hline 40 & $\begin{array}{l}\text { Lake } \\
\text { Miłkowskie }\end{array}$ & - & -1 & - & - & $\begin{array}{l}\text { The event unclear due to the low resolution pollen } \\
\text { data? }\end{array}$ \\
\hline 41 & Lake Lazduny & Carpinus, Quercus & Betula, Pinus & 1 & $\begin{array}{l}\text { Decline of Tetraedron and Botryococcus; } \\
\text { peaks of Cyperaceae, Filicales and Phragmites-t. }\end{array}$ & $\begin{array}{l}\text { Low resolution data; decline of the lake water } \\
\text { table }\end{array}$ \\
\hline 42 & Lake Żabińskie & Carpinus & Pinus, Quercus & 1 & No data & $\begin{array}{l}\text { The event concurrent with a low human impact } \\
\text { phase }\end{array}$ \\
\hline 43 & $\begin{array}{l}\text { Mechacz } \\
\text { Wielki } \\
(\text { MW/I })\end{array}$ & $\begin{array}{l}\text { Picea rises and } \\
\text { then falls }\end{array}$ & Betula, Pinus & 1 & $\begin{array}{l}\text { Short peak of Sph. cuspidatum within a Sph. } \\
\text { rubellum/fuscum phase }\end{array}$ & $\begin{array}{l}\text { Indicators of human activity absent; ca. AD } 800 \\
\text { decrease of water level and up to AD } 1050 \text { stable } \\
\text { hydrological conditions; short wet event at the } \\
\text { Alnus decline (MWII); wet phase at the alder } \\
\text { regeneration ca. AD } 1050 \text { (Oort Minimum) }\end{array}$ \\
\hline 44 & Lake Szurpiły & $\begin{array}{l}\text { Carpinus, } \\
\text { Fraxinus }\end{array}$ & $\begin{array}{c}\text { Betula, } \\
\text { Populus, Salix }\end{array}$ & 1 & No data & Scattered pollen of anthropogenic indicators \\
\hline 45 & Lake Wigry & - & - & - & & The decline difficult to date \\
\hline 46 & $\begin{array}{l}\text { Kładkowe } \\
\text { Bagno }\end{array}$ & - & - & - & No data & Several Alnus pollen curve fluctuations \\
\hline 47 & Maliniak & $\begin{array}{l}\text { Fluctuation of } \\
\text { most of the tree } \\
\text { taxa }\end{array}$ & $\begin{array}{l}\text { Pinus, } \\
\text { Betula }\end{array}$ & 1 & No data & $\begin{array}{l}\text { The decline weakly expressed; low human impact } \\
\text { phase }\end{array}$ \\
\hline 48 & $\begin{array}{l}\text { BIA/318C, } \\
\text { Białowieża } \\
\text { Forest }\end{array}$ & $\begin{array}{l}\text { Fluctuation of } \\
\text { most of the tree } \\
\text { taxa }\end{array}$ & Pinus & $\mathrm{a}$ & $\begin{array}{l}\text { Decrease of Calluna and Cyperaceae; gap } \\
\text { in Botryococcus and Carex elata (macros); } \\
\text { peaks of Sphagnum and Tilletia sphagni }\end{array}$ & $\begin{array}{l}\text { Indicators of settlement absent and strong decline } \\
\text { of fire proxies; water table lowering on the peat- } \\
\text { bog }\end{array}$ \\
\hline 49 & $\begin{array}{l}\text { BIA/314D, } \\
\text { Białowieża } \\
\text { Forest }\end{array}$ & $\begin{array}{l}\text { Fluctuation of } \\
\text { most of the tree } \\
\text { taxa }\end{array}$ & $\begin{array}{l}\text { Pinus, Picea, } \\
\text { Salix, Tilia }\end{array}$ & $\mathrm{a}$ & $\begin{array}{l}\text { Decrease of E. vaginatum, Andromeda polifolia, } \\
\text { Ledum, Cyperaceae, Entophlictis lobata and } \\
\text { Botryococcus; significant increase of Sphagnum } \\
\text { and T. sphagni; abundant microcharcoal }\end{array}$ & $\begin{array}{l}\text { Indicators of settlement almost absent, but those } \\
\text { of fires present; water table lowering on the bog }\end{array}$ \\
\hline 50 & $\begin{array}{l}\text { BIA/340G, } \\
\text { Białowieża } \\
\text { Forest }\end{array}$ & $\begin{array}{l}\text { Fluctuation of } \\
\text { most of the tree } \\
\text { taxa }\end{array}$ & Pinus & 1 & $\begin{array}{l}\text { Decrease of Sphagnum, T. sphagni and } \\
\text { E. vaginatum; increase of Calluna, Cyperaceae } \\
\text { and Filicales }\end{array}$ & $\begin{array}{l}\text { Beginning of a weak settlement; hydrological } \\
\text { disturbances on the bog }\end{array}$ \\
\hline
\end{tabular}




\begin{tabular}{|c|c|c|c|c|c|c|}
\hline $\begin{array}{l}\text { Site } \\
\text { No. }\end{array}$ & Site Name & $\begin{array}{l}\text { Concurrent decline } \\
\text { in tree taxa }\end{array}$ & $\begin{array}{l}\text { Concurrent rise } \\
\text { in tree taxa }\end{array}$ & $\mathrm{HI}$ & $\begin{array}{l}\text { Changes in sediments and occurrence of local } \\
\text { ecosystem taxa (aquatic and mire organisms) }\end{array}$ & $\begin{array}{c}\text { Comment on environmental changes concurrent } \\
\text { with the Alnus decline }\end{array}$ \\
\hline 51 & $\begin{array}{l}\text { BIA } / 317 \mathrm{C} \\
\text { Białowieża } \\
\text { Forest }\end{array}$ & $\begin{array}{l}\text { Salix, Fraxinus, } \\
\text { Corylus }\end{array}$ & $\begin{array}{l}\text { Pinus, Betula, } \\
\text { Picea }\end{array}$ & $\mathrm{a}$ & $\begin{array}{l}\text { Disappearance of green algae (Botryococcus, } \\
\text { Spirogyra, Zygnema, Mougeotia); peak of } \\
\text { Sphagnum and T. sphagni }\end{array}$ & $\begin{array}{l}\text { Indicators of settlement absent; decrease } \\
\text { of the water level on the bog }\end{array}$ \\
\hline 52 & $\begin{array}{l}\text { BIA } / 131 \mathrm{C}, \\
\text { Białowieża } \\
\text { Forest }\end{array}$ & $\begin{array}{l}\text { Ulmus, Fraxinus, } \\
\text { Salix }\end{array}$ & Picea & $\mathrm{a}$ & $\begin{array}{l}\text { Increase of Calluna, peak of Sphagnum, } \\
\text { important rise of } E \text {. lobata }\end{array}$ & $\begin{array}{l}\text { Indicators of settlement almost absent; } \\
\text { hydrological disturbances on the bog }\end{array}$ \\
\hline 53 & $\begin{array}{l}\text { BIA/161A, } \\
\text { Białowieża } \\
\text { Forest }\end{array}$ & - & - & $\mathrm{a}$ & - & $\begin{array}{l}\text { The Alnus difficult to identify; hydrological } \\
\text { disturbances on the bog; human activity negligible }\end{array}$ \\
\hline 54 & Czerlon & Betula & $\begin{array}{l}\text { Pinus, Salix, } \\
\text { Picea, Quercus, } \\
\text { Carpinus }\end{array}$ & $\mathrm{a}$ & $\begin{array}{l}\text { Decline of the mire indicators (Cyperaceae), } \\
\text { expansion of the raised-bog taxa: important rise } \\
\text { of Sphagnum, small peaks of } A \text {. wrightianum, } \\
\text { A. flavum, Assulina, Heleopera, Hyalosphenia } \\
\text { papillo; rise of E. lobata at the end of the phase }\end{array}$ & $\begin{array}{l}\text { Indicators of settlement almost absent, indicators } \\
\text { of fires decline; wet conditions before the alder } \\
\text { decline, then dry and wet shifts; } \\
\text { ombrotrophication of the bog }\end{array}$ \\
\hline 55 & Lake Błędowo & $\begin{array}{l}\text { Carpinus, } \\
\text { Quercus, Fraxinus }\end{array}$ & $\begin{array}{l}\text { Betula, } \\
\text { Populus, Salix }\end{array}$ & 1 & $\begin{array}{l}\text { Increase of diversity and considerable fluctuation } \\
\text { of the planktonic diatoms }\end{array}$ & $\begin{array}{l}\text { The event concurrent with an early human impact } \\
\text { phase; before and during the Alnus decline higher } \\
\text { water level }\end{array}$ \\
\hline 56 & Lake Gościąż & Carpinus & $\begin{array}{l}\text { Pinus, Salix, } \\
\text { Ulmus, } \\
\text { Fraxinus }\end{array}$ & 1 & $\begin{array}{l}\text { Small increase of Cyperaceae and then } \\
\text { expansion of the pelagial Cladocera; decline } \\
\text { of the pollen influx }\end{array}$ & $\begin{array}{l}\text { The low resolution sampling in the section under } \\
\text { concern restricts the interpretation; the Alnus } \\
\text { decline seems to be concurrent with the beginning } \\
\text { of an anthropogenic phase; lower water table } \\
\text { before the event; after AD } 1000 \text { distinct rise of the } \\
\text { water table }\end{array}$ \\
\hline 57 & Lake Białe & Carpinus & Pinus, Betula & 1 & Poor data & $\begin{array}{l}\text { The Alnus decline was concurrent with the } \\
\text { beginning of a human impact phase }\end{array}$ \\
\hline 58 & Lake Steklin & - & - & - & - & The event unclear \\
\hline 59 & Lake Gopło & & $\begin{array}{l}\text { Betula, Pinus, } \\
\quad \text { Quercus }\end{array}$ & $\mathrm{m}$ & Not recorded & $\begin{array}{l}\text { Alnus declined after the Carpinus decline, during } \\
\text { a moderate human impact phase }\end{array}$ \\
\hline 60 & $\begin{array}{l}\text { Lake } \\
\text { Kamionek }\end{array}$ & Fraxinus, Ulmus & $\begin{array}{l}\text { Betula, Pinus, } \\
\text { Quercus }\end{array}$ & 1 & $\begin{array}{l}\text { Decrease of Pediastrum, small rise of } \\
\text { Cyperaceae }\end{array}$ & $\begin{array}{l}\text { Al. declined after the Carpinus decline at the } \\
\text { beginning of a human impact phase; lowering } \\
\text { of the water table }\end{array}$ \\
\hline
\end{tabular}




\begin{tabular}{|c|c|c|c|c|c|c|}
\hline $\begin{array}{l}\text { Site } \\
\text { No. }\end{array}$ & Site Name & $\begin{array}{l}\text { Concurrent decline } \\
\text { in tree taxa }\end{array}$ & $\begin{array}{l}\text { Concurrent rise } \\
\text { in tree taxa }\end{array}$ & $\mathrm{HI}$ & $\begin{array}{l}\text { Changes in sediments and occurrence of local } \\
\text { ecosystem taxa (aquatic and mire organisms) }\end{array}$ & $\begin{array}{l}\text { Comment on environmental changes concurrent } \\
\text { with the Alnus decline }\end{array}$ \\
\hline 61 & $\begin{array}{c}\text { Lake } \\
\text { Skrzetuszewskie }\end{array}$ & - & - & - & & The event weakly expressed, unclear \\
\hline 62 & $\begin{array}{l}\text { Lake Lednica } \\
\text { I/86 }\end{array}$ & Ulmus & Salix & $\mathrm{m}$ & $\begin{array}{l}\text { Significant rise of Pediastrum and small } \\
\text { of Cyperaceae }\end{array}$ & $\begin{array}{l}\text { Alnus declined after the Carpinus decline, } \\
\text { concurrently with a moderate human impact phase }\end{array}$ \\
\hline 63 & $\begin{array}{c}\text { Lake } \\
\text { Głeboczek }\end{array}$ & Carpinus & $\begin{array}{l}\text { Salix, Betula, } \\
\quad \text { Pinus }\end{array}$ & 1 & Poor data & $\begin{array}{l}\text { The Alnus decline was concurrent with the very } \\
\text { beginning of a weak human impact phase }\end{array}$ \\
\hline 64 & $\begin{array}{l}\text { Lake } \\
\text { Świętokrzyskie }\end{array}$ & Carpinus & $\begin{array}{l}\text { Betula, } \\
\text { Populus, Salix }\end{array}$ & $\mathrm{m}$ & $\begin{array}{l}\text { Lithological limit: decrease of detritus gyttja, } \\
\text { increase of calcium carbonate; increase of } \\
\text { Thelypteris palustris, Filicales and } \\
\text { Nympheaceae; peak of Typha latifolia }\end{array}$ & $\begin{array}{l}\text { The Alnus decline was concurrent with } \\
\text { the beginning of a human impact phase; } \\
\text { lowering of the lake water table }\end{array}$ \\
\hline 65 & Lake Baba & - & - & - & $\therefore$ & The event weakly expressed, unclear \\
\hline 66 & Giecz 4/90 & Fraxinus & $\begin{array}{l}\text { Betula, Salix, } \\
\text { Populus }\end{array}$ & 1 & $\begin{array}{l}\text { Strong lithology change: layer of sand; decrease } \\
\text { of Pediastrum and a rise of Cyperaceae }\end{array}$ & $\begin{array}{l}\text { Alnus declined after the Carpinus decline } \\
\text { at an early human impact phase; hydrological } \\
\text { disturbances at the event }\end{array}$ \\
\hline 67 & Lake Wonieść & Quercus, Ulmus & Betula, Pinus & 1 & No data & $\begin{array}{l}\text { Alnus declined after the Carpinus decline, during } \\
\text { an advanced, moderate human impact phase; } \\
\text { slight decline of anthropogenic indicators }\end{array}$ \\
\hline 68 & $\begin{array}{l}\text { Lake Paklicko } \\
\text { Wielkie }\end{array}$ & Quercus & Pinus, Betula & $\mathrm{m}$ & Local hydrology change not recoded & $\begin{array}{l}\text { Alnus declined after the Carpinus and Fagus } \\
\text { declines; the decline of a human impact phase }\end{array}$ \\
\hline 69 & Lake Długie & Quercus & Betula, Pinus & $\mathrm{m}$ & Local hydrology change not recoded & $\begin{array}{l}\text { Alnus declined after the Carpinus and Fagus } \\
\text { declines during a moderate human impact phase; } \\
\text { slight decline of anthropogenic indicators } \\
\text { at the Alnus minimum }\end{array}$ \\
\hline
\end{tabular}



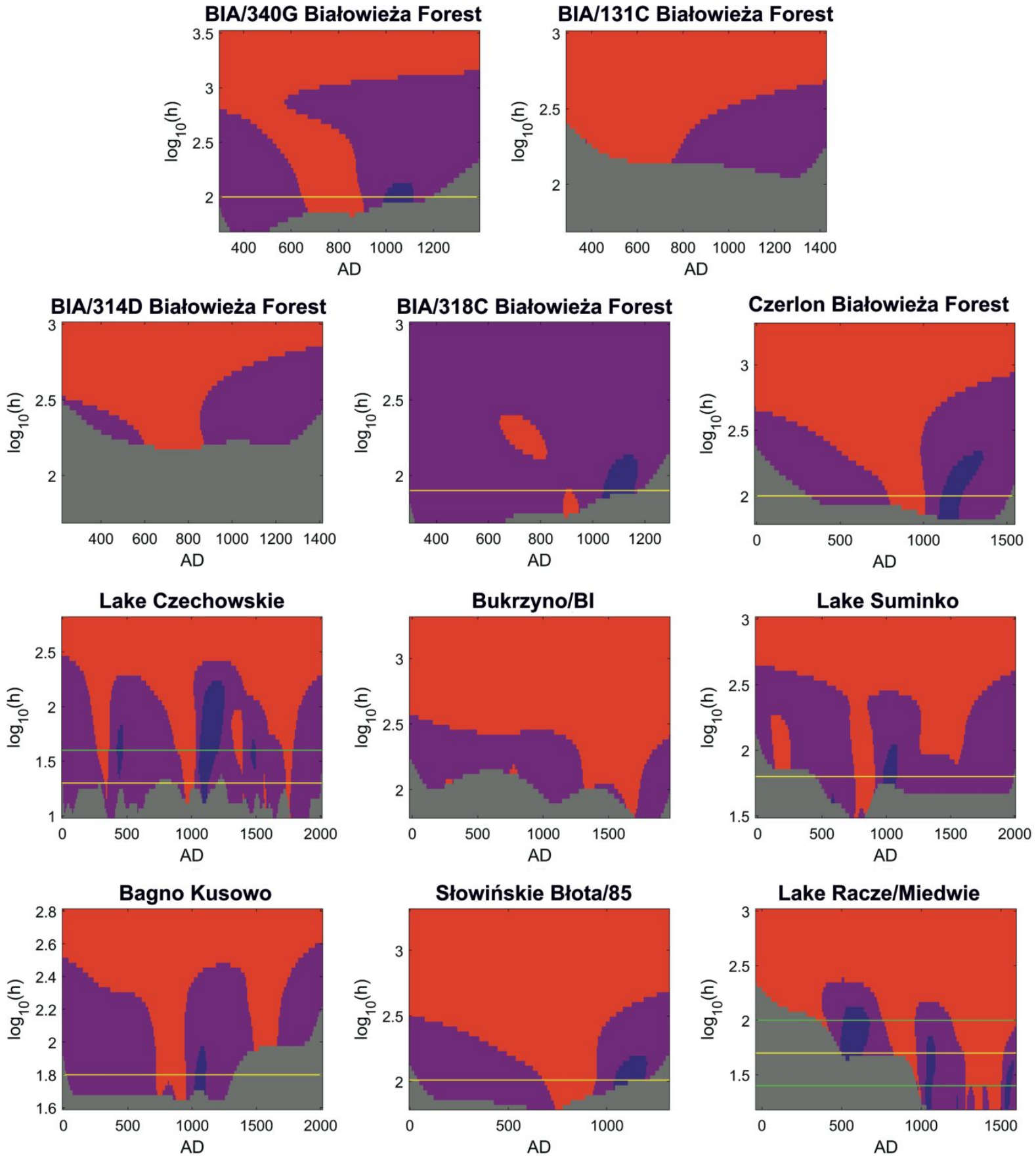

ESM Figure S1 The results of the SiZer analyses of Alnus pollen curves in selected sites in Poland (for site information, see the caption of Fig. 4 in the main text). In the maps, the horizontal axis represents the time, the vertical axis represents the scale and the colour of each pixel represents the significance of the derivative of the smooth of the curve at the corresponding time and scale. Red, blue and purple indicate that the derivative is significantly negative, positive or neither, respectively. Grey means that the data are too sparse for inference. The most suitable scales for the detection of the significant decline-rise events in the data are shown with vertical lines. The scale that reveals the decline-rise event at the end of the first millennium is shown with a yellow line, and the scales for the other events are shown with green lines 